\title{
Adaptations of pyrophilous insects to burnt habitats: Odor signals, infrared receptors and behavior
}

In partial fulfillment of the requirements for the degree of Doctor of Philosophy (PhD) of the Faculty of Forest Sciences and Forest Ecology, University of Göttingen, Germany

\author{
Submitted by \\ Thi Phuong Hoang \\ Born in Thanh Hoa, Vietnam \\ Göttingen, July 2019
}


$1^{\text {st }}$ reviewer: Prof. Dr. Carsten Mai

$2^{\text {nd }}$ reviewer: PD. Dr. Helmut Schmitz

Date of oral examination: 22.10.2019 


\section{Acknowledgements}

I am deeply grateful to the KAAD, which provided the financial support for this study. My great thanks also go to my former supervisor Prof. Dr. Stefan Schütz and my new supervisors Prof. Dr. Carsten Mai, PD Dr. Helmut Schmitz and Dr. Gerrit Holighaus for their supervision, support and advice. Also, I would like to thank Prof. Dr. Michael Rostás for the evaluation of my oral examination. I am indebted to Andreas Teichmann for his help in constructing the infrared traps.

Further thanks go to all of the present and former staff of the department of forest zoology and forest protection, who helped me during my research. Thank you very much: Dr. Bernhard Weissbecker, Dr. Martin Gabriel, Christine Rachow, Sara Nicke, Ulrike Eisenwiener, Dr. Heinrich Lehmann-Danzinger, Yadanar Oo and Dr. Karthi Balakrishnan. Prof. Dr. Stefan Schütz provided ideas for the concept of the study. Further thanks go to specialists of the Department of Insect Systematics at the Institute of Biology and Ecological Resources, Hanoi, Vietnam for their identification of insects, and all of the Vietnamese students and workers who contributed to my work during field data collection in Vietnam.

I would like to thank my husband, Daniel Jestrzemski for his help for the correction of the English-German translation and proofreading, establishing a figure in chapter 4 and his correction of the references of the whole thesis. Moreover, thanks to my husband, my son Nico Jestrzemski, and my both German and Vietnamese families for giving sense to my life. Without their support, I would not have been be able to finish my research. 


\begin{abstract}
Pyrophilous insects are known to invade recently burnt habitats for food, mating and oviposition. They can approach fires due to their ability to recognize fire-specific volatile organic compounds (VOCs). Moreover, some of these insects also possess infrared (IR) receptors to detect fires and hot surfaces. The aim of this thesis is to examine recently burnt habitats for the presence of pyrophilous insects and identify cues suitable for them to find burnt habitats. This includes morphological and chemo-ecological studies unravelling the significance of IR receptors, IR radiation, volatile signals and behavior.

Three major questions were selected to investigate how pyrophilous insects approach fires: 1) identify fire-specific VOCs that are released by different Vietnamese plant species and are suitable cues for pyrophilous insects, 2) testing the behavioral responses of pyrophilous insects to volatile and heat (IR radiation) stimuli, and 3) identifying the sensory adaptation of the pyrophilous flat bug Aradus candidatus found to be active in recently burnt habitats. Volatile analysis (gas chromatography - mass spectrometry) was used to identify fire-specific VOCs to be subsequently tested in the field for their ability to influence insect behavior. Electroantennography (EAG) was used to examine the perception of pyrophilous insects to these VOCs. With a scanning electron microscope (SEM), pyrophilous insects were examined for presence of IR receptors. The results were used to conclude how pyrophilous insects are adapted to recently burnt habitats.

The trace analysis presented in chapter 3 of this thesis resulted in the detection of 55 VOCs that were released by four different Vietnamese plant species. Four of these VOCs identified as fire-specific were further tested in a behavioral field study. They derive from cellulose (hydroxyacetone, 5-methylfurfural) and lignin (guaiacol and 4-ethylguaiacol) degradation. Traps in a freshly burnt habitat baited with a mixture of these VOCs attracted 13 insect species belonging to the order Coleoptera that were not found in control traps positioned on adjacent unburnt land. Three of these were additionally found by hand collections, where another eight species of insects were found. The biodiversity of plant species seems to be associated with the chemo-diversity of fire-induced VOCs. This might play an important role for pyrophilous insects, thus linking plant diversity to the biodiversity of pyrophilous insects.

The attraction of pyrophilous insects to IR and volatile stimuli is investigated in chapter 4. A total of 26 insect species were recorded. The attraction of pyrophilous insects towards firespecific VOCs, IR and combined stimuli was significantly higher when compared to the controls. One species (Litochrus sp. 1, Phalacridae, Coleoptera) was found in traps of all
\end{abstract}


combinations. Fungivorous insects were caught significantly more often in the IR traps, whereas VOC traps attracted carnivorous insects significantly more often. All traps attracted herbivorous insects. Eight insect species were caught in more than one trap. Among them, only one species was caught in all traps. Two species belonging to the family Cleridae (Coleoptera) were caught in different traps: while Anthicoclerus sp. 1 was recorded exclusively in the IR trap also containing the VOCs mixture, Anthicoclerus sp. 2 was trapped only in the IR trap without VOCs. These results hint at a complex evaluation of IR and olfactory stimuli for resource location by different members of the pyrophilous insect community.

The study on adaptation and behavior of A. candidatus in chapter 5 showed that A. candidatus elicits olfactory responses in electroantennograms (EAG) to hydroxyacetone, 5-methylfurfural, guaiacol, 4-methylguaiacol and 4-ethylguaiacol. Additionally, A. candidatus shows attraction to the traps baited with a mixture of fire-specific VOCs. Aradus candidatus also elicits a dose response to three other VOCs: Nonanal, 3-octanone and $2(5 \mathrm{H})$-furanone. In morphological studies, IR receptors were found in the propleural region of $A$. candidatus. These IR receptors have an outer shape similar to other species of the genus Aradus, including A. albicornis, A. lugubris and A. fuscicornis. The results of this chapter illustrate that pyrophilous insect species equipped with IR receptors show a highly pyrophilous behavior.

The results from these three studies show that pyrophilous insects can detect fire-specific VOCs, which helps them to approach fires. However, not all insects that are able to perceive a single fire-specific VOC are necessarily pyrophilous. A mixture of different fire-specific VOCs is recommended for testing the attraction of pyrophilous insects to fires. By attraction to both fire-specific VOCs and IR, some insect species revealed their distinct pyrophilous behavior. This was confirmed by demonstrating VOC and IR detection in A. candidatus on a morphological and physiological level. 


\section{Zusammenfassung}

Feuerliebende Insekten besiedeln frisch niedergebrannte Lebensräume zur Nahrungsaufnahme, Fortpflanzung und Eiablage. Bei der Suche nach Brandflächen hilft ihnen ihre Fähigkeit, feuerspezifische, flüchtige organische Verbindungen (VOCs) wahrzunehmen. Manche Arten besitzen Infrarotrezeptoren, um Feuer und heiße Oberflächen aufzuspüren.

Das Ziel dieser Dissertation ist es, das Vorkommen von pyrophilen Insekten in kürzlich niedergebrannten Naturflächen in Vietnam zu untersuchen und Duftstoffe zu identifizieren, die ihnen helfen, diese zu finden. Die Arbeit umfasst eine morphologische und chemoökologische Studie, mit der die Bedeutung von Infrarotrezeptoren, Infrarotstrahlung und flüchtigen organischen Signalen und sowie des Verhaltens pyrophiler Insekten untersucht werden soll. Hieraus ergeben sich drei grundlegende Forschungsziele:

1) Identifikation von feuerspezifischen VOCs, die von verschiedenen vietnamesischen Pflanzenarten emittiert werden und geeignete chemische Reize für feuerliebende Insekten darstellen.

2) Untersuchung der Verhaltensreaktion von feuerliebenden Insekten auf Stimuli von VOCs und Hitze (Infrarotstrahlung).

3) Untersuchung der sensorischen Adaption der feuerliebenden Rindenwanze Aradus candidatus an kürzlich niederbrannte Lebensräume.

Die feuerspezifischen VOCs wurden mittels Gaschromatographie-Massenspektrometrie (GCMS) analysiert. Anschließend wurde in Feldversuchen ihre Fähigkeit untersucht, das Flugverhalten von Insekten zu beeinflussen. Mittels Elektroantennographie (EAG) wurde die Wahrnehmung von VOCs durch pyrophile Insekten getestet, während das Vorhandensein von möglichen Infrarotrezeptoren auf den Insektenkörpern durch Rasterelektronenmikroskopie (REM) überprüft wurde. Aus den Ergebnissen wurden Schlussfolgerungen über die Anpassung von feuerliebenden Insekten an kürzlich niedergebrannte Habitate gezogen.

Durch die im dritten Kapitel präsentierte Spurenanalyse (GC-MS) wurden 55 feuerspezifische VOCs nachgewiesen, die von vier verschiedenen vietnamesischen Pflanzenarten emittiert werden. Vier dieser VOCs wurden als Stimuli im Feld im Rahmen einer Verhaltensstudie getestet. Die getesteten Duftstoffe basieren auf dem Abbau von Zellulose (Hydroxyaceton, 5Methylfurfural) und Lignin (Guaiacol und 4-Ethylguaiacol) und wurden für die Feldversuche in Ködern in frisch niedergebranntem sowie intaktem Kontrollhabitat in Zentralvietnam während der Trockenzeit ausgehängt (2014 und 2015). Dreizehn Insektenarten in der Ordnung Coleoptera kamen ausschließlich in abgebranntem Habitat vor. Acht Arten wurden zudem auf 
glimmenden Holzresten im gleichen Habitat nachgewiesen. Die Biodiversität von Pflanzenarten scheint in Verbindung mit der Chemodiversität von feuerinduzierten VOCs zu stehen, was auf eine Korrelation zwischen Pflanzendiversität und der Vielfalt von feuerliebenden Insekten schließen lässt.

In Kapitel 4 wird die Anziehung von pyrophilen Insekten zu volatilen und Infrarotstimuli untersucht. In den mit Infrarotstrahlung und feuerspezifischen VOCs bestückten Köderfallen wurden insgesamt 36 Insektenarten erfasst. Diese Köderfallen waren signifikant attraktiver für feuerliebende Insekten als die nicht bestückten Kontrollfallen.

Eine Insektenart (Coleoptera, Phalacridae, Litrochus sp. 1) wurde sowohl in den Köderfallen als auch in den Kontrollfallen auf verbranntem Gebiet gefangen. Pilzfressende Insekten wurden signifikant häufiger in den Infrarotfallen gefangen, während VOCs-Fallen signifikant attraktiver für fleischfressende Insekten waren. Alle Fallen waren attraktiv für herbivore Insekten. Acht Insektenarten wurden in mehr als einem Fallentyp gefangen.

Von diesen kam nur eine Insektenart in allen Fallen vor. Zwei Arten aus der Familie Cleridae (Coleoptera) zeigten unterschiedliche Fallenpräferenzen: während Anthicoclerus sp. 1 ausschließlich in der Infrarotfalle mit der VOCs-Beköderung auftauchte, fand sich Anthicoclerus sp. 2 stets nur in der Infrarotfalle ohne die VOCs-Beköderung. Diese Resultate lassen auf eine komplexe Wirkungsweise der olfaktorischen und Infrarotstimuli für das Lokalisieren von Nahrungsressourcen durch verschiedene Mitglieder der feuerliebenden Insektengemeinschaft schließen. Die Untersuchung von Adaption und Verhalten von $A$. candidatus mittels EAG (Kapitel 5) ergab, dass Hydroxyaceton, 5-Methylfurfural, Guaiacol, 4-Methylguaiacol und 4-Ethylguaiacol bei der Art eine olfaktorische Reaktion hervorrufen.

Zudem zeigt A. candidatus eine Anziehung hin zu einer Mischung aus verschiedenen feuerspezifischen VOCs. Drei weitere VOCs riefen bei den EAG-Versuchen ebenfalls eine olfaktorische Reaktion hervor: Nonanal, 3-Octanon und 2(5H)-Furanon.

In den morphologischen Studien wurden Infrarotrezeptoren in der propleuralen Region von $A$. candidatus nachgewiesen. Diese Rezeptoren ähneln in ihrer Form denen von anderen Arten der Gattung Aradus, darunter A. albicornis, A. lugubris und A. fuscicornis. Die Ergebnisse dieses Kapitels deuten darauf hin, dass feuerliebende Insekten mit Infrarotrezeptoren ein stark pyrophiles Verhalten aufweisen.

Die drei Studien zeigen, dass pyrophile Insekten feuerspezifische VOCs wahrnehmen können, was ihnen beim Lokalisieren und Anfliegen von Bränden hilft. Dennoch sind nicht alle Insekten, die einzelne feuerspezifische VOCs wahrnehmen können, zwingend pyrophil.

Daher sollte die Anziehung von pyrophilen Insekten zu Bränden mit Hilfe einer Mischung aus feuerspezifischen VOCs getestet werden. Einige Arten, die sowohl von feuerspezifischen 
VOCs als auch von Infrarotstrahlung angezogen werden, zeigen ein deutlich pyrophiles Verhalten. Dies wird durch die Fähigkeit zur Detektion von VOCs und Infrarotstrahlung durch A. candidatus auf morphologischer als auch physiologischer Ebene bestätigt. 


\section{Table of contents}

Acknowledgements.................................................. I

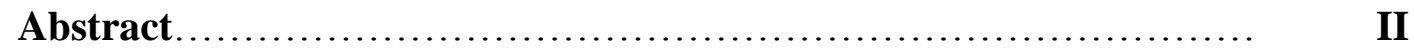

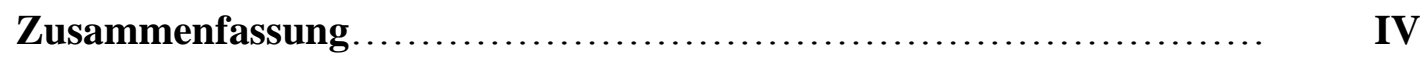

Table of contents..................................................... VII

\section{Chapter 1:}

Adaptation of pyrophilous insects to burnt habitats: General introduction 1

1.1 Introduction ............................................ 1

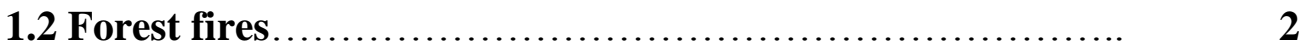

1.3 Pyrophilous insects.................................... 5

1.4 Infrared receptors in insects............................ 5

1.5 Volatile organic compounds................................ 6

1.6 Roles of VOCs for insects................................... 7

1.7 Formation of VOCs.......................................... 8

1.8 Carbohydrate polymers................................. 9

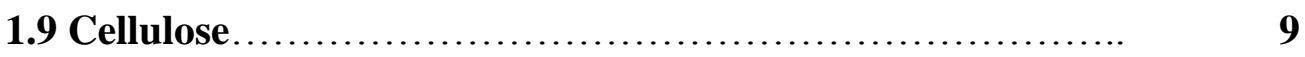

1.10 Lignin ..............................................

1.11 Objectives of this thesis................................

1.12 References.............................................

Chapter 2:

Pyrophilous insects in Vietnam Central Highlands.................... 22

Abstract ....................................................

2.1 Introduction ............................................

2.2 Study site and experimental design ......................

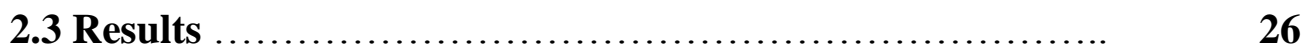

2.4 Discussion ................................................

2.5 Acknowledgements.................................... $\quad 30$

2.6 References.............................................

\section{Chapter 3:}

Do volatiles released upon heating of different species of Vietnamese woody plants attract pyrophilous insects? 


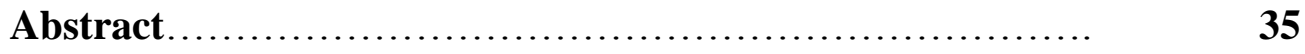

3.1 Introduction .......................................... 36

3.2 Materials and methods $\ldots \ldots \ldots \ldots \ldots \ldots \ldots \ldots \ldots \ldots \ldots \ldots, \quad 37$

3.2.1 Wood samples................................ 37

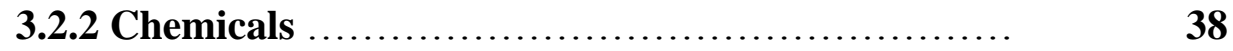

3.2.3 Sampling of volatiles.......................... $\quad 38$

3.2.4 Trace analysis ................................. 38

3.2.5 Hand collection.................................

3.2.6 Field tests........................................

3.2.7 Statistical analysis............................. 41

3.3 Results............................................ 41

3.3.1 Trace analysis................................ 41

3.3.2 Field trial results............................... 43

3.4 Discussion ......................................... 45

3.4.1 Burnt wood volatiles............................

3.4.2 Field tests.................................... 46

3.4.3 Links between burnt wood volatiles and the biodiversity of pyrophilous insects................................. 47

3.5 Conclusion $\ldots \ldots \ldots \ldots \ldots \ldots \ldots \ldots \ldots \ldots \ldots \ldots \ldots \ldots \ldots \ldots, \quad 47$

3.6 Acknowledgements................................. 48

3.7 References.......................................... 49

\section{Chapter 4:}

Pyrophilous insects respond to different stimuli.................. 51

Abstract ................................................ $\quad 52$

4.1 Introduction ......................................... 53

4.2 Materials and methods................................ 54

4.2.1 Trap construction.............................. $\quad 54$

4.2.2 Estimation of the trapping radius of the trap emitting IR radiation............................................ $\quad 55$

4.2.3 Estimation of the trapping radius of the trap baited VOCs. 
4.2.4 Chemicals.................................... $\quad 56$

4.2.5 Study area and experimental design............... $\quad 56$

4.2.6 Statistical tests............................... 57

4.3 Results............................................... 57

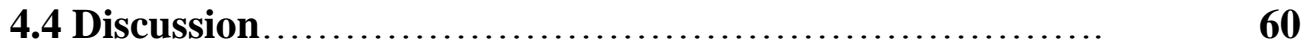

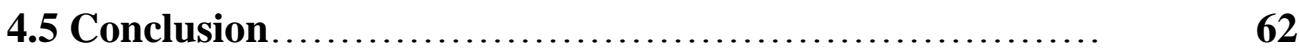

4.6 Acknowledgements..................................... 62

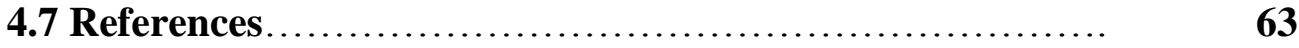

\section{Chapter 5:}

Behavioral and sensory adaptations of the flat bug Aradus candidatus to post-fire habitats in Vietnam................................... 65

Abstract .................................................. $\quad 66$

5.1 Introduction ........................................... 67

5.2 Materials and Methods................................ $\quad 68$

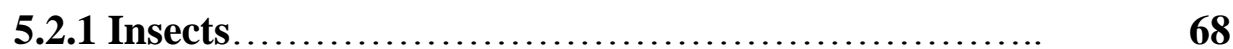

5.2.2 Chemicals......................................... $\quad 68$

5.2.3 EAG experiments.................................

5.2.4 Trap construction..............................

5.2.5 Field traps $\ldots \ldots \ldots \ldots \ldots \ldots \ldots \ldots \ldots \ldots \ldots \ldots \ldots \ldots ., \quad 70$

5.2.6 Scanning electron microscopy $(\mathrm{SEM}) \ldots \ldots \ldots \ldots \ldots \ldots . . \ldots$

5.2.7 Data analysis..................................

5.3 Results...............................................

5.3.1 Attraction to different types of traps on burnt areas 72

5.3.2 EAG responses of $A$. candidatus antennae to fire-specific volatile organic compounds.......................... 73

5.3.3 Propleural IR receptors......................... $\quad 74$

5.4 Discussion........................................ 76

5.4.1 Attraction to a mixture of fire-specific VOCs........ 76

5.4.2 Structure and functions of IR receptors............ 78

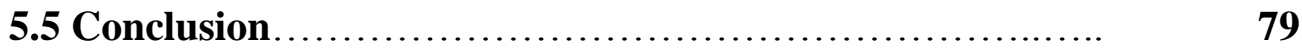

5.6 Acknowledgements................................. $\quad 80$ 


\section{Chapter 6:}

Adaptation of pyrophilous insects to burnt habitat: General discussion and conclusion.

6.1 Presence of pyrophilous insects in Vietnam.

6.2 Diversity of VOCs and insects in recently burnt habitats (chapter 3)

6.3 Are burnt wood VOCs a cue for pyrophilous insects to find burnt habitat?

6.4 Is infrared radiation a cue for pyrophilous insects to find burnt habitats? (Chapter 4)

6.5 Attraction of insects in recently burnt habitats to VOCs, infrared stimuli or both stimuli.

6.6 Is multimodal sensing important for the behavior of pyrophilous insects? Hints from $A$. candidatus (chapter 5)

6.7 Conclusion

6.8 References. 


\section{Chapter 1 \\ Adaptation of pyrophilous insects to burnt habitats: General introduction}

\subsection{Introduction}

Natural fires have great impact on the human environment and ecological niches, altering the living conditions for plants, animals and fungi (Wikars 1997). Fire is a strong selective force for the best adaptation abilities to survive in these fire-altered habitats. Consequently, successfully adapted species become prevalent especially after fires and may also spread (Grimaldi \& Engel 2005; Linksvayer et al., 2012). Some insect species are attracted to flames or smoke, which indicate fire and thus an availability of crucial resources for oviposition and food (New 2014). These species are defined as pyrophilous (Greek for fire-loving), since they significantly depend on forest fires for their reproduction. When a fire occurs, they approach and invade the burnt area immediately afterwards (Wikars 1997; Klocke et al., 2011). Since pyrophilous insects are primarily decomposers, they may profit from the increased nutrient availability after forest fires (Wikars 1997). However, it is unclear whether a warmer microclimate, reduced competition or fire-created substrates such as burnt wood are the crucial factor for their survival (Wikars 2002). Well-known pyrophilous insect species include members of the order Coleoptera (e.g., saproxylic species such as the buprestid beetle Melanophila acuminate), but also of other orders including Diptera (New 2014).

The adaptation of pyrophilous insects to a newly burnt habitat requires specially adapted motoric abilities such as crawling or flying. At the same time, the insects use olfactory and visual senses, in particular infrared (IR) perception, to detect smoke and find suitable food sources or mating partners while avoiding contact with hot surfaces remaining from fire (Nation 2001; Grimaldi \& Engel 2005). Equipped with these abilities and sensory modalities, insects must decipher relevant cues to find a suitable habitat. This can be visual orientation toward a host plant species (Briscoe \& Chittka 2001), acoustic and olfactory orientation towards a mating partner (Groot et al., 2010) and olfactory orientation towards a food source (Vogt \& Riddiford 1981; Singh 1998). Many insect species rely on olfaction as an essential sense for orientation within and towards their ecological niches (Hansson 1999). Olfaction is based on the perception of Volatile Organic Compounds (VOCs) or VOC profiles to discriminate between healthy or damaged plants (Schütz et al., 1997a, 1997b; Schütz \& Weißbecker 2003; Weißbecker 2004), to communicate with each other (Pelosi \& Maida 1995), or in case of pyrophilous insects to find freshly burnt habitats (Schütz et al., 1999a, 1999b). 
Volatile organic compounds are produced by different sources. For example, they can be byproducts or end-products of the plant metabolism (Schütz et al., 1997b) or released intentionally by insect species (Vogt \& Riddiford 1981). For example, plants release sesquiterpenes at at room temperature $\left(23 \pm 2^{\circ} \mathrm{C}\right)$ (Manninen et al., 2002), due to drought stress or autooxidation (Choe and Min 2005) and may induce VOCs for defense (Schöning et al., 1998; Thakeow et al., 2008). Besides organic matter, forest fires release high amounts of VOCs. During such fires, the degradation process of hemicellulose, cellulose and lignin, the essential compartments of a woody plant species, takes place.

For finding food sources, insects use olfaction both alone and in combination with other senses to maximize the efficiency (Schmitz et al., 2002; Heisswolf et al., 2007). Several pyrophilous insect species use the combination of senses for orientation towards newly burnt areas, including the beetle Acanthocnemus nigricans (Schmitz et al., 2002; Kreiss et al., 2007) and buprestid beetles of the genus Melanophila (Evans 1964; Schmitz et al., 1998; Schmitz et al., 2007). These pyrophilous insects are attracted to smoke produced by smoldering logs (Schütz et al., 1999a, 1999b; Paczkowski et al., 2013). Besides olfactory receptors, they possess also IR receptors (Schmitz et al., 2002; Kreiss et al., 2007). The interactions between olfaction and other types of perception in pyrophilous insects are complex. The question arises how pyrophilous insects can efficiently use visual, IR and olfactory perception for the detection of suitable habitats. This is a fundamental, yet unanswered question that should give occasion for studies on the behavior of pyrophilous insects in different regions of the world.

In large areas of Vietnam, forest fires take place very frequently (Le et al., 2014). They can be caused by natural events or anthropogenic actions (McNamara et al., 2006) and frequently attract pyrophilous insects (Hoang \& Schütz 2015; Geiser 2016). Studies of pyrophilous insects in Vietnam are scarce. However, the presence of pyrophilous insects, their behavior and adaptation to recently burnt habitats in Vietnam are an important aspect for the understanding of tropical forest ecology and forest fire management. Hence, this gave rise to investigate the occurrence and adaptation of pyrophilous insects in the recently burnt habitats in Vietnam Central Highlands.

\subsection{Forest fires}

Forest fires are natural events which have a high impact on the ecological niches and forest fauna and flora. They impact the forest ecosystem both negatively and positively.

Fires in forests are usually more disastrous than those in other habitats because of the large volumes of burnt plant biomass and the rapid spread of the flames. Forest fires burn whole trees or some parts of the tree like the roots, bole or crown. This often leads to tree mortality 
after fires (Swezy \& Agee 1991). Therefore, Forest fires cause damage to the habitat and ecosystem and - initially - can be regarded as a threat to biodiversity (Swengel 2001).

On the other hand, forest fires positively impact the ecosystem and biodiversity by establishing between-patch heterogeneity (Levin \& Paine 1974; Picket \& White 1985) of the habitat after forest fires. This will increase the differences in stand structures and composition of tree species (Wright \& Bailey 1982; Danks \& Footit 1989; Esseen et al., 1992).

Moreover, fire affects the different layers (litter, herbs, shrubs and canopy) and forest types differentially (Prodon et al., 1987). Therefore, fires also alter the diversity of insect communities within these habitats. Effects of fires on the ecosystem and to the diversity of insects depend on the type of fires (e.g., wildfires) or fire management (e.g., prescribed burning). In 2010, Vietnam's forests covered 13,258,843 ha (39.1\% of the total land area), of which $10,339,305$ ha were natural forests $(82.7 \%)$ and $2,919,538$ ha of forest plantations (17.3\%) (FPD Vietnam 2010). During the dry season, there are about six million hectares (ha) of forest with high potential of forest fire risk (about $50 \%$ of Vietnam's total forest area), located in 48 different provinces. Vegetation types particularly susceptible to fires include forest stands of pines, dipterocarps, casuarinas, eucalyptus and bamboo, as well as other types of land cover such as grass- and shrublands (Hoang 2007). In the face of global climatic changes, weather extremes in Vietnam are likely to become more severe and abundant, which could significantly increase the frequency of forest fires. With shortened rainy seasons, fires could take place throughout the year in different provinces, depending on the weather and climatic condition of each location.

Forest fires happen all over Vietnam during different annual periods (see Fig. 1). From December to April, regions with high forest-fire risk include North Vietnam, Southeastern Vietnam, Vietnam Central Highlands and the Mekong River Delta, whereas from April to June, forest fires occur in the coastal provinces of Central Vietnam. From June to August, hot and dry west winds cause forest fires in the north of Central Vietnam (Hoang 2007). 

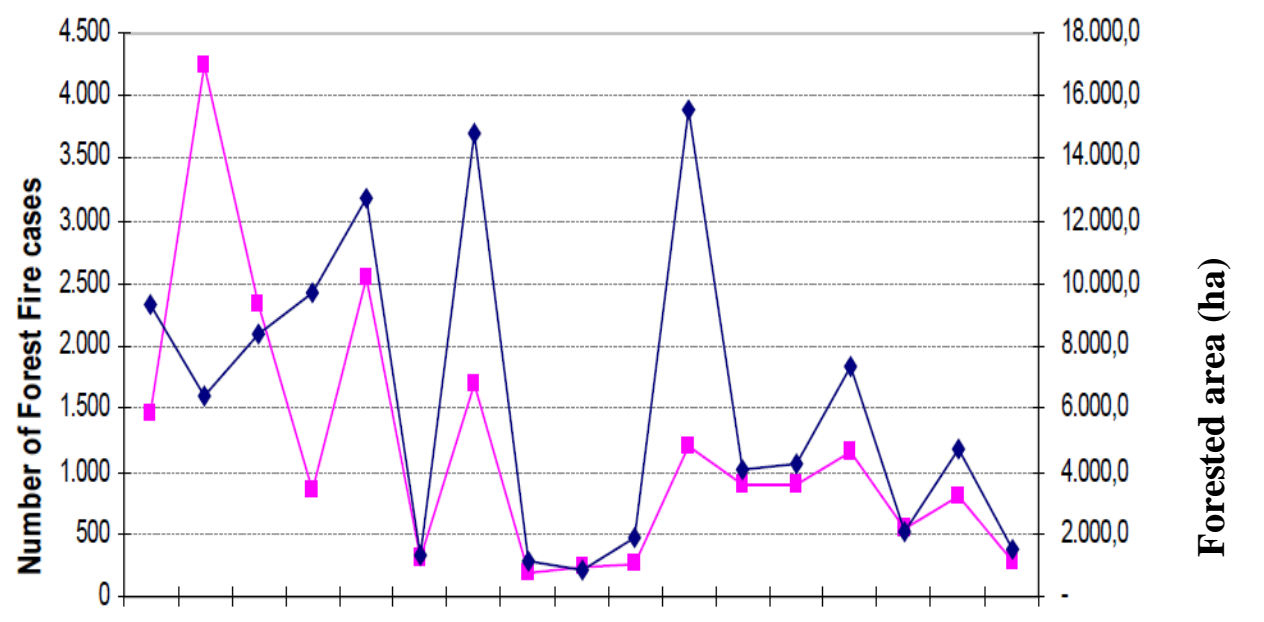

19921993199419951996199719981999200020012002200320042005200620072008

Figure 1: Forest fire data, pink: Forest fired cases and Lila: forest fire area (FPD Vietnam 2007).

There is a strong correlation between the number of forest fires in Vietnam and El Niño-Southern Oscillation (ENSO) activities. Vietnam Central Highlands are considered to be hotspots of forest fires, since they experience the longest dry season of any region in the country (from October to March). Provinces specifically affected by forest fires are Gia Lai, Dak Lak, Dak Nong, Kon Tum and Lam Dong (Fig. 2).

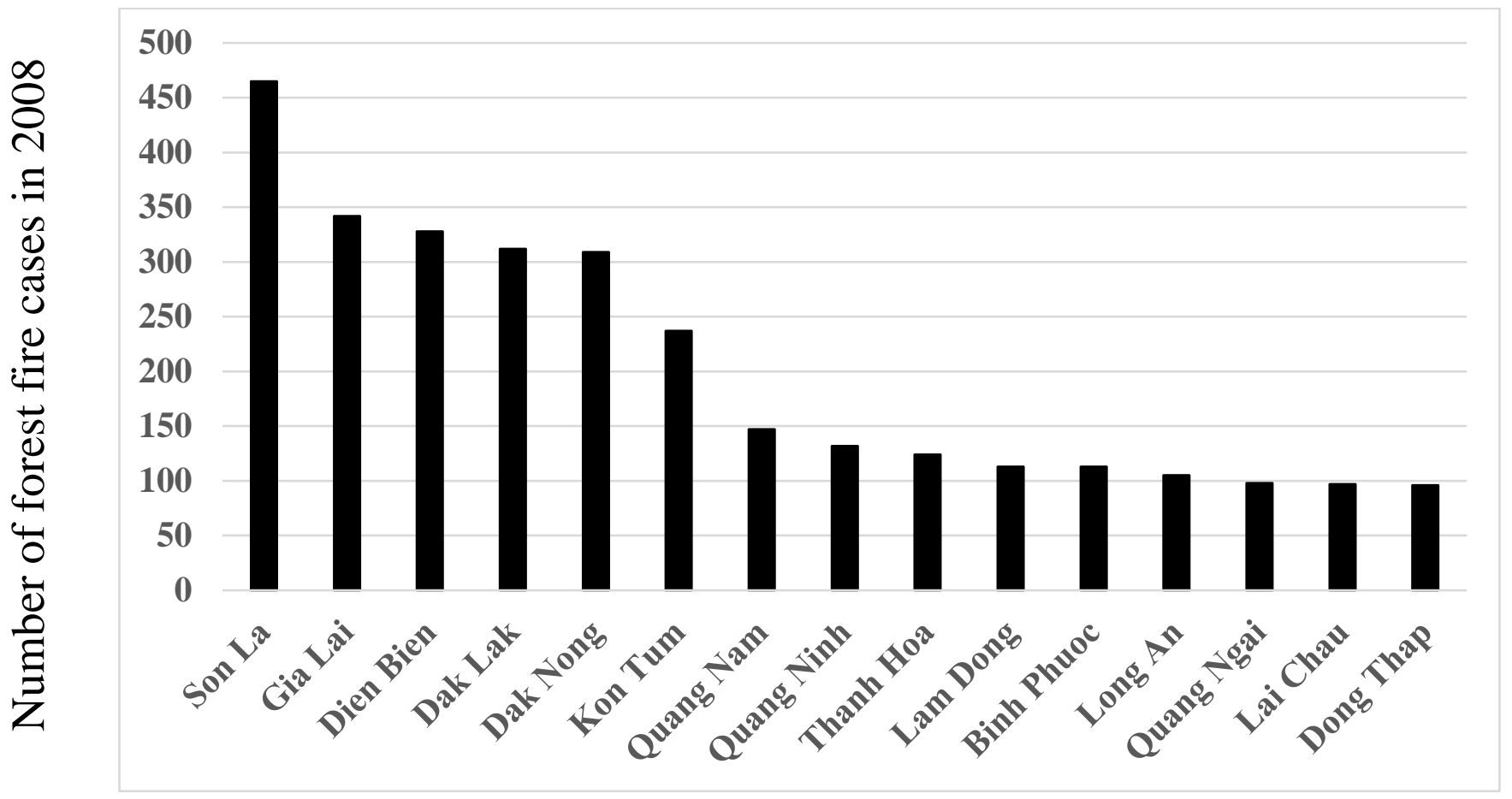

\section{Provinces of Vietnam}

Figure 2: Forest fires in Vietnam Central Highlands (FPD Vietnam 2008). 


\subsection{Pyrophilous insects}

Organisms which benefit from fire-affected forests as habitats or actively select such habitats are known as "pyrophilous" or "fire-loving". Pyrophilous organisms are known among plants, fungi, and animals, including numerous insects in the orders Hemiptera, Lepidoptera, Diptera and Coleoptera from at least 25 families (Klocke et al., 2011). In contrast to non-pyrophilous insects, populations of pyrophilous insects decline dramatically after fires, while their population richness immediately regains after a fire (Swengel 2001). Fire-loving insects need forest fires for their reproduction. Consequently, they approach fires and invade the burnt area immediately. In order to navigate towards a fire, as well as for orientation on the freshly burnt surface, pyrophilous insects use distinct sensors for burnt plant odor and maybe infrared (IR) radiation. Some beetles feature IR sensors underneath their wings (Schmitz et al., 1998), while others have antennae with smoke sensors perceiving the scent of smoke (Schütz et al., 1999a). Correlations between the biodiversity of pyrophilous insects and ecological disturbances such as fires have been studied extensively by researchers (Muona \& Rutanen 1994; Wikars 1997). Recently, interest in the behavior of pyrophilous insects, their interaction with forest fires, and on the effects of fire on their population dynamics has grown. Also, military scientists have been focusing on the sensors of these insects and their ability to detect IR radiation. Forest fires can both result in decreased or increased insect damages to forest trees (Swengel 2001). However, the outcomes depend on the intensity of the fire as well as on the tree and insect species involved. For example, attacks of certain pest insects may cause such severe forest damages that large amounts of deadwood are produced, providing for combustibles that facilitate future fire outbreaks (Geiszler et al., 1980).

\subsection{Infrared receptors in insects}

Infrared radiation plays an important role for several living organisms. Besides the needs of long wave IR radiation for thermoregulation (Schmitz et al., 1997), some animals use high sensitivity IR receptors for effectively ambushing their prey, like in rattlesnakes and boid snakes (Bullock \& Cowles 1952; Bullock \& Fox 1957). Nocturnally active snakes use their IR receptors for detecting prey at night (Gamow \& Harris 1973). IR receptors also are essential tools to help blood-sucking insects like Chagas bugs to detect and steer toward their preys (Lazzari \& Nunez 1989).

Infrared receptors are found in some pyrophilous insects. It has been speculated that receptors are used for detecting forest fires. There is a strong evidence that buprestid beetles of the genus Melanophila approach forest fires (Champion 1909; Nicholson 1919; Linsley 1943; Evans 1962, 1964; Apel 1988, 1989). These beetles perceive IR radiation with their thoracic IR 
receptors (Evans, 1964; Schmitz et al., 2000). The Australian fire beetle Merimna atrata is known to detect fires from far distances (Poulton 1915; Schmitz et al., 2002). This species has two pairs of IR organs on the ventrolateral sides of the abdomen (Schmitz et al., 2000). The "Little Ash" beetle Acanthocnemus nigricans (family Acanthocnemidae) approaches forest fires (Champion 1922). A. nigricans possesses IR receptors on the prothorax (Schmitz et al., 2002). Several species of flat bugs (Heteroptera: Aradidae) are found frequently at burnt sites (Hjältén et al., 2006). Various Aradus species are attracted by the open fire, hot ash, or smoke such as A. albicornis, and A. lugubris (Wikars 1997). The IR receptors have been found in A. albicornis (Schmitz et al., 2008), and also in A. lugubris, A. flavicornis, and A. fuscicornis (Schmitz et al., 2010).

The IR receptors are located on different parts of the body in the mentioned insect species. In Melanophila beetles, one pair of IR pit organs are located on the metathorax adjacent to the coxae of the middle legs (Evans 1966). Two pairs of IR organs in M. atrata are situated ventrolaterally on the abdomen (Schmitz et al., 2000). Differently, the first thoracic segment is the site where complex IR receptor organs in A. nigricans can be found. Unlike the three species above, IR receptors of several Aradus bugs (A. lugubris, A. albicornis, A. flavicornis, and A. fuscicornis) are located at the bases of the pro- and mesothoracic legs and on the lateral areas of the propleurae (Schmitz et al., 2010).

The morphological similarities and differences of IR receptors in pyrophilous insects suggest similarities but also differences in the functions of these organs. Regarding the functional principle, the IR receptors of Merimna atrata have been described to be similar to the $A$. nigricans receptors (Schmitz et al., 2002). Because of the similarity in morphology between the Aradus sensillum and the IR receptors of buprestid beetles in the genus Melanophila, it can be proposed that the function of IR receptors in these species are comparable (Schmitz et al., 2007; Vondran et al., 1995).

\subsection{Volatile Organic Compounds}

Volatile organic compounds (VOCs) are referred to as organic chemical compounds which have a vapor pressure of $1013 \mathrm{hPa}$ at SATP (Standard Ambient Temperature and Pressure) conditions at $25^{\circ} \mathrm{C}$. These SATP conditions are necessary to let organic chemical compounds evaporate into the gaseous phase. Volatiles can be classified into different levels such as very volatile like methane, volatile (reactive VOCs like isoprenes and terpenes), and semi-volatile (non-reactive VOCs). The classification of VOCs is based on their occurence, reactivity, physical properties and boiling points. The volatiles can be released by natural processes or by anthropogenic origin. In nature, VOCs are produced by chemical reactions in plants (Feussner 
et al., 1997), animals (Paczkowski 2013) or fungi (Thakeow et al., 2008), as well as by the burning of plant products during forest fires (Schütz et al., 1999a). Anthropogenically emitted VOCs can be produced by industrial processes (Graedel 1994) or by transport (Na 2006). VOCs are currently investigated in different research fields. These include atmospheric chemistry, as high concentrations of VOCs are harmful to humans (Granström 2002; Parkinson et al., 2008; Maleknia et al., 2009).

\subsection{Roles of VOCs for insects}

Insects use their antennal olfactory sensilla to recognize different VOCs. These play an important role for basic ecological purposes such as mating (Pelosi \& Maida 1995), oviposition (Verheggen et al., 2008), finding food resources (Beck et al., 2012), and interspecific communication (Reyes-Vidal 2009). The specific roles of these VOCs are difficult to define due to their complex functions in the ecosystem (Nordlund et al., 1981). Chemicals used to exchange information and to mediate the interspecific or intraspecific interaction between organisms are so called semiochemicals. Intraspecific interaction refers to communications between different individuals of the same species within communities. Interspecific interactions refer to the communications between different species, mediated by allelochemicals.

Pheromones are defined as semiochemicals for intraspecific communication (Schaefer 2012). Pheromones play a critical role in the sexual communication of insects, for example in the lepidopteran species Bombyx mori (Maida et al., 1993; Sakurai et al., 2004) or Lymantria dispar (Plettner et al., 2000). Moreover, pheromones are used by many ants to direct recruit foragers to food sources (Gruter et al., 2012), alarming of a group (Vandermoten et al., 2012) and the selection of oviposition sites (Nufio \& Papaj 2001). Apneumones are emitted by organic matter and can have both advantages and disadvantages for one insect species at the same time. As an advantage, apneumones attract one insect species to a food source. However, they also attract the predators of this species (Aak et al., 2010).

Allelochemicals arbitrate a beneficial relationship between sender and receiver (Ruther 2002). While kairomones provide a benefit for the receiver (e.g. by informing a predator about the location of its prey), allomones benefit the sender (Burger 1988; Ruther 2002; Schaefer 2012), for example by defense against predators. In contrast to kairomones and allomones, synomones mediate a benefit for both sender and receiver (Shepherd 2007). Thus, competition between two species is avoided. 


\subsection{Formation of VOCs}

Volatile organic compounds are emitted by many different sources. Plants release VOCs as byproducts of their metabolic activities (Peñuelas \& Llusià 2004). Woody material (e.g. tree trunks and deadwood) are another major source of plant-related VOC, as well as wood products. Fungi and fungus-infested wood also release VOCs (Holighaus 2012). Volatiles are further produced by the thermal oxidation of wood.

Wood consists of two main components: carbohydrate (hemicelluloses, cellulose) and lignin, as well as extractives (like waxes, fatty acids, resin acids, phenolic compounds, and terpenes of a tree). In general, softwood species have the same cellulose (40-45\%) and lignin (26-34\%) content in comparison to hardwood species (cellulose 38-49\%, lignin 23-30\%). However, the hemi-celluloses in general of softwood species is higher than their content in hardwood hemicellulose. According to Granström (2002), VOC emissions and degradation products of wood constituents differ between and among tree species and even on the same tree (see Kollmann 1982; Hyttinen et al., 2010). Especially, these differences are highly recognized between softwood and hardwood due their differences in cell types (Sjostrom 1993). The release of VOCs from wood varies with air temperature and thermal degradation of wood (Manninen et al., 2002; Hyttinen et al., 2010).

Released at ambient temperature, terpenes are the major important group of extractives (Englund \& Nussbaum 2000; Banerjee 2001; Granström 2002; Manninen et al., 2002). The chemical reaction of terpenes can lead to the formation of new compounds (Neuenschwander et al., 2010).

Fatty acids are among the major group of wood extractives. They are distributed in vesicles and the phospholipid membranes of the parenchyma cells of wood (Sjostrom 1993). These membranes contain large amounts of linoleic and arachidonic acid (Frankel 1983). Fatty acids are degraded by the processes of thermal degradation (Paczkowski et al., 2011), autolysis or reactive oxygen species (Choe \& Min 2005), and by microorganisms (Paczkowski et al., 2011). During these processes, some VOCs can be formed. For example, the aldehydes hexanal, heptanal, nonanal and decanal are formed during autolysis or oxidation by reactive oxygen species (Risholm-Sudman et al., 1998; Svedberg et al., 2004; Arshadi 2005; Roffael 2006). However, some early studies found that aldehydes can also be formed by thermal degradation processes (Arshadi 2005) and by the metabolism of fungi (Combet et al., 2006). The oxidation process of unsaturated fatty acids leads to the formation of hexanal (Risholm-Sundman et al., 1998). Nonetheless, little is still known about the formation of volatile products during the oxidation of lipid (Kionka \& Kunau 1985; Heath et al., 2002; Combet et al., 2006). 


\subsection{Carbohydrate polymers}

The major constituents of carbohydrates are composed of hemicellulose and cellulose polymers, with a small amount of sugar polymers like pectin and starch (Stamm 1964). Hemicelluloses are heteropolymers. Their structure includes different hexose and pentose sugars.

The polymerization of the most abundant pentose sugars D-xylose and L-arabinose with other sugars (like glucose, mannuronic acid and arabinose, see Sjostrom 1993) results in the formation of arabinoxylan, glucuronoxylan, glucomannan, xylan and xyloglucan (Sjostrom 1993). Hemicelluloses are very sensitive to heat, especially their sugar component xylan (pentosan) (Kotilainen 2000). Acetic acid is formed during the thermal deacetylation of hemicelluloses (Risholm-Sundman et al., 1998; Kotilainen 2000). The thermal degradation of pentoses and hexoses leads to the formation of hydroxyacetone and furanes such as 2pentylfurane, furfural and methylated furfural (Fengel \& Wegener 1984; Risholm-Sudman et al., 1998; Tjeerdsma et al., 1998; Oasmaa et al., 2003; Cheda et al., 2006; Roffael 2006).

\subsection{Cellulose}

Cellulose is a glucan polymer of D-glucopyranose units linked together by $1,4-\beta$-glycosidic bonds. The number of glucose units in the cellulose molecule is referred to as degree of polymerization (DP). Wood cellulose has an average DP of at least 9,000-10,000 molecules and possibly as high as 15,000 molecules (Goring \& Timell 1962). The subunits of cellulose polymers are connected with each other and molecule plane is turned by $180^{\circ} \mathrm{C}$. All these subunits together form linear cellulose chains (Fig. 3.1).

Cellulose is known to be more thermally stable than hemicelluloses (Kotilainen 2000). The cleavage of the 1,4- $\beta$-glycosidic bonds during the thermal degradation process leads to the formation of hydroxyacetone (Piskorz et al., 1986; Zhang et al., 2008), 5-methylfurfural (Oasmaa et al., 2003) and 3-methyl-2H-furo[2,3-c]pyran-2-one, also known as karrikinolide (Flematti et al., 2011) (Fig. 3.2). During the thermal degradation process of cellulose, levoglucosan is released at temperatures above $200^{\circ} \mathrm{C}$, followed by the release of furan derivatives (Risholm-Sundman et al., 1998; Kotilainen 2000). Figure 3.3 shows that thermal degradation of cellulose leads to the formation of furan derivatives, mainly 2furancarboxaldehyde (furfural).

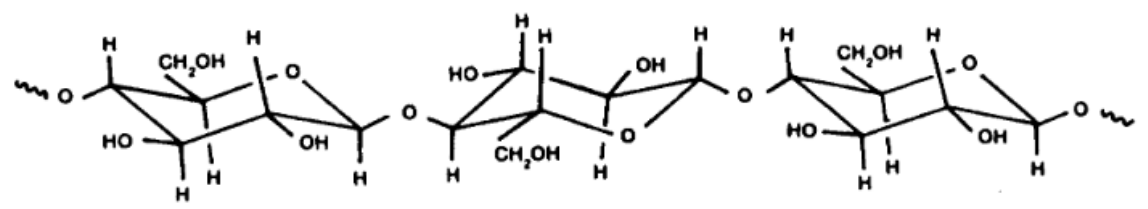


Figure 3.1: The partial molecular structure of cellulose $[(\mathrm{C} 6 \mathrm{H} 10 \mathrm{O} 5)]$ in the 1,4- $\beta$-D glucopyranose form.

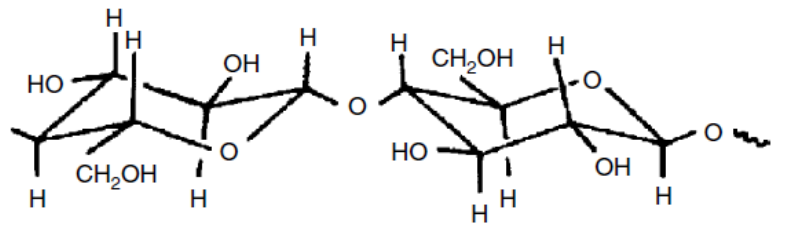

Figure 3.2: Chemical structure of cellobiose.<smiles>O=CC1O[C@H](O)C(O)[C@@H](O)C1O</smiles><smiles>OC1=CC([18OH])C([18OH])O[C@H](O)C1O</smiles><smiles>CC(C)CCO</smiles><smiles>[R9]C(C=C(C)O)C(O)CO</smiles>

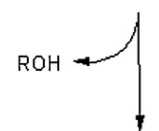<smiles>O=Cc1ccco1</smiles><smiles>CCCCCCCCCC</smiles><smiles>O=Cc1ccc(CO)o1</smiles><smiles>C[C@H](O)CC(=O)/C=C/C(O)CO</smiles>

Figure 3.3: Proposed route to 5-methylfurfural and furfural from cellulose (Flematti et al., 2011).

\subsection{Lignin}

Lignin is a biopolymer consisting of different monomeric constituents and differs between hardwood and softwood. The main precursor of softwood lignin is synapylalcohol (Sjostrom 1993). Hardwood lignin mainly consists of the two biochemically polymerized phenylpropanoids coniferyl alcohol and sinapyl alcohol (Sjostrom 1993), which are mainly connected by the $\beta-\mathrm{O}-4$ bond. Other bonds like biphenyl- or $\beta$ - $\beta$-bonds (Higuchi 1990) are products of the biochemical radicalization of sinapyl or coniferyl alcohol. The lignin precursor (dimeric chinomethid) is therefore the product of this radicalization process. In plant growth, sinapyl or coniferyl alcohol is transformed into hardwood lignin molecules (Higuchi 1990; Sjostrom 1993) (Fig. 4). 


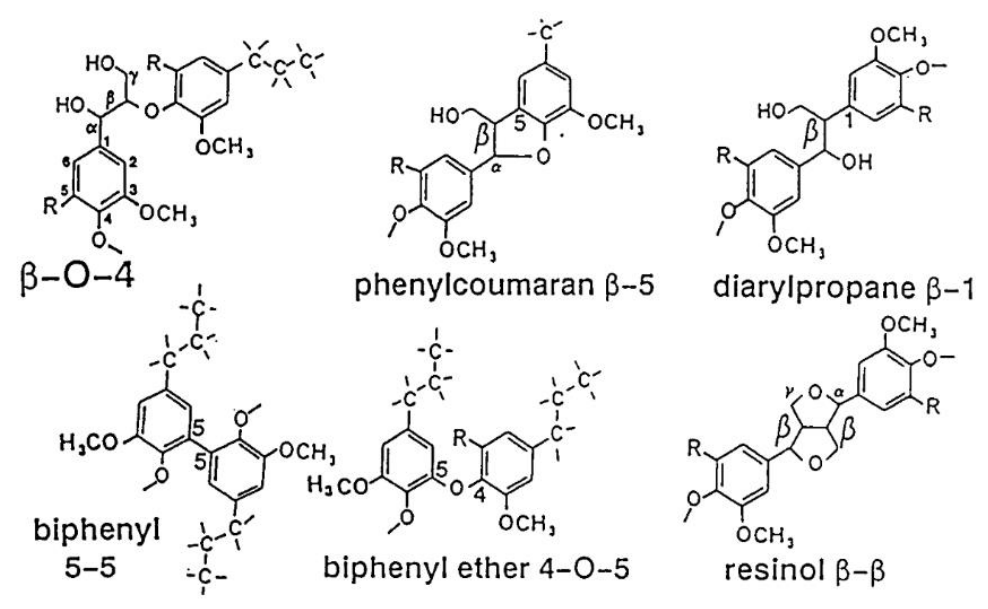

Figure 4: Principal bonding patterns between guaiacyl $(\mathrm{R}=\mathrm{H})$ and syringyl $\left(\mathrm{R}=\mathrm{OCH}_{3}\right)$ units in hardwood lignins (Lapierre et al., 1994).

Under the physical influence of heat, the links between the polymerized coniferyl and sinapyl are broken down to their smaller components. The thermal oxidization of these components leads to the formation of guaiacol derivatives such as 4-methylguaiacol, 4-ethylguaiacol, eugenol and other compounds (Fig. 4) (Karagoz et al., 2005; Branca et al., 2006; Ingram et al., 2008 and Azeez et al., 2010). These compounds can also be formed during the oxidization process of lignin by white rot fungi (Oudia et al., 2008).

\subsection{Objective of this thesis}

At the beginning of this work, nothing was known about the presence of pyrophilous insects in Vietnam, although several pyrophilous insect species are known to occur in Europe, America, and Australia. Several studies have investigated the attraction of pyrophilous insects toward VOCs released upon heating up of wood (Schütz et al., 1999a; Paczkowski et al., 2013). Some other studies focus on the presence of IR receptors in pyrophilous insects (Evans 1964; Schmitz et al., 1997, 2000, 2002, 2008 and 2010). Forest fires are taking place very frequently in Vietnam (Le et al., 2014), suggesting the potential existence of fire-loving species in fire-prone regions (Hoang \& Schütz 2015; Geiser 2016). Therefore, this study aimed to examine recently burnt habitats in Vietnam for the presence of pyrophilous insects and to identify cues suitable for them to find such habitats. This includes morphological and chemo-ecological studies unravelling the significance of IR receptors, IR radiation, volatile signals, and the respective behavior induced by such cues.

The experiments of the thesis are presented in four chapters (chapter 2 to chapter 5) representing manuscripts for publication on their own. Chapter 6 discusses the general outcome of this thesis. The presentation of experiments was subdivided according to 1) the presence of 
pyrophilous insects in the Vietnam Central Highlands (chapter 2), 2) the attraction of insects in recently burnt habitat to common fire-specific VOCs released by different Vietnamese woody plant species upon heating (chapter 3), 3) the attraction of pyrophilous insects to firespecific VOCs and IR radiation and combination of both stimuli (chapter 4), and 4) the behavior and sensory adaptation of the pyrophilous flat bug Aradus candidatus (chapter 5).

The respective chapters aim to address the following questions:

1) Are there pyrophilous insects in Vietnam?

(Chapters 2 and 5)

2) How does the diversity of VOCs correlate with the insect diversity in recently burnt habitats?

(Chapter 3)

3) Are burnt wood VOCs a cue for pyrophilous insects to find burnt habitats?

(Chapters 3 and 4 \& 5)

4) Is infrared radiation a cue for pyrophilous insects to find burnt habitats?

(Chapter 4 \& 5)

5) How does insect attraction to recently burnt habitats differ between VOCs, IR stimuli or both stimuli?

(Chapters 4 and 5)

6) Is multimodal sensing important for the behavior of pyrophilous insects?

(Chapter 5) 


\subsection{References}

Aak, A., Knudsen, G. K. and Soleng, A. (2010). Wind tunnel behavioral response and field trapping of the blowfly Calliphora vicina. Medical and Veterinary Entomology, 24(3): 250257.

Apel, K. H. (1988). Befallsverteilung von Melunophila acuminata DEG., Phaenops cyanea F. und $\mathrm{Ph}$. formnneki JACOB (Col., Buprestidae) auf Waldbrandflachen. Beiträge für Forstwirtschaft, 22:45-48.

Apel, K. H. (1989). Zur Verbreitung von Melunophilu acuminata DEG. (Col., Buprestidae). Entomol. Nach. Ber. 33, 278-280.

Arshadi, M. (2005). Emission of volatile organic compounds from softwood pellets during storage. Forest Products Journal, 55(12): 132-135.

Azeez, A. M., Meier, D., Odermatt, J. and Willner, T. (2010). Fast pyrolysis of African and European lignocellulosic biomasses using Py-GC/MS and fluidized bed reactor. Energy \& Fuels, 24(3): 2078-2085.

Banerjee, S. (2001). Mechanisms of terpene release during sawdust and flake drying. Holzforschung, 55(4): 413-416.

Beck, J. J., Higbee, B. S., Light, D. M., Gee, W. S., Merrill, G. B. and Hayashi, J. M. (2012). Hull split and damaged almond volatiles attract male and female navel orange worm moths. Journal of Agricultural and Food Chemistry, 60(33): 8090-8096.

Branca, C., Di Blasi, C. and Elefante, R. (2006). Devolatilization of conventional pyrolysis oils generated from biomass and cellulose. Energy \& Fuels, 20(5): 2253-2261.

Briscoe, A. D. and Chittka, L. (2001). The evolution of colors vision in insects. Annual Review of Entomology, 46: 471-510.

Bullock, H. T. and Cowles, B. R. (1952). Physiology of an Infrared Receptor: The Facial Pit of Pit Vipers. Science, 115(2994): 541-543.

Bullock, H. T. and Fox, W. (1957). The Anatomy of the Infra-red Sense Organ in the Facial Pit of Pit Vipers. Journal of Cell Science, 3(98): 219-234.

Burger, B. V., Munro, Z. M. and Visser, J. H. (1988). Determination of plant volatiles 1: Analysis of the insect-attracting allomone of the parasitic plant Hydnora africana using GrobHabich activated charcoal traps. Journal of High Resolution Chromatography \& Chromatography Communications, 11(6): 496-499.

Champion, G. C. (1909). A buprestid and other Coleoptera on pine injured by "heath fires" in N.W. Surrey. Entomologist's Monthly Magazine, 45, 247-250.

Champion, G.C., (1922). The geographical distribution and synonymy of the dasytid-beetle Acanthocnemus nigricans HOPE (Zciliatus PERRIS). Entomologist's Monthly Magazine (Series 3.8), 58: 77-79.

Cheda, J. N., Roman-Leshkov, Y. and Dumesic, J.A. (2006). Production of 5hydroxymethylfurfural and furfural by dehydration of biomass-derived mono- and polysaccharides. Green Chemistry, 9(4): 342-350. 
Choe, E. and Min, D. B. (2005). Chemistry and reactions of reactive oxygen species in foods chromatography. Journal of Chromatography A, 1216(10): 1607-1623.

Combet, E., Henderson, J., Eastwood, C. D. and Burton, K. S. (2006). Eight-carbon volatiles in mushrooms and fungi, properties, analysis, and biosynthesis. Mycoscience, 47(6): 317-326.

Danks, H. V. and Foottit, R. G. (1989). Insects of the boreal zone of Canada. The Canadian Entomologist, 121(8): 625-690.

Englund, F. and Nussbaum, R. M. (2000). Monoterpenes in Scots pine and Norway spruce and their emission during kiln drying. Holzforschung, 54(5): 449-456.

Esseen, P.-A., Ehnström, B., Ericson, L. and Sjöberg, K. (1992). Boreal forests - the focal habitats of Fennoscandia. Pp. 252-325 in: Hansson, L. (ed.): Ecological Principles of Nature Conservation. Elsevier, London, 436 pp.

Evans, W. G. (1962). Notes on the biology and dispersal of Melanophilu (Coleoptera: Buprestidae). Pan-Pacific Entomology, 38: 59-62.

Evans, W. G. (1964). Infrared receptors in Melanophila acuminata De Geer. Nature (Lond.) 202: 211.

Evans, W. G. (1966). Perception of infrared radiation from forest by Melanophila acuminata (Buprestidae, Coleoptera). Ecology 47: 1061-1065.

Fengel, D. and Wegener, G. (1984). Wood, chemistry, ultrastructure, reactions. De Gruyter Inc., Boston, USA.

Feussner, I., Kühn, H. and Wasternack, C. (1997). Do specific linoleate 13-lipoxygenases initiate $\beta$-oxidation? FEBS Letters, 406: 1-5.

Flematti, G. R., Scaffidi, A., Dixon, K. W., Smith, S. M. and Ghisalberti, E. L. (2011). Production of the seed germination stimulant karrikinolide from combustion of simple carbohydrates. Journal of Agricultural and Food Chemistry, 59(4): 1195-1198.

Forbes, S. L., Stuart, B. H. and Dent, B. B. (2002). The identification of adipocere in grave soils. Forensic Science International, 127(3): 225-230.

Forbes, S. L., Dent, B. B. and Stuart, B. H. (2005a). The effect of soil type on adipocere formation. Forensic Science International. 154(1): 35-43.

Forbes, S. L., Stuart, B. H. and Dent, B. B. (2005b). The effect of the burial environment on adipocere formation. Forensic Science International, 154(1): 24-34.

Forbes, S. L., Stuart, B. H. and Dent, B. B. (2005c). The effect of the method of burial on adipocere formation. Forensic Science International, 154(1): 44-52.

Frankel, E. N. (1983). Volatile lipid oxidation-products. Progress in Lipid Research, 22: 1-33. 
Gamow, R.I. \& Harris, F.J. (1973). The Infrared Receptors of Snakes. Scientific American, 228(5): 94-101.

Geiser, M. (2016). An update on the distribution of the pyrophilous beetle Acanthocnemus nigricans (Hope, 1845) (Coleoptera: Cleroidea: Acanthocnemidae), including new records from Laos. Entomologica Basiliensia et Collectionis Frey, 35: 429-432.

Geiszler, D. R., Gara, R. I., Driver, C. H., Gallucci, V. F., and Martin, R. E. (1980). Fire, fungi, and beetle influences on a lodgepole pine ecosystem of south-central Oregon. Oecologia, 46(2): 239-243.

Goring, D. A. I. and Timell, T. E. (1962). Molecular weight of native celluloses. Tappi 45: 454-460.

Graedel, T. (1994). Industrial ecology: definition and implementation. Pp. 23-43 in: Socolow, R., Andrews, C., Berkhout, F. and Thomas, V. (eds): Industrial Ecology and Global Change, Cambridge University Press, Cambridge, United Kingdom, 500 pp.

Granström, K. (2002). Emissions of monoterpenes and VOCs during drying of sawdust in a spouted bed. Forest Products Journal, 53(10): 48-55.

Grimaldi, D. and Engel, M. S. (2005). Evolution of the insects. Cambridge University Press, Cambridge, United Kingdom.

Groot, M., Cokl, A. and Virant-Doberlet M. (2010). Effects of heterospecific and conspecific vibrational signal overlap and signal-to-noise ratio on male responsiveness in Nezara viridula (L.). Journal of Experimental Biology, 213: 3213-3222.

Gruter, C., Schurch, R., Czaczkes, T. J., Taylor, K., Durance, T., Jones, S. M., et al. (2012). Negative feedback enables fast and flexible collective decision-making in ants. PLoS ONE 7(9): e44501. doi:10.1371/journal.pone.0044501.

Hansson, B. S. (1999). Insect Olfaction. Springer, New York, 458 pp.

Heath, R. J., Jackowski, S. and Rock, C. O. (2002). Fatty acid and phospholipid metabolism in prokaryotes. Pp. 59-96 in: Vance, D. E. and Vance, J. E. (eds.): Biochemistry of lipids, lipoproteins and membranes. Elsevier, San Francisco, USA, 612 pp.

Heisswolf, A., Gabler, D., Obermaier, E. and Muller, C. (2007). Olfactory versus contact cues in host plant recognition of a monophagous chrysomelid beetle. Journal of Insect Behavior, 20: 247-266.

Higuchi, T. (1990). Lignin biochemistry, Biosynthesis and biodegradation. Wood Science and Technology, 24(1): 23-63.

Hjältén, J., Atlegrim, O., Sandström, F., Pettersson, R. and Rexstad, E. A. (2006). Occurrence of flat bugs (Heteroptera: Aradidae) in burned and unburned forests. Entomologica Fennica, 17: 130-135.

Hoang, M. D. (2007). Ecology and Conservation Status of the Black-shanked Douc (Pygathrix nigripes) in Nui Chua and Phuoc Binh National Parks, Ninh Thuan Province, Vietnam. Ph.D. 
Thesis, School of Natural \& Rural Systems Management, The University of Queensland, Australia.

Hoang, T. P. and Schütz, S. (2015). Pyrophilous insects in Vietnam central highlands. Mitteilungen Deutsche Gesellschaft für allgemeine und angewandte Entomologie, 20: 133138.

Holighaus, G. (2012). Odour signals relevant to beetles in deadwood habitats. PhD Thesis. Faculty of Forest Sciences and Forest Ecology. University of Göttingen, Germany.

Hyttinen, M., Masalin-Weijo, M., Kalliokoski, P., Pasanen, P. (2010). Comparison of VOC emissions between air-dried and heat-treated Norway spruce (Picea abies), Scots pine (Pinus sylvesteris) and European aspen (Populus tremula) wood. Atmospheric Environment, 44(38): 5028-5033.

Ingram, L., Mohan, D., Bricka, M., Steele, P., Strobel, D., Crocker, D., et al. (2008). Pyrolysis of wood and bark in an auger reactor. Physical properties and chemical analysis of the produced bio-oils. Energy \& Fuels, 22(1): 614-625.

Karagoz, S., Bhaskar, T., Muto, A. and Sakata, Y. (2005). Comparative studies of oil compositions produced from sawdust, rice husk, lignin and cellulose by hydrothermal treatment. Fuel, 84(7-8): 875-884.

Kionka, C. and Kunau, W. H. (1985). Inducible $\beta$-oxidation pathway in Neurospora crassa. Journal of Bacteriology, 161(1), 153-157.

Klocke, D., Schmitz, A., Soltner, H., Bousack, H. and Schmitz H. (2011). Infrared receptors in pyrophilous ("fire loving") insects as model for new un-cooled infrared sensors. Beilstein Journal of Nanotechnology, 2: 186-197.

Kollmann, F. (1982). Technologie des Holzes und der Holzwerkstoffe, Anatomie und Pathologie, Chemie, Physik, Elastizität und Festigkeit. Springer, Berlin, Germany, 1051 pp.

Kotilainen, R. A., Toivanen, T. J. and Alén, R. J. (2000). FTIR Monitoring of Chemical Changes in Softwood During Heating. Journal of Wood Chemistry and Technology, 20 (3): 307-320.

Kreiss, E., Schmitz, H. and Gebhardt, M. (2007). Electrophysiological characterization of the infrared organ of the Australian "little ash beetle" Acanthocnemus nigricans (Coleoptera, Acanthocnemidae). Journal of Comparative Physiology, 193(7): 729-739.

Lapierre, C., Monties, B., Meier, D. and Faix, O. (1994). Structural investigation of Kraft lignins transforrned via oxo-ammoniation to potential nitrogenous fertilizers. Holiforschung, 48 (S1): 63-68.

Lazzari, C. R. and Nunez, J. A. (1989). The response to radiant heat and the estimation of the temperature of distant sources in Triatoma infestans. Journal of Insect Physiology, 35(6): 525-529.

Le, T. H., Thanh Nguyen, T. N., Lasko, K., Ilavajhala, S., Vadrevu, K. P. and Justice, C. (2014). Vegetation fires and air pollution in Vietnam. Environmental Pollution, 195: 267-275. 
Levin, S. A. and Paine, R. T., (1974). Disturbance, patch formation, and community structure. Proceedings of the National Academy of Sciences of the United States of America, 71: 2744-2747.

Linksvayer, T. A., Fewell, J. H., Gadau, J. and Laubichler, M. D. (2012). Developmental evolution in social insects, regulatory networks from genes to society. Journal of Experimental Zoology, B: Molecular and Developmental Evolution, 318(3): 159-169.

Linsley, E. G. (1943). Attraction of Melanophila beetles by fire and smoke. Journal of Economic Entomology. 36, 341-342.

Maida, R., Steinbrecht, A., Ziegelberger, G. and Pelosi, P. (1993). The pheromone binding protein of Bombyx mori, purification, characterization and immunocytochemical localization. Insect Biochemistry and Molecular Biology, 23(2): 243-253.

Maleknia, S. D., Bell, T. L. and Adams, M. A. (2009). Eucalypt smoke and wildfires, temperature dependent emissions of biogenic volatile organic compounds. International Journal of Mass Spectrometry, 279(2-3): 126-133.

Manninen, A. M., Pasanen, P. and Holopainen, J. K. (2002). Comparing the VOC emissions between air-dried and heat-treated Scots pine wood. Atmospheric Environment, 36(11): 17631768 .

McNamara, S., Tinh, D. V., Erskine, P. D., Lamb, D., Yates, D., \& Brown, S. (2006). Rehabilitating degraded forest land in central Vietnam with mixed native species plantings. Forest Ecology and Management, 233(2-3): 358-365.

Muona, J. and Rutanen, I. (1994). The short-term impact of fire on the beetle fauna in boreal coniferous forest. Annales Zoologici Fennici, 31(1): 109-121.

Na, K. (2006). Determination of VOC source signature of vehicle exhaust in a traffic tunnel. Journal of Environmental Management, 81(4): 392-398.

Nation, J. L. (2001). Insect physiology and biochemistry. CRC Press, New York, USA, 560 pp.

Neuenschwander, U., Guignard, F. and Hermans, I. (2010). Mechanism of the aerobic oxidation of alpha-pinene. ChemSusChem, 3(1): 75-84.

New, T. R. (2014). Insects, Fire and Conservation. Springer, Basel, Switzerland, 208 pp.

Nicholson, G. W. (1919). Melanophila acuminata De Geer at a fire in June. Entomologist's Monthly Magazine, 55: 156-157.

Nordlund, D. A., Jones, R. L. and Lewis, W. J. (1981). Semiochemicals. Their role in pest control. Wiley VCH, New York, USA, 306 pp.

Nufio, C. R. and Papaj, D. R. (2001). Host marking behavior in phytophagous insects and parasitoids. Entomologia Experimentalis et Applicata, 99: 273-293.

Oasmaa, A., Kuoppala, E. and Solantausta, Y. (2003). Fast pyrolysis of forestry residue. 2. Physicochemical composition of product liquid. Energy \& Fuels, 17(2): 433-443. 
Oudia, A., Queiroz, J. and Simoes, R. (2008). Potential and limitation of Trametes versicolor laccase on biodegradation of Eucalyptus globulus and Pinus pinaster kraft pulp. Enzyme and Microbial Technology, 43(2): 144-148.

Paczkowski, S., Sauerwald, T., Weiß, A., Bauer, M., Kohl, C.-D. and Schütz, S. (2011). Biomimetic gas sensors for large-scale drying of wood particles. Martin-Palma, R. J. and Lakhtakia, A. 7975, 797505-797505-8. Conference Proceedings of the SPIE: Bioinspiration, Biomimetics, and Bioreplication, San Diego, USA.

Paczkowski, S. (2013). Insect olfaction as an information filter for chemo-analytical applications. PhD Thesis. Faculty of Forest Sciences and Forest Ecology. University of Göttingen, Germany.

Paczkowski, S., Paczkowska, M., Dippel, S., Schulze, N., Schütz, S., Sauerwald, T., et al. (2013). The olfaction of a fire beetle leads to new concepts for early fire warning systems. Sensors and Actuators, B: Chemical, 183: 273-282.

Parkinson, P. R., Churchill, T. J. and Rolls, W. (2008). Assessment of matrix effects on methyl benzoate, a potential biomarker for detection of outgassed semi-volatiles from mold in indoor building materials. Bulletin of Environmental Contamination and Toxicology. 81(5): 494-497.

Pelosi, P. and Maida, R. (1995). Odorant-binding proteins in insects. Comparative Biochemistry and Physiology B-Biochemistry \& Molecular Biology, 111(3): 503-514.

Peñuelas, J. and Llusià. J. (2004). Plant VOC emissions: making use of the unavoidable. Trends in Ecology \& Evolution, 19(8):402-404.

Picket, S. T. A. and White, P. S. (1985). The ecology of natural disturbance and patch dynamics. Academic Press, London, United Kingdom, 472 pp.

Piskorz, J., Radlein, D. and Scott, D. S. (1986). On the mechanism of the rapid pyrolysis of cellulose. Journal of Analytical and Applied Pyrolysis, 9(2): 121-137.

Plettner, E., Lazar, J., Prestwich, E. G. and Prestwich, G. D. (2000). Discrimination of pheromone enantiomers by two pheromone binding proteins from the gypsy moth Lymantria dispar. Biochemistry, 39(30): 8953-8962.

Poulton, E. B., (1915). The habits of the Australian buprestid "fire beetle", Merimna atrata, Lap. et Gory. Transactions of the Entomological Society of London, Part 1: iii-iv.

Prodon, R. (1987). Fire, bird conservation and land management in the North-Mediterranean area. Ecol Mediter 13:127-133.

Reyes-Vidal, Y. and de la Torre, M. (2009). Emission, perception, and behavioral responses of entomopathogenic nematodes to semiochemicals. Nematropica, 39(2): 213-223.

Risholm-Sudman, M., Lundgren, M., Vestin, E. and Herder, P. (1998). Emissions of acetic acid and other volatile organic compounds from different species of solid wood. Holz als Rohund Werkstoff, 56(2): 125-129. 
Roffael, E. (2006). Volatile organic compounds and formaldehyde in nature, wood and woodbased panels. Holz als Roh- und Werkstoff, 64(2), 144-149.

Ruther, J., Meiners, T. and Steidle, J. L. M. (2002). Rich in phenomena-lacking in terms. A classification of kairomones. Chemoecology, 12: 161-167.

Sakurai, T., Nakagawa, T., Mitsuno, H., Mori, H., Endo, Y., Tanoue, S., et al. (2004). Identification and functional characterization of a sex pheromone receptor in the silkmoth Bombyx mori. Proceedings of the National Academy of Sciences of the United States of America, 101(47): 16653-16658.

Schaefer, M. (2012). Wörterbuch der Ökologie. Spektrum Verlag, Heidelberg, Germany, 392 pp.

Schmitz, H. and Bleckmann, H. (1997). Fine structure and physiology of the infrared receptor of beetles of the genus Melanophila (Coleoptera: Buprestidae). International Journal of Insect Morphology and Embryology, 26(3-4): 205-215.

Schmitz, H. and Bleckmann, H. (1998). The photomechanic infrared receptor for the detection of forest fires in the beetle Melanophila acuminata (Coleoptera: Buprestidae). Journal of Comparative Physiology, 182(5): 647-657.

Schmitz, H., Schmitz, A. and Horst, B. (2000). New type of infrared organ in the Australian "fire-beetle" Merimna atrata (Coleoptera: Buprestidae). Naturwissenschaften, 87: 542-545.

Schmitz, H., Schmitz, A., Trenner, S. and Bleckmann, H. (2002). A new type of insect infrared organ of low thermal mass. Naturwissenschaften, 89(5): 226-229.

Schmitz, A., Sehrbrock, A. and Schmitz, H. (2007). The analysis of the mechanosensory origin of the infrared sensilla in Melanophila acuminata (Coeloptera; Buprestidae) adduces new insight into the transduction mechanism. Arthropod Structure and Development, 36(3), 291-303.

Schmitz, A., Gebhardt, M. and Schmitz, H. (2008). Microfluidic photomechanic infrared receptors in a pyrophilous flat bug. Naturwissenschaften, 95(5): 455-460.

Schmitz, A., Schätzel, H. and Schmitz, M. (2010). Distribution and functional morphology of photomechanic infrared sensilla in flat bugs of the genus Aradus (Heteroptera, Aradidae). Arthropod structure \& development 39(1): 17-25.

Schöning, M. J., Schütz, S., Schroth, P., Weißbecker, B., Steffen, A., Kordos, P., et al. (1998). A BioFET on the basis of intact insect antennae. Sensors and Actuators B: Chemical, 47(1-3): 235-238.

Schütz, S., Weißbecker, B., Hummel, H. E., Schöning, M. J., Riemer, A., Kordos, P., et al. (1997a). Field effect transistor-insect antenna junction. Naturwissenschaften, 84: 86-88.

Schütz, S., Weißbecker, B., Klein, A. and Hummel, H. E. (1997b). Host plant selection of the Colorado potato beetle as influenced by damage induced volatiles of the potato plant. Naturwissenschaften, 84: 212-217. 
Schütz, S., Weißbecker, B., Hummel, H. E., Apel, K.-H., Schmitz, H. and Bleckmann, H. (1999a). Insect antenna as a smoke detector. Nature, 398: 298-299.

Schütz, S., Weißbecker, B., Koch, U. T. and Hummel, H. E. (1999b). Detection of volatiles released by diseased potato tubers using a biosensor on the basis of intact insect antennae. Biosensors and Bioelectronics, 14(2): 221-228.

Schütz, S. and Weißbecker, B. (2003). Mechanismen duftvermittelter Pflanze-InsektInteraktionen. Vom Pflanzenstress zum Pflanzenfraß. Nova Acta Leopoldina, 87: 215-235.

Shepherd, W. P., Huber, D. P. W., Seybold, S. J. and Fettig, C. J. (2007). Antennal responses of the western pine beetle, Dendroctonus brevicomis (Coleoptera: Curculionidae), to stem volatiles of its primary host, Pinus ponderosa, and nine sympatric nonhost angiosperms and conifers. Chemoecology, 17(4): 209-221.

Singh, R.N. (1998). Neurobiology of the gustatory system of Drosophila and some terrestrial insects. Microscopy Research and Technique, 39(6): 547-563.

Sjostrom, E. (1993). Wood Chemistry, Second Edition, Elsevier, San Francisco, USA, 293 pp.

Stamm, A. J. (1964). Wood and cellulose science. Ronald Press Co. New York, USA.

Svedberg, U. R. A., Högberg, H. E., Högberg, J. and Galle, B. (2004). Emission of hexanal and carbon monoxide from storage of wood pellets, a potential occupational and domestic health hazard. Annals of Occupational Hygiene, 48(4): 339-349.

Swengel, B. A. (2001). A literature review of insect responses to fire, compared to other conservation managements of open habitat. Biodiversity \& Conservation, 10(7): 1141-1169.

Swezy, D. M. and Agee, J. K. (1991). Prescribed-fire effects on fine-root and tree mortality in old-growth ponderosa pine. Canadian Journal of Forest Research, 21(5): 626-634.

Thakeow, P., Angeli, S., Weißbecker, B. and Schütz, S. (2008). Antennal and behavioral responses of Cis boleti to fungal odor of Trametes gibbosa. Chemical Senses, 33(4): 379-387.

The Forest Protection Department (FPD) of Vietnam. http://www.flegt.org/web/vietnamforest-protection-department

Tjeerdsma, B. F., Boonstra, M., Pizzi, A., Tekely, P. and Militz, H. (1998). Characterisation of thermally modified wood, molecular reasons for wood performance improvement. Holz als Roh- und Werkstoff, 56: 149-153.

Vandermoten, S., Mescher, M. C., Francis, F., Haubruge, E. and Verheggen, F. J. (2012). Aphid alarm pheromone: An overview of current knowledge on biosynthesis and functions. Insect Biochemistry and Molecular Biology, 42(3): 155-163.

Verheggen, F. J., Arnaud, L., Bartram, S., Gohy, M. and Haubruge, E. (2008). Aphid and plant volatiles induce oviposition in an aphidophagous hoverfly. Journal of Chemical Ecology. 34(3): 301-307. 
Vogt, R. G. and Riddiford, L. M. (1981). Pheromone binding and inactivation by moth antennae. Nature, 293: 161-163.

Vondran, T,. Apel, K.H. and Schmitz, H. (1995). The infrared receptor of Melanophila acuminata De Geer (Coleoptera: Buprestidae): ultrastructural study of a unique insect thermoreceptor and its possible descent from a hair mechanoreceptor. Tissue and Cell, 27(6): 645-658.

Weißbecker, B., Holighaus, G. and Schütz, S. (2004). Gas chromatography with mass spectrometric and electroantennographic detection, analysis of wood odorants by direct coupling of insect olfaction and mass spectrometry. Journal of Chromatography A, 1056(1-2): 209-216.

Wikars, L. O. (1997). Effects of forest fire and the ecology of fire-adapted insects. Comprehensive Summaries of Uppsala Dissertations from the Faculty of Science and Technology 272. Acta Universitatis Upsaliensis, Uppsala, Sweden, 272 pp.

Wikars, L. O. (2002). Dependence on fire in wood-living insects: An experiment with burned and unburned spruce and birch logs. Journal of Insect Conservation 6: 1-12.

Wright, H. A. and Bailey, A. W. (1982). Fire ecology, United States and southern Canada. John Wiley and Sons, New York, USA, $501 \mathrm{pp}$.

Zhang, B., Huang, H. J. and Ramaswamy, S. (2008). Reaction kinetics of the hydrothermal treatment of lignin. Applied Biochemistry and Biotechnology, 147(1-3): 119-131. 


\section{Chapter 2}

\section{Pyrophilous insects in Vietnam Central Highlands}

Published as:

Hoang, T. P*., and Schütz, S. (2015). Pyrophilous Insects in Vietnam Central Highlands. Mitteilungen Deutsche Gesellschaft für allgemeine und angewandte Entomologie, 20: 133138.

* I conducted all experiments and prepared the manuscript, for which I am the corresponding author. 


\title{
Pyrophilous Insects in Vietnam Central Highlands
}

\author{
Thi Phuong Hoang, Stefan Schütz
}

Thi Phuong Hoang, Georg-August-Universität Göttingen, Abteilung für Forstzoologie und Waldschutz, Büsgenweg 3, DE-37077 Göttingen, Deutschland; E-Mail: phuongnfsgmail.com

\begin{abstract}
Pyrophile Insekten werden vom Feuer angezogen, insbesondere von Rauch und Hitze. Sie haben besondere Strategien entwickelt, um in Gebieten mit häufigen Bränden zu überleben. Diese Insekten wurden bereits in Europa, Amerika und Australien untersucht, aus Vietnam liegen bisher keine Daten vor. Informationen zu Verbreitung, Verhalten und zum Einfluss dieser Insekten auf biogechemische Kreisläufe sind eine Voraussetzung, um die Bedeutung feuerliebender Insekten für die Ökosystemregeneration nach Buschfeuern und Waldbränden zu verstehen.

In dieser Studie soll das Vorkommen von pyrophilen Insekten in Gegenden mit hoher Waldbrandfrequenz untersucht werden. Die Untersuchung wurde während der Trockenperiode von November 2013 bis März 2014 in der Provinz Kon Tum (Zentralvietnam) durchgeführt. Zehn Plots wurden in jeweils drei unterschiedlichen Lebensräumen angelegt: Flächen ohne Feuer (Habitattyp I), frisch abgebrannte Flächen (Typ II) sowie Habitate, die ein Jahr zuvor abgebrannt waren (Typ III). Der Untersuchungszeitraum für jede Fläche betrug drei Wochen. Auf den Untersuchungsflächen wurden 45 Insektenarten nachgewiesen, darunter sechs Arten mit pyrophilem Habitus. Zwei pyrophile Käferarten wurde im Habitat-Typ II in noch warmer Asche nachgewiesen, umgeben von glimmenden Holzresten, eine andere Art (Gonocephalum bilineatum) ein bis zwei Tage nach Erlöschen der Glut am Rande eines Lagerfeuers. Drei weitere Arten (Lanelater robustus, Ceropria laticollis und Promethis sp. 1) wurden häufig und ausschließlich in den Habitat-Typen II und III gefunden.
\end{abstract}

Stichworte: Pyrophile Insekten, Waldbrände, Insektenfangmethoden, Kon Tum. 


\subsection{Introduction}

Fires and insects are essential components of the forest ecosystem and often causally related. Insect outbreak may determine extent and intensity of subsequent fires by accumulation of fuels (Stocks 1987). Fires can affect insects by killing them directly or alter vital components of their habitat (McCullough et al., 1998). The abundance and spatial-temporal continuity of plant species during habitat recovery after fires are altered. This may later on specify the quality of plants in altered habitats as new hosts for immigrating herbivorous insect species (McCullough et al., 1998; Johansson et al., 2010). Some insect species, however, are attracted directly by fires for mating, oviposition, and re-colonizing. This might result in different communities of insects in this naturally cleared habitat. Fire cleared habitats provide favorable micro climate for these insects and create open space where insects can access easily and natural enemies are reduced (Wikars 1997; Esseen 1997; Boulanger et al., 2010; Klocke, 2011). These insects are called "pyrophilous insects" or "fire loving insects" which respond to smoke and heat generated by forest fires (Saint-Germain et al., 2005) and develop their own strategies in frequent fire areas for surviving or recolonizing (McCullough et al., 1998). They can be obligatory pyrophilous or facultative pyrophilous insects. The obligatory pyrophilous insects are specialized insect species which depend on frequent fires (Schütz et al. 1999; Suckling et al. 2001; Wikars 2001B; Schmitz et al. 2002; Allison et al. 2004; Evans 2010; Paczkowski et al. 2013, 2014) for reproduction and offspring, for example (Melanophila acuminata, Acanthocnemus nigricans). They colonize burnt trees and feed on heated wood (Evans, 1964; Schütz et al. 1999; Schmitz et al. 2002; Kreiss et al. 2007; Paczkowski et al. 2013, 2014) and fast-growing post-fire fungi (Heliövaara \& Väisänen 1983; Coulianos 1989; Wikars 1992; Wikars 2001A) as specialists mostly without inter-specific competition. Facultative pyrophilous insects re-colonize freshly burnt areas as a new habitat for mating, ovipositing and reproducing in high numbers utilizing fire-debilitated trees (Saint-Germain et al., 2008; Boulanger et al. 2010) and can be found in the ashes and beneath the bark of fire debilated trees acting as herbivores, fungivores, and as carnivores such as Pterostichus adstrictus, Notiophilus biguttatus, Harpalus quadripunctatus, and Bembidion lampros (Coleoptera: Carabidae) (Gongalsky et al. 2006). They can be attracted to the newly created habitat, but may not be obligatorily dependent on fires, because they also appear in unburnt habitats (Wikars 1997; Wikars \& Schimmel 2001). Pyrophilous insects were observed amongst the Diptera, Lepidoptera, Coleoptera and Heteroptera (Wikars 1997). Up to now, 50 species of pyrophilous insects have been termed and can be seen more frequently after forest fires on the burnt areas than on neighboring unburnt areas (Wikars 1997). About $50 \%$ of the known pyrophilous 
species so far appear while a fire is still burning and interpenetrate the freshly burnt area (Wikars 1997).

Fire-loving insects have been examined in Europe, America, and Australia. Data on these insects in Vietnam, however, are not available to us yet. Information on presence, behavior, and their effect on biogeochemical cycles are needed to assess their possible impacts on forest ecosystem recovery after natural and anthropogenic fires. These data are essential to address biodiversity aspects as their roles in re-establishing biodiversity in fire prone forest ecosystems. Besides, nature protection can use data on these insects to assess their ability to mitigate the destructive consequences of frequent anthropogenic fires. Research on fire-loving insects also reflects the effect of fires, positive and negative, on the overall insect community diversity.

\subsection{Study site and experimental design}

In order to examine pyrophilous insects in Vietnam, study sites were selected in secondary forested areas and Pinus plantations adjacent to secondary forest in Kon Tum province of Vietnam Central Highlands. Selected areas within Kon Tum province included the districts of Sa Thay, Ngoc Hoi (where Chu Mom Ray National Park is located), Dak Ha district, in the Ngoc Linh protected area, which is situated in the districts of Dak Glei, and in the Ngoc Reo commune. The study was implemented during the dry season from $20^{\text {th }}$ of November 2013 to $28^{\text {th }}$ of February 2014, when forests were usually burnt and frequent fires were taking place, both of natural and anthropogenic origin.

Ten plots were placed on each study site at three different habitats, including unburnt ones (habitat type I), freshly burnt ones (1-6 days, habitat type II) and habitats burnt one year ago (habitat type III) (Tab. 1). Each study site was sampled over three weeks. Selected sites had a central area of $140 \mathrm{~m} \times 140 \mathrm{~m}$ and preferably larger, to allow space for a core circle of traps (Fig. 3). Habitat type I was selected to provide undisturbed reference areas for control samples. Habitat Type III was selected to check for the pyrophilous insects which were successfully developing in burnt logs, fire damaged trees, tree bark etc. Additionally, these areas attracted insects for re-colonization of re-growing plants. Habitat Type II was selected to check for the pyrophilous insects which were successfully attracted to the fire 1) for mating and ovipositing on plants and fungi, 2) scavenging and oviposition on carrion caused by animals not being able to escape the fire, and 3) predating or parasitizing on the former two groups. Approximately 43 different insect species were collected at these study sites during a period of three months using UV light trap, malaise traps and opportunistic search methods (search for presence on burnt logs, fresh ashes, and in smoke plumes). 
Trapping was conducted in a randomized block design, with three blocks arranged in a northsouth line according to wind direction. Block 1 was placed in the plot core circle using UV light trap. Block 2 situated in the furthest south using $1^{\text {st }}$ malaise trap and block 3 located in the furthest north using malaise trap $2^{\text {nd }}$. Light trap was placed in the edge of the circle directed toward the center of the circle in order to attract insects from this site (Fig. 1). UV light traps were suspended $0.7 \mathrm{~m}$ above ground and used for all types of habitat. Canopy Malaise traps from Santee Traps (Lexington, KY) were used with or without color panels for habitat type II and III. Canopy Malaise traps differed from the traditional Malaise trap in that an insect could be caught from any direction and the traps had collecting containers at the top and bottom. The Malaise trap measured approximately $2.7 \mathrm{~m}$ in height and $1.2 \mathrm{~m}$ in width. Three-meter tall, metal conduit poles were used to suspend the traps. A $0.5 \mathrm{~m}$ length of pipe with a larger diameter than the conduit was inserted into the ground and the trap support poles were then inserted into the metal pipe to hold the trap in place. Collecting containers were filled approximately one-third full with a soapy (Company Clear, Vietnam) water solution. The colored Malaise traps had four panels $\left(0.3 \mathrm{~m}^{2}\right.$ each) hung directly onto trees. Samples from malaise traps were immediately stored in $50 \%$ alcohol, sorted to morphologically similar groups and identified. Malaise traps were employed on one evening and 2 days at each study site and then transferred to other study sites. UV light trap was used over a 4 hours period primarily from $18 \mathrm{~h}$ to $22 \mathrm{~h}$. This trapping setup was moved to other selected habitat every night. At the end of each trapping period UV-collected insects were transferred to plastic boxes, killed with ethyl acetate and stored in ethanol $50 \%$.

\subsection{Results}

The total of 45 species was found. Two species (Coleoptera, unidentified 1,2) of the target beetles were found only in the habitat type II in the warm ashes close to smoldering logs and stumps in the freshly burnt habitat 150 m northeast of the Chu Mom Ray National Park and in the south of the Pinus plantation in C2 area of Sa Thay district. One species (Gonocephalum bilineatum Walker, 1858) (Coleoptera, Tenebrionidae) was captured one to two days after the forest fire in the ashes adjacent to smoldering logs and to cooking fires. This species was found only in habitat type II and III outside of the C2 Pinus plantation. Three other species (Lanelater robustus (Elateridae), Ceropria laticollis (Tenebrionidae) and Promethis sp. 1 (Tenebrionidae)) were frequently found in habitat type II and III.

Insect species caught by Malaise traps were mainly Coleoptera and Diptera in habitat burnt one year ago. These species were not caught by malaise traps in recently burnt habitats (Tab. 2). 
All beetles of these species were kept in plastic containers $(5 \mathrm{~cm}$ high, $6 \mathrm{~cm}$ diameter $)$ with peanut and water diet at $(25 \pm 1){ }^{\circ} \mathrm{C}, 40 \%$ relative humidity and a 12/12 day/night period for 1 week. Fourty-three species were caught in habitat type I and had been killed with ethyl acetate and stored in ethanol $50 \%$.

\subsection{Discussion}

About 600 beetles of each two species Coleoptera (Acanthocnemus nigricans) and (Coleoptera, unidentified 1) were found only in the warm ashes close to smoldering logs and stumps in the habitat type II. Three hundred and five Gonocephalum bilineatum were caught close to hot spots such as freshly charred wood and smoldering logs releasing smoke on freshly burnt areas. One hundred and fifteen Gonocephalum bilineatum together with 8 Lanelater robustus, 34 Ceropria laticollis and 63 Promethis sp.1, were found under the bark of the burnt trees on habitat burnt one year ago. Insects caught at the mentioned hot spots are considered as pyrophilous insects. Insects caught below the bark of the burnt trees were regarded as potentially pyrophilous insects. In order to rule out if the potential pyrophilous insects are attracted just by light, visible light traps and UV traps were examined. None of the pyrophilous beetles were caught in these traps. Moreover, none of the potentially pyrophilous insects were caught in visible light, UV traps, and Malaise traps. These beetles are probably attracted by more fire-specific stimuli like infrared radiation and fire-specific volatiles. Thus, developing suitable type of traps might be necessary to catche pyrophilous insects.

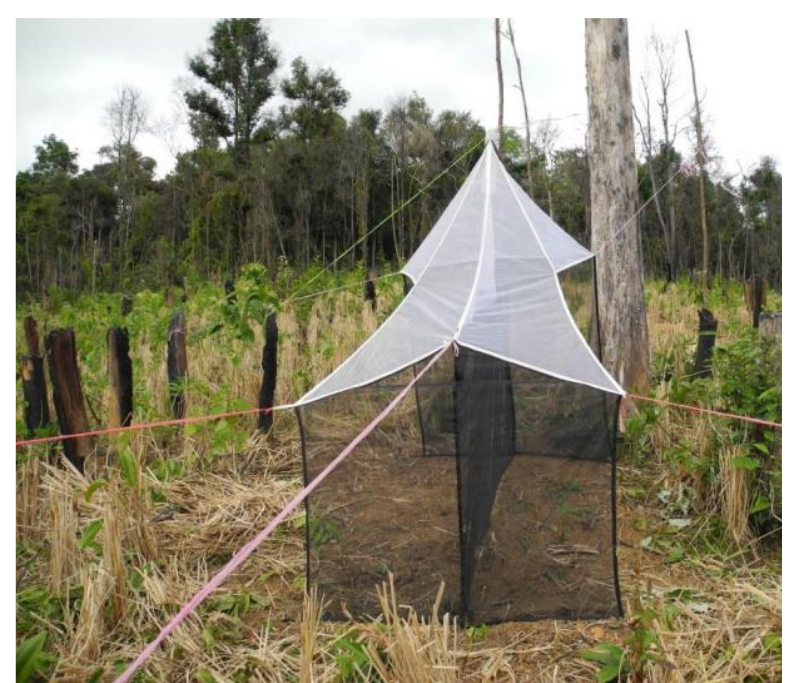

Figure 1: Malaise trap in habitat type III.

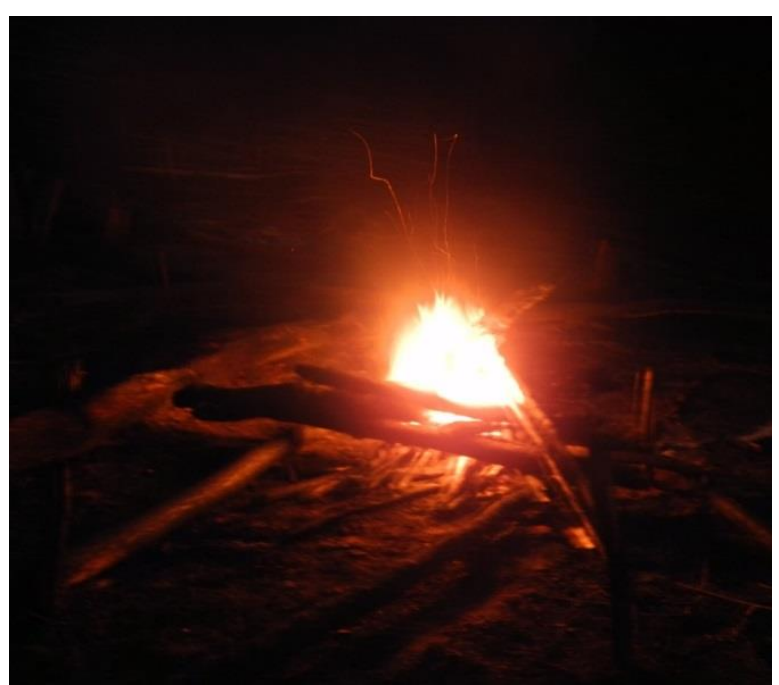

Figure 2: Burning logs in habitat II. 
Table 1: Number of potentially pyrophilous insects caught in different habitat types.

\begin{tabular}{|l|c|c|c|}
\hline & $\begin{array}{c}\text { Habitat type I } \\
\text { (Unburnt } \\
\text { habitat) }\end{array}$ & $\begin{array}{c}\text { Habitat type II } \\
\text { (Freshly burnt } \\
\text { habitat) }\end{array}$ & $\begin{array}{c}\text { Habitat type } \\
\text { III } \\
\text { (Habitat burnt } \\
\text { one year ago) }\end{array}$ \\
\hline Coleoptera (Acanthocnemus nigricans) & & 600 & \\
\hline Coleoptera (unidentified 1) & & 600 & \\
\hline Ceropria laticollis & & 305 & 115 \\
\hline Gonocephalum bilineatum & & & 8 \\
\hline Lanelater robustus & & & 63 \\
\hline Promethis sp.1 & & & \\
\hline
\end{tabular}

Table 2: Insect species caught by Malaise traps in habitat burnt one year ago in Vietnam Central Highlands, 2015.

\begin{tabular}{|c|c|c|c|}
\hline Order & Family & Species & $\begin{array}{l}\text { Number of } \\
\text { individual }\end{array}$ \\
\hline Hymenoptera & Apidae & Apis cerena Fabricius, 1793 & 2 \\
\hline Hymenoptera & Apidae & Trigona sp.1 & 5 \\
\hline Hymenoptera & Ichneumonidae & $\begin{array}{l}\text { Lissopimpla basalis (Vollenhoven, } \\
\text { 1879) }\end{array}$ & 2 \\
\hline Hymenoptera & Ichneumonidae & Flavopimpla sp. & 1 \\
\hline Hymenoptera & Ichneumonidae & Seticornuta sp. & 1 \\
\hline Hymenoptera & Ichneumonidae & Syzeuctus sp. & 2 \\
\hline Hymenoptera & Ichneumonidae & Enicospilus sp. & 1 \\
\hline Hymenoptera & Ichneumonidae & $\begin{array}{l}\text { Trathala flavoorbitalis (Cameron, } \\
\text { 1907) }\end{array}$ & 1 \\
\hline Hymenoptera & Aulacidae & Pristaulacus sp. & 2 \\
\hline Diptera & Agromyzidae & Agromyzid g. sp & 9 \\
\hline Diptera & Calliphoridae & Cosmina bicolor (Walker, 1856) & 1 \\
\hline Diptera & Calliphoridae & $\begin{array}{l}\text { Idiella mandarina (Wiedemann, } \\
1830 \text { ) }\end{array}$ & 1 \\
\hline Diptera & Calliphoridae & Isomyia chrysoides (Walker, 1856) & 1 \\
\hline Diptera & Calliphoridae & $\begin{array}{l}\text { Rhinia apicalis (Wiedemann, } \\
\text { 1830) }\end{array}$ & 9 \\
\hline Diptera & Calliphoridae & $\begin{array}{l}\text { Stomorhina discolor (Fabricius, } \\
\text { 1794) }\end{array}$ & 15 \\
\hline Diptera & Calliphoridae & $\begin{array}{l}\text { Stomorhina siamensis Kurahashi } \\
\text { et Tumrasvin, } 1992\end{array}$ & 1 \\
\hline Diptera & Chamaemyidae & Chamaemyid g. sp. & 1 \\
\hline
\end{tabular}




\begin{tabular}{|c|c|c|c|}
\hline Diptera & Conopidae & Conopid $g . s p$ & 1 \\
\hline Diptera & Culicidae & Culicid g. sp. & 1 \\
\hline Diptera & Dolichopodidae & Dolichopodid $g . s p$ & 5 \\
\hline Diptera & Ephydridae & Ephydrid $g . s p$. & 1 \\
\hline Diptera & Lonchaeidae & Lonchaeid $g . s p$. & 5 \\
\hline Diptera & Micropezidae & Micropezid $g . s p$. & 1 \\
\hline Diptera & Milichidae & Milichid g. $s p$. & 1 \\
\hline Diptera & Muscidae & Atherigona biseta Karl, 1939 & 16 \\
\hline Diptera & Muscidae & $\begin{array}{l}\text { Atherigona falcata (Thomson, } \\
\text { 1869) }\end{array}$ & 4 \\
\hline Diptera & Muscidae & $\begin{array}{l}\text { Dichaetomyia bibax (Wiedemann, } \\
1830 \text { ) }\end{array}$ & 1 \\
\hline Diptera & Muscidae & $\begin{array}{l}\text { Myospila lenticeps (Thomson, } \\
\text { 1869) }\end{array}$ & 1 \\
\hline Diptera & Muscidae & Pygophora sp.3 & 3 \\
\hline Diptera & Muscidae & $\begin{array}{l}\text { Stomoxys calcitrans (Linnaeus, } \\
\text { 1758) }\end{array}$ & 2 \\
\hline Diptera & Muscidae & Stomoxys indicus Picard, 1908 & 1 \\
\hline Diptera & Phoridae & Phorid g. sp. & 1 \\
\hline Diptera & Platystomatidae & Platystomatid g. $s p$. & 1 \\
\hline Diptera & Sarcophagida & Metopia sauteri (Townsend, 1932) & 2 \\
\hline Diptera & Sarcophagida & $\begin{array}{l}\text { Miltogramma angustifrons } \\
\text { (Townsend, 1933) }\end{array}$ & 2 \\
\hline Diptera & Sarcophagida & Pierretia globovesica Ye, 1980 & 2 \\
\hline Diptera & Sarcophagida & $\begin{array}{l}\text { Taxigramma multipunctata } \\
\text { (Rondani, 1859) }\end{array}$ & 1 \\
\hline Diptera & Sepsidae & Sepsid g. sp. & 2 \\
\hline Diptera & Syrphidae & $\begin{array}{l}\text { Spheginobaccha demeijerei Van } \\
\text { Doesburg, } 1968\end{array}$ & 3 \\
\hline Diptera & Tachinidae & Tabanid $g . s p$. & 3 \\
\hline Diptera & Tephritidae & Tephritid g. sp. & 2 \\
\hline Diptera & Tipulidae & Tipulid $g . s p$. & 1 \\
\hline
\end{tabular}




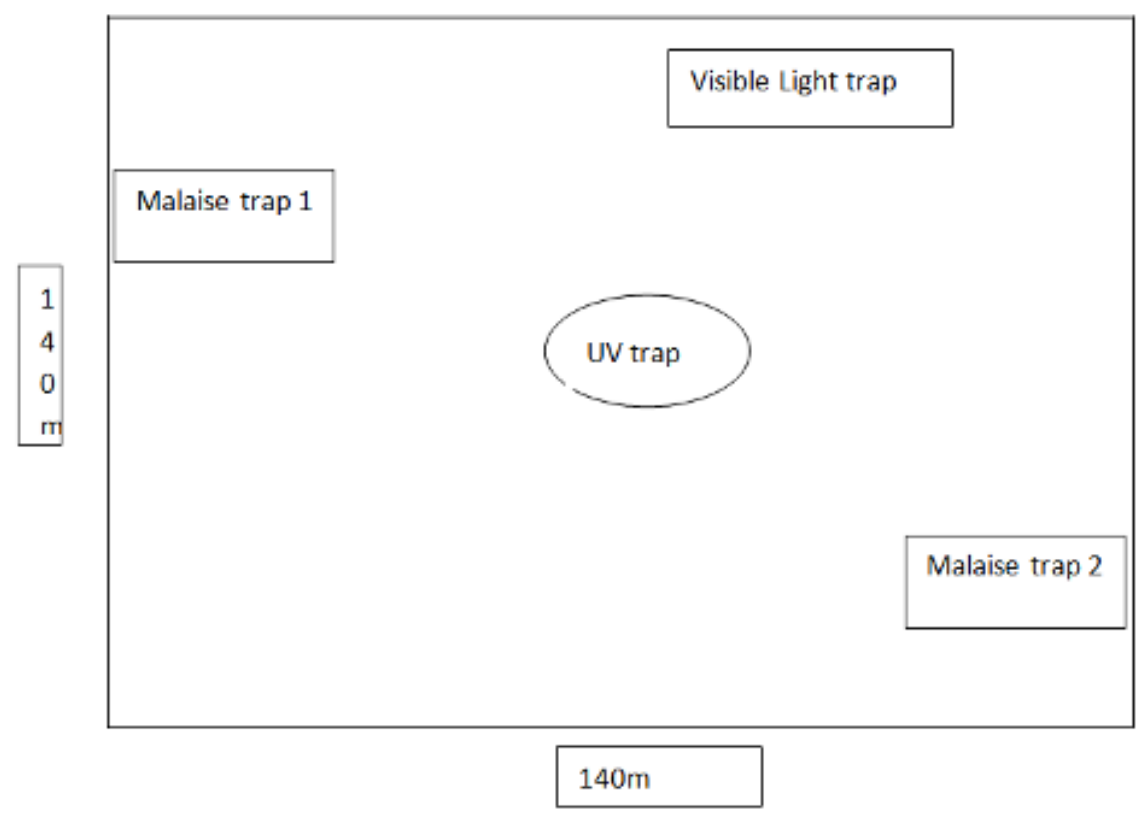

Figure 3: Study design.

It was demonstrated that some pyrophilous insects possess a special infrared organ (Evans 1964; Schmitz et al., 2000; Schmitz et al., 2008). Moreover, they may possess special adaptations in physiology and morphology of their antennae enabling them to perceive firespecific volatile organic compounds via their olfactory system (Schütz et al. 1999; Paczkowski et al. 2013, 2014). To examine their adaptations to the need to track down remote forest fires, further experiments and studies on the sensory organs of these species need to be conducted employing methods as Electronantennography (EAG), Gas Chromatography with Mass Spectrometry (GC - MS), and Scanning Electron Microscopy (SEM).

\subsection{Acknowledgements}

Insects were identified by specialists of the Department of Insect Systematics at the Institute of Biology and Ecological Resources, Hanoi, Vietnam. Helpful corrections by an anonymous reviewer are gratefully acknowledged. TPH is supported by a stipend from the KAAD. 


\subsection{References}

Allison, J. D., Borden, J. H., Seybold, S. J. (2004). A review of the chemical ecology of the Cerambycidae (Coleoptera). Chemoecology, 14(3-4): 123-150.

Boulanger, Y., Sirois, L., Hébert, C. (2010). Distribution of saproxylic beetles in a recently burnt landscape of the northern boreal forest of Québec. Forest Ecology and Management, 260(7): 1114-1123.

Coulianos, C. C. (1989). New provincial records of Swedish flatbugs and barkbugs (Hem. Het., Aradidae) with Aradus truncatus FIEBER, 1861, new to Sweden. Entomologisk tidskrift, 110(1-2): 53-57.

Esseen, P.-A., Ehnström, B., Ericsson and L., Sjöberg, K. (1997). Boreal forests. Ecology Bulletin 46: 16-47.

Evans, W. G. (1964). Infrared receptors in Melanophila acuminata De Geer. Nature (Lond.) 202: 211.

Evans, W.G. (2010). Reproductive role of infrared radiation sensors of Melanophila acuminata (Coleoptera: Buprestidae) at forest fires. Annals of the Entomological Society of America 103: 823-826.

Gongalsky, K.B., Midtgaard, F. and Overgaard, H.J. (2006). Effects of prescribed forest burning on carabid beetles (Coleoptera: Carabidae): a case study in south-eastern Norway. Entomologia Fennica 17(3): 325-333.

Heliövaara, K. and Väisänen, R. (1983). Environmental changes and the flat bugs (Heteroptera, Aradidae and Aneuridae). Annals Entomologia Fennica, 49: 103-109.

Johansson, T., Hjälten, J., Stenbacka, F. and Dynesius, M. (2010). Responses of eight boreal flat bug (Heteroptera: Aradidae) species to clear-cutting and forest fire. Journal of Insect Conservation, 14: 3-9.

Klocke, D. (2011). Fire-Adaptation in Hypocerides nearcticus Borgmeier and Anabarhynchus hyalipennis hyalipennis Marquart and new notes about the Australian "Smoke Fly" Microsania australis Collart (Diptera: Phoridae, Therevidae and Platypezidae). The Open Entomology Journal 5: 10-14.

Kreiss, E., Schmitz, H. and Gebhardt, M. (2007). Electrophysiological characterization of the infrared organ of the Australian "little ash beetle" Acanthocnemus nigricans (Coleoptera, Acanthocnemidae). Journal of Comparative Physiology, 193(7): 729-739.

McCullough, D.G., Werner, R.A., Neumann, D. (1998). Fire and insects in northern and boreal forest ecosystems of North America. Annual Reviews of Entomology, 43: 107-127.

Paczkowski, S., Paczkowska, M., Dippel, S., Schulze, N., Schütz, S., Sauerwald, T., et al. (2013). The olfaction of a fire beetle leads to new concepts for early fire warning systems. Sensors and Actuators, B: Chemical, 183, 273-282. 
Paczkowski, S., Paczkowska, M., Dippel, S., Flematti, G. and Schütz, S. (2014). Volatile combustion products of wood attract Acanthocnemus nigricans (Coleoptera: Acanthocnemidae). Journal of Insect Behaviour, 27: 228-238.

Saint-Germain, M., Larrivée, M., Drapeau, P., Fahrig, L. and Buddle, C. M. (2005). Shortterm response of ground beetles (Coleoptera: Carabidae) to fire and logging in a spruce dominated boreal landscape. Forest Ecology and Management, 112(1-3): 118-126.

Schmitz, H., Schmitz, A. and Horst, B. (2000). New type of infrared organ in the Australian "fire-beetle" Merimna atrata (Coleoptera: Buprestidae). Naturwissenschaften, 87: 542-545.

Schmitz, H., Schmitz, A., Trenner, S. and Bleckmann, H. (2002). A new type of insect infrared organ of low thermal mass. Naturwissenschaften, 89(5): 226-229.

Schmitz, A., Gebhardt, M. and Schmitz, H. (2008). Microfluidic photomechanic infrared receptors in a pyrophilous flat bug. Naturwissenschaften, 95(5): 455-460.

Schütz, S., Weißbecker, B., Hummel, H. E., Apel, K.-H., Schmitz, H. and Bleckmann, H. (1999a). Insect antenna as a smoke detector. Nature, 398: 298-299.

Stocks, B. J. (1987). Fire potential in the spruce budworm-damaged forests of Ontario. Forestry Chronicle, 63(1): 8-14.

Suckling, D. M., Gibb, A. R., Daly, J. M., Chen, X. and Brockerhoff, E. G. (2001). Behavioral and electrophysiological responses of Arophalus tristis to burnt pine and other stimuli. Journal of Chemical Ecology, 27(6): 1091-1104.

Wikars, L.O. (1992). Skogsbränder och insekter. Entomologisk Tidskrift, 133(4): 1-11.

Wikars, L.O. (1997). Effects of forest fire and the ecology of fire-adapted insects. Comprehensive Summaries of Uppsala Dissertations from the Faculty of Science and Technology 272. Acta Universitatis Upsaliensis, Uppsala, Sweden, 272 pp.

Wikars, L.-O. (2001a). The wood-decaying fungus Daldinia loculata (Xylariaceae) as an indicator of fire-dependent insects. Ecological Bulletins, 49: 263-268.

Wikars, L.-O. (2001b). Dependence on fire in wood-living insects: An experiment with burned and unburned spruce and birch logs. Journal of Insect Conservation, 6: 1-12.

Wikars, L.-O. and Schimmel, J. (2001). Immediate effects of fire-severity on soil invertebrates in cut and uncut pine forests. Forest Ecology and Management, 141: 189-200. 


\section{Chapter 3}

\section{Do volatiles released upon heating of different species of Vietnamese woody plants attract pyrophilous insects?}

This is a manuscript prepared for submission. I conducted all experiments and prepared the manuscript. 


\begin{abstract}
Volatile organic compounds (VOCs) released by burnt wood of the three Vietnamese tree species Pterocarpus macrocarpus, Lithocarpus ducampii and Parinari anamensis, and by the bamboo species Bambusa procera, were investigated upon heating at temperatures of $25^{\circ} \mathrm{C}$, $100^{\circ} \mathrm{C}, 150^{\circ} \mathrm{C}, 200^{\circ} \mathrm{C}, 250^{\circ} \mathrm{C}$ and $300^{\circ} \mathrm{C}$. The responses of pyrophilous insects to a mixture of four VOCs (hydroxyacetone, 5-methylfurfural, guaiacol, and 4-ethylguaiacol) were investigated in the field with traps baited with the VOCs. A total of 55 VOCs were released in notable amounts by the four woody species within this temperature range. These VOCs consisted of terpenoids, ketones, esters, furanes, pyrans, anhydrosugars, phenols, guaiacols, syringols, methoxybenzenes and naphthalenes. Thirty-five of the 55 compounds were released by at least one species at one temperature. In contrast to the other species, P. macrocarpus released a broad variety of sesquiterpenes. Fifty-five VOCs were emitted by this species over the tested temperature range. The other species released VOCs in notable amounts only at $250^{\circ} \mathrm{C}$ and $300^{\circ} \mathrm{C}$. Lithocarpus ducampii emitted 31 volatiles, while P. anamensis released 23 volatiles, and B. procera 14 volatiles. Field tests on burnt areas examining the attractiveness of traps baited with the VOCs resulted in 22 insect species belonging to the order of Coleoptera, of which only three species were caught by VOCs traps and hand collection. Ten insect species were captured only by VOC traps. Eight species were caught only by hand collection. The functional biodiversity of plant species seems to be associated with the chemo-diversity of fireinduced VOCs. This might play an essential role in the host plant selection of pyrophilous insects, thus linking plant diversity to the biodiversity of pyrophilous insects.
\end{abstract}

Keywords: Pterocarpus macrocarpus, Lithocarpus ducampii, Parinari anamensis, Bambusa procera, biodiversity, chemo-diversity, forest fires, burnt wood volatiles (VOCs), pyrophilous insects. 


\subsection{Introduction}

Pyrophilous insects have received much attention in recent years due to their ability to approach fires or freshly burnt areas from a far distance. One way to approach fires is that pyrophilous insects use their olfactory receptors (Schütz et al., 1999) which enable them to perceive volatile organic compounds (VOCs) released by burning plants during a forest fire (Paczkowski et al. 2014). VOCs emitted by burning or smoldering wood, therefore, play an essential role in the survival of pyrophilous insects. To select the right place for feeding, mating, oviposition and development, pyrophilous insects have to rely on chemical signatures indicating suitable spots for larval development. Signals of interest can be the presence of VOCs released during heating of wood at a fire starting point, for example at $200^{\circ}$ to $300^{\circ} \mathrm{C}$. Recent studies document the volatiles released by heating of wood during the process of thermal degradation of lignin and cellulose. For example, hydroxyacetone is released by thermal degradation of cellulose and 5methylfurfural is released by thermal degradation of hemi-celluloses (Mehmetli et al., 2008) and guaiacol and 4-ethylguaiacol released during thermal degradation of lignin. However, little attention has been paid to study the diversity of volatiles released during heating of different plant species.

Besides these studies on VOCs released during heating of wood, a few investigations focus on the olfactory perception of several burnt wood volatiles in pyrophilous insects such as the buprestid beetles Melanophila accuminata (Schütz et al., 1999), Melanophila cuspidata (Morimoto et al., 2006) and Merimna atrata (Paczkowski 2013). Furthermore, the perception and behavior of the (Geiser 2016) pyrophilous acanthocnemid beetle Acanthocnemus nigricans has been studied (Paczkowski et al. 2014). These studies showed that there are common burnt wood volatiles which are perceived by all insects and there are some burnt wood volatiles which are perceived only by one or 2 species of insects (Tab. 1). Therefore, the diversity of burnt wood volatiles might govern the chemo-diversity of pyrophilous insects. However, little evidence is available contributing to this.

Forest fires of anthropogenic origin took place in Vietnam with an average high number of 16,086 fires per year (2004 to 2012) where the Central Highlands are one of the most important fire hotspot (Le et al., 2014). The main causes of anthropogenic forest fires are shifting cultivation during illegal logging, and overexploitation of timber and non-timber forest products (McNamara et al., 2006). On the other hand, there is potential for a high diversity of pyrophilous insects in Vietnam (Hoang \& Schütz 2015; Geiser 2016). However, to the best of our knowledge, there is no study about the impact of burnt plant volatiles on the biodiversity of pyrophilous insects in this region so far. 
The main aims of this study are to examine the (potential) volatiles released by different Vietnamese woody species under controled condition and to assess the interplay between the biodiversity of pyrophilous insects and burnt wood volatiles in the field by employing traps baited with fire-specific volatiles.

For the wood heating experiment, we selected three different tree species and a bamboo species because these woody species are present abundantly in Vietnam, especially in areas of fire hotspot in the Central Highlands of Vietnam (Le 1996). They have different wood properties and ecological traits. Moreover, logging of these trees species contributed to forest fires. These tree species include Pterocarpus macrocarpus, Lithocarpus ducampii, Parinari anamensis, and a bamboo species Bambusa procera. Pterocarpus macrocarpus has very strong, first-class wood properties. It is used in construction, cabinet work, high-class furniture, and fine art articles. It growns in the well-drained, light textured and low humidity soils (Le 1996). The wood is heavy and highly resistant to termites and insects (Morimoto et al., 2006). Lithocarpus ducampii has durable wood properties. It grows on clay and sandy-clay soil and can protect and ameliorate the soil (Le 1996). It is used in construction to make beds, shutters and to build boats and ships (Le 1996). Lithocarpus ducampii grows in wet sandy or rocky soil (Le 1996). It is classified as a less durable timber. It can be used for furniture and as interior construction wood (Le 1996). L. ducampii grows in all types of soil, even in soil with poor nutrients (Le 1996). It is used as construction material, as a biofuel, in pulp and paper making and for plywood. Bambusa procera is a woody grass and an important non-timber forest product species.

For the biodiversity assessment study, we employed two traps baited with burnt wood volatiles and two empty control traps. The volatiles included hydroxyacetone and 5-methylfurfural, as these are characteristic products of the thermal degradation of cellulose (Piskorz et al., 1986; Flematti et al., 2004), guaiacol and 4-ethylguaiacol. These compounds are typical products of the thermal degradation of lignin (Branca et al., 2006; Azeez et al., 2010).

\subsection{Materials and methods}

\subsubsection{Wood samples}

Five different trunks $(20 \mathrm{~cm})$ of Pterocarpus macrocarpus, Lithocarpus ducampii, Parinari anamensis and Bambusa procera were sampled during the dry season in 2014 and 2015 in the Ngoc Reo forest, Kon Tum province, in the Central Highlands of Vietnam (Coordinates: Pterocarpus macrocarpus: N14³1'.912”, E10803'925”; Lithocarpus ducampii: N14³1'.930”, E10803'938”; Parinari anamensis: N14³1'.936”, E10803'927’; Bambusa 
procera: N14³1'.937’, E10803'929”). A permit for sampling was obtained from the provincial forest protection department of Kon Tum, Vietnam. Air-dried samples were collected from the middle part of xylem by slowly drilling with a wood driller $(\varnothing=5 \mathrm{~mm})$.

\subsubsection{Chemicals}

All solvents used for cleaning and eluting (methanol, dichloromethane, trichloromethane, and pentane) were of analytical quality (p.a.; Merck, Darmstadt, Germany). Authentic standard compounds were of 95 to $99 \%$ purity and are listed in Tab. S1 (appendix).

\subsubsection{Sampling of volatiles}

To study the volatile emissions of wood heated to different temperatures, a gas chromatography (GC) oven (Fractovap series 4160, Carlo Erba Instrumentazione, Rodano, Italy) was used as a heating chamber for controlled wood heating experiments. A glass flask (250 ml Duran, Schott AG, Mainz, Germany) was placed into the GC oven. Synthetic air $\left(20 \% \mathrm{O}_{2}\right.$ in $\mathrm{N}_{2}$, Alpha Gaz, Düsseldorf, Germany) was introduced into the flask at a pressure of 0.75 bar. The air was then removed from the flask using a rotary vane pump (Thomas Division, Sheboygan, USA) and pumped through a charcoal trap (1.8 mg Charcoal, CLSA Filter, Daumazan sur Arize, France) at a rate of 1.2 liters per minute $(1 / \mathrm{min})$. Before sampling of each volatile, a control sample of 0.6 liters of air from a clean flask maintained at $250^{\circ} \mathrm{C}$ for $30 \mathrm{~min}$ was collected using a charcoal trap for 30 seconds. Afterward, the flask was filled with a $1 \mathrm{~g}$ wood chip sample. After $10 \mathrm{~min}$ of conditioning at $25^{\circ} \mathrm{C}$ and an air flow of two liters per minute, the rotary vane pump removed 0.6 liters of a sample at a flow rate of $1.2 \mathrm{l} / \mathrm{min}$ through the charcoal trap. Afterward, the temperature was raised to $100^{\circ} \mathrm{C}$ and held for $10 \mathrm{~min}$ at an airflow of $2 \mathrm{l} / \mathrm{min}$; then, the next charcoal trap was connected for 30 seconds to the rotary vane pump. A 0.6-liter sample was extracted at a flow rate of $1.2 \mathrm{l} / \mathrm{min}$ through the charcoal trap. This procedure was repeated at $150,200,250$ and $300^{\circ} \mathrm{C}$ to collect the volatiles from wood chips heated to different temperatures.

\subsubsection{Trace analysis}

A mixture of $100 \mu \mathrm{l}$ of dichloromethane/methanol (2:1) was used to elute the charcoal traps. One microliter of the eluate was injected by a type 7163 auto sampler in the pulsed splitless mode (pulse pressure $150 \mathrm{kPa}$ at $1.5 \mathrm{~min}$ ) at a temperature of $250^{\circ} \mathrm{C}$ into a split/splitless injection port of a $6890 \mathrm{~N}$ Network GC System with a $30 \mathrm{~m} \times 0.25 \mathrm{~mm}$ HP-5 MS $(95 \%$ Dimethyl - 5\% Diphenyl-Polysiloxane) nonpolar column (0.25 $\mu \mathrm{m}$ film thickness), both from Agilent Technologies (Santa Clara, USA). The oven was programmed as follows: the initial 
temperature was $40^{\circ} \mathrm{C}$ for $2.5 \mathrm{~min}$, then increased at a rate of $6.2^{\circ} \mathrm{C}$ per min to $250^{\circ} \mathrm{C}$ and finally held for $10 \mathrm{~min}$. Helium of $99.999 \%$ purity was used as the carrier gas. The carrier gas flow was adjusted to $1 \mathrm{ml} / \mathrm{min}$ resulting in a gas vector of $24 \mathrm{~cm} / \mathrm{s}$. A quadrupole mass spectrometer (type 5973, Agilent Technologies, Santa Clara, USA) with electron impact ionization $(70 \mathrm{eV})$ linked to the $\mathrm{GC}$ by a transfer line at $250^{\circ} \mathrm{C}$ was operated in the scan mode in a detection range of $\mathrm{m} / \mathrm{z}=20-354$ atomic mass unit (amu) with an acquisition time of 0.5 seconds.

Data acquisition was performed using MS ChemStation software (Agilent). Peaks were identified with the National Institute of Standards and Technology mass spectral library (NIST, Gaithersburg, USA), the MassFinder 2.1 software and the library "Terpenoids and Related Constituents of Essential Oils” (Hochmuth, König, Joulain, Hamburg, Germany). The linear retention index was calculated using straight-chain hydrocarbons (C7-C24). The co-elution of authentic standards was used to confirm the identity of the compounds.

For quantification purposes, a 100ng external standard was used for each class of wood degradation product utilizing a-two point calibration curve. Furfural was used for polysaccharide degradation products, guaiacol was used for lignin degradation products, and $\alpha$-humulene was used for sesquiterpenes (cf. Tab. S1). The release rate was calculated from the quantity in the sample, sampling time, and sample dry mass at the beginning of the experiment as the respective release rate equivalents. A compound was deemed present in the sample if it had a release rate equivalent greater than three $\mathrm{ng} / \mathrm{g}$ * s (a notable amount) because this level is thought to represent the detection limit of pyrophilous insect antennae (Evans 1966).

\subsubsection{Hand collection}

Four people performed the searches for insects in the smoldering logs at different burnt habitats where the wood samples were found (the exact locations were mentioned in chapter 2.1). Insects approaching smoldering logs were count and collected every 5 minutes for 2 hours over 3 times per day. The hand collection was done from 1 to 6 days at each burnt habitats where the wooden logs were burning and smoking.

\subsubsection{Field tests}

The field experiment was carried out in secondary forested areas in Ngoc Reo forest, Pinus plantations, adjacent to the secondary forest of Chu Mom Ray National Park and inside the national park (Sa Thay district, Kon Tum province, Vietnam Central Highlands). Mean temperature (2015) at the study area was $21.8^{\circ} \mathrm{C}$ during the investigation period (from February to April). Field research was conducted during the dry season from 20 February to 14 April 
2015, when forests were usually burnt and frequent fires were taking place, both of natural and anthropogenic origin.

Trap setup was placed on each study site at two different habitats, including unburnt and freshly burnt habitat (from 1 - 10 days after the fire).

An unburnt habitat was selected to provide an undisturbed reference area for control samples, whereas a freshly burnt habitat was chosen for investigating the presence of pyrophilous insects attracted to burnt wood. The trap setup was installed in a square block design, with three blocks arranged in a north-south line according to wind direction. The square had a central area of at least $300 \mathrm{~m} \times 300 \mathrm{~m}$ to allow space between traps (Fig. 1). To prevent down-wind effects, the first VOC trap was placed in the furthest southeast, $50 \mathrm{~m}$ away from the edge. The second VOC trap was installed in the furthest southwest, also $50 \mathrm{~m}$ apart from the edge. These two VOC traps were filled with the total of $6.2 \mathrm{ml}$ of a mixture of characteristic fire VOCs to test for behavioral activity including $(2 \mathrm{ml})$ Hydroxyacetone, $(2 \mathrm{ml}) 5$-methylfurfural, $(2 \mathrm{ml})$ guaiacol and $(0,2 \mathrm{ml}) 4$-ethylguaiacol with the proportion of 1:1:1:1/10, respectively. Due to the limited amount, we could only provide the proportion of 4-ethylguaiacol $1 / 10 \mathrm{ml}$ on this mixture. The VOCs were renewed every day. Two control traps were set up in the furthest northeast and northwest respectively. These traps were suspended $1 \mathrm{~m}$ above ground and used in both habitat types. Each trap was active for 15 hours per day from 6:00 to 22:00 hours over 10 days resulting in a total of 11 replicates. After each day, the VOC mixture was renewed. Every second day traps were placed on a new site. Insects were monitored every three hours and captured specimens were transferred to plastic boxes. Insects were sorted to morphologically similar groups and killed with ethyl-acetate before being labeled and stored in 50\% ethanol. Specimens from both traps and hand collection were sent to the Department of Insect Systematics at the Institute of Ecology and Biological Resources (IEBR) in Hanoi, Vietnam, for identification. 


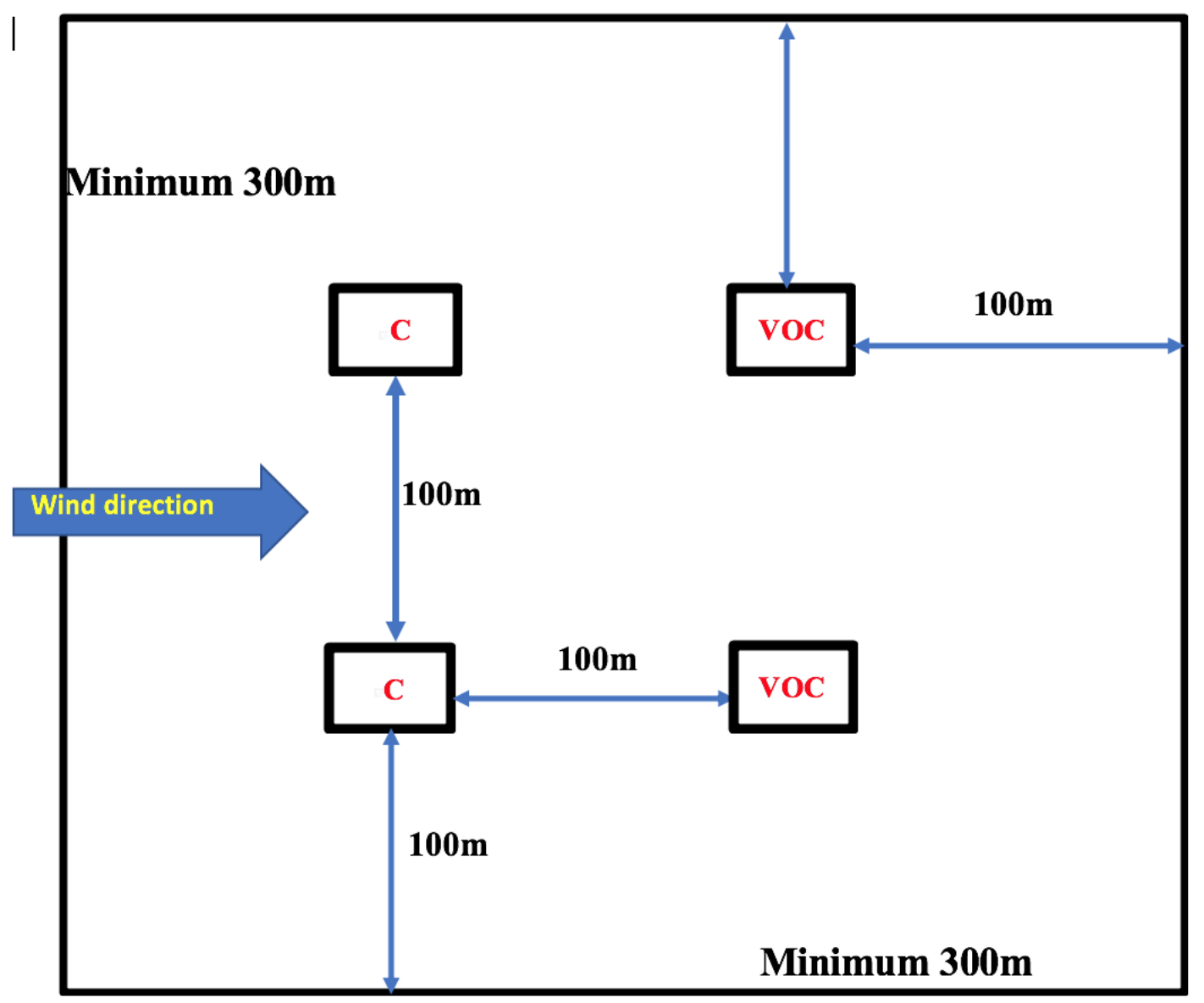

Figure 1: Symmetric drawing of the study design in the study areas in Vietnam central Highlands in 2015. C: Empty control traps. VOC: traps baited with a mixture of fire-specific volatile organic compounds.

\subsubsection{Statistical analysis}

The quantities of volatiles released by the woody plant species were tested for a normal distribution using the Shapiro-Wilk test. The data did not show a normal distribution. Therefore, the Wilcoxon rank sum test was used to test for significant differences in the emission rates of the volatiles. RStudio (version 3.2.0 [2015-04-16]) open source software was used for the statistical analysis. The significance level (P) was set at $95 \%$.

\subsection{Results}

\subsubsection{Trace analysis}

A total of 65 compounds was identified to be released by the four woody species. Ten terpenoids were released only by Pterocarpus macrocarpus at a temperature range from $25^{\circ} \mathrm{C}$ to $200^{\circ} \mathrm{C}$ including $\alpha$-copaene, $\alpha$-cubebene, $\alpha$-guaiene, $\beta$-selinene, $\alpha$-muurolene, $1,2,4 \mathrm{a}, 5,6,8 \mathrm{a}$ hexahydro-4,7-dimethyl-1-(1-methylethyl)-naphthalene, guaia-1(10),11-diene ( $\delta$-guaiene), $\alpha$ amorphene, $\gamma$-cadinene, tau-cadinol. 
All four woody species released 55 compounds in notable amounts $\left(0.003 \mu \mathrm{g} / \mathrm{g}^{*} \mathrm{~s}\right)$ at $250^{\circ} \mathrm{C}$ and $300^{\circ} \mathrm{C}$ (Tab. S1 and Fig. 1) with different concentration (Fig. 2). $\alpha$-caryophyllene, aromadendrene, and $\alpha$-calacorene were emitted at all temperatures in Pterocarpus macrocarpus (Tab. 1). All other compounds were emitted at specific temperatures by each of the four woody species. These compounds belonged to 11 different structural groups, including terpenoids, ketones, esters, furanes, pyrans, anhydrosugars, phenols, guaiacols, syringols, methoxybenzenes and naphthalenes.

Five of 55 volatiles are commonly released reliably (minimum $>0 \mu \mathrm{g} / \mathrm{g}^{*} \mathrm{~s}$ ) by all four woody species either at $250^{\circ} \mathrm{C}$, at $300^{\circ} \mathrm{C}$ or both temperatures (Tab. 1). These volatiles included hydroxyacetone, furfural, 1-(2-furanyl)-ethanone, 5-methylfurfural, and levoglucosenone.

Thirty-four of 55 volatiles were found consistently with a quantity higher than 0 in at least one woody species at one temperature. These compounds were emitted during thermal degradation of cellulose and lignin or during the evaporation and thermal oxidation of sesquiterpenes (Fig. 2 and Tab. S1).

Twenty compounds were species-specific volatiles released only by $P$. macrocarpus at both temperatures including 2-cyclohexen-1-one, 3-methyl-2,5-furandione, 2-hydroxy-1-methoxyethylfuran, phenethyl ester acetic acid, 2-hydroxy-3-methyl-2-cyclopenten-1-one, 2-hydroxybenzaldehyde, 1-acetyl-(1H)-imidazole, $\alpha$-caryophyllene (a-humulene), aromadendrene, cadina-1(10),6,8-triene, $\delta$-cadinene, 4-hydroxy-3-methoxy-benzoicacid methylester, $\alpha$ calacorene, unidentified compounds, tau-muurolol, 4-hydroxy-3,5-dimethoxy-benzaldehyde, cadalene, 10-nor-calamenen-10-one. Four volatiles were released specific by $L$. ducampii including 1-(acetyloxy)-2-propanone, butyrolactone, 2-methoxy-3-methyl-phenol, 1,5dimethyl-naphthalene. Five volatiles were released specific by $P$. annamensis, including 4methylphenol; 1,2,3,4-tetrahydro-1,5,7-trimethyl-naphthalene, 3-methoxy-5-methylphenol, 3hydroxy-4-methoxybenzoic acid, and 3-(2-naphthyl)-1-butene.

Seven compounds showed temperature dependency. Two compounds were released only by $P$. macrocarpus at $250^{\circ} \mathrm{C}$ including $\gamma$-terpinene, and at $300^{\circ} \mathrm{C}$ including 2,2-dimethyl-1,3cyclopentanedione. Three compounds were released only by L. ducampii at $250^{\circ} \mathrm{C}$ including 1,2-dihydro-1,1,6-trimethyl-naphthalene, 2,6-dimethyl-naphthalene, trans-isoeugenol. Two compounds were released only by $\mathrm{B}$. procera at $300^{\circ} \mathrm{C}$ including 1-(2-furanyl)-ethanone, levoglucosenone (Fig. 2 and Tab. S1). 


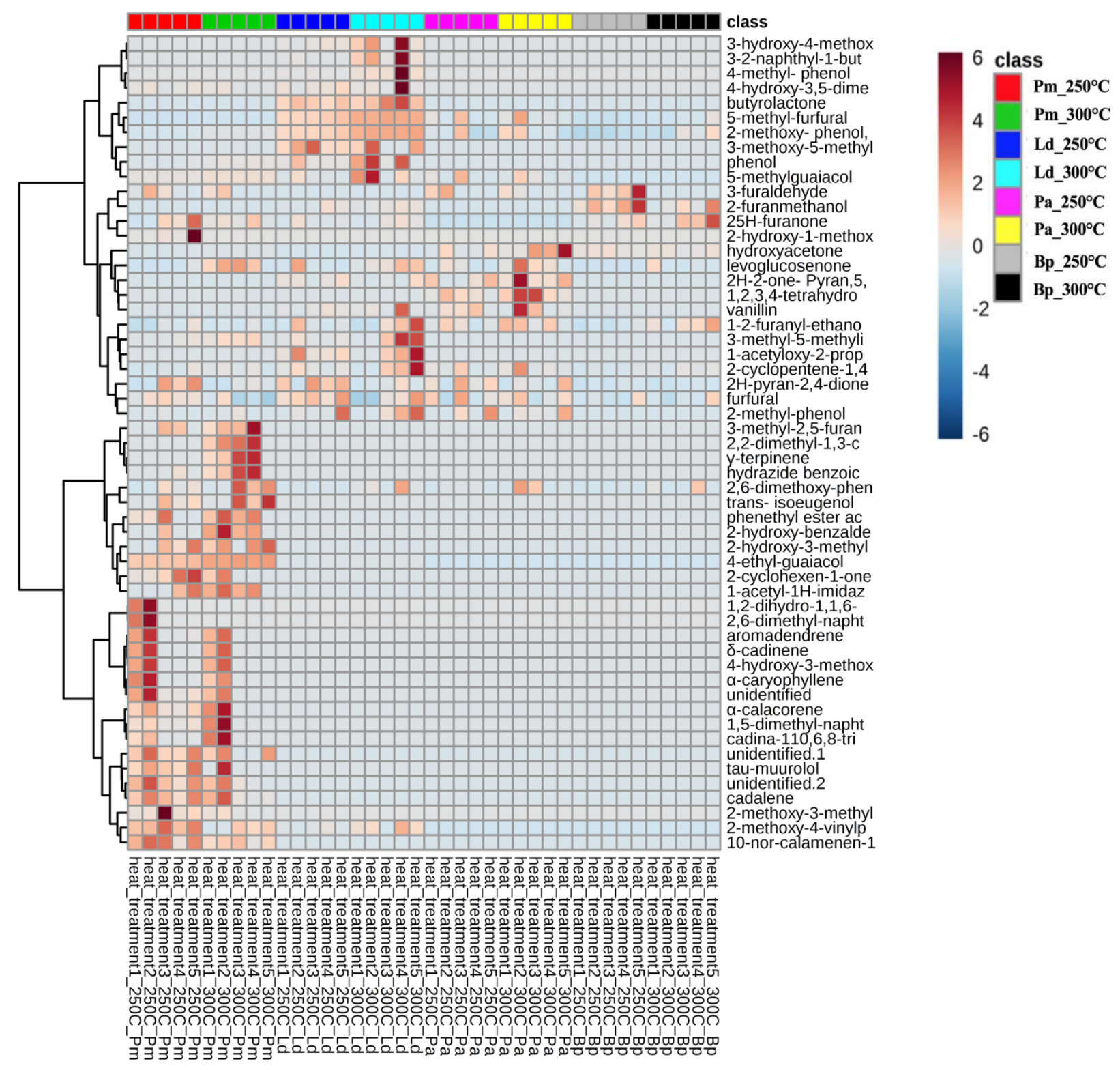

Figure 2: The heat map shows the concentration of VOCs released by all four woody species at $250^{\circ} \mathrm{C}$ and $300^{\circ} \mathrm{C}$; Pm: Pterocarpus macrocarpus, Ld: Lithocarpus ducampii, Pa: Parinari annamensis, Bp: Bambusa procera. The full name of the compounds is shown in Tab. S1. Dark to light blue: these VOCs are not found in this temperature. Light red to dark red: VOCs are found from low to high concentration.

\subsubsection{Field trial results}

Twenty-two species belonging to the orderColeoptera were caught by both VOCs traps and at smoldering logs (Fig. 3). However, only two species were caught in both VOC traps as well as by searching in smoldering logs including Apristus sp. 1, and Staphylinus sp. 3.

Twelve of the 22 species were caught only by VOCs traps including Anthicus sp. 1, Perissus rayus, Anthicoclerus sp. 1, Cartodere sp. 1, Litargus sp. 1, Litochrus sp. 1, Cryphalus sp. 1, Cryphalus sp. 2, Wallacellus denticulus, Eleusis humilis, Staphylinus sp. 2 and Anacypta sp. 1. These species showed statistically significant differences between the VOCs trap and control trap (Fig. 3). None of the insects caught by other traps was found in the control traps. Equally, 
the control traps in burnt habitats recorded insect species which were not found in other trap types such as Salganea sp. (Blattodea, Blattidae), Catapiestus sp. (Coleoptera, Tenebrionidae), Xylocopa confusa (Perez, 1901) (Hymenoptera, Apidae). Similarly, a different composition of insect species was recorded in these traps in unburnt habitat when compared to burnt habitat such as Demonax bowringii (Pascoe, 1859) (Coleoptera, Cerambycidae), Chlorophorus quatourdecimmaculatus (Chevrolat, 1863) (Coleoptera, Cerambycidae), Laius sp. (Coleoptera, Melyridae), Anomala russiventris (Fairmaire, 1893) (Coleoptera, Scarabaeidae), Anomala sp. (Coleoptera, Scarabaeidae) and Apis cerena (Fabricius, 1793) (Hymenoptera, Apidae).

Eight of the 22 species were found only during searching in smoldering logs in freshly burnt habitat including Acanthocnemus nigricans (Hope, 1843), Xylopsocus sp. 1, Monomma sp. 1, Hoshihananomia sp. 1, Elacatis sp. 1, Xyleborus exesus Blandford, Silvanus lewisi and Uleiota sp. (Fig. 3).

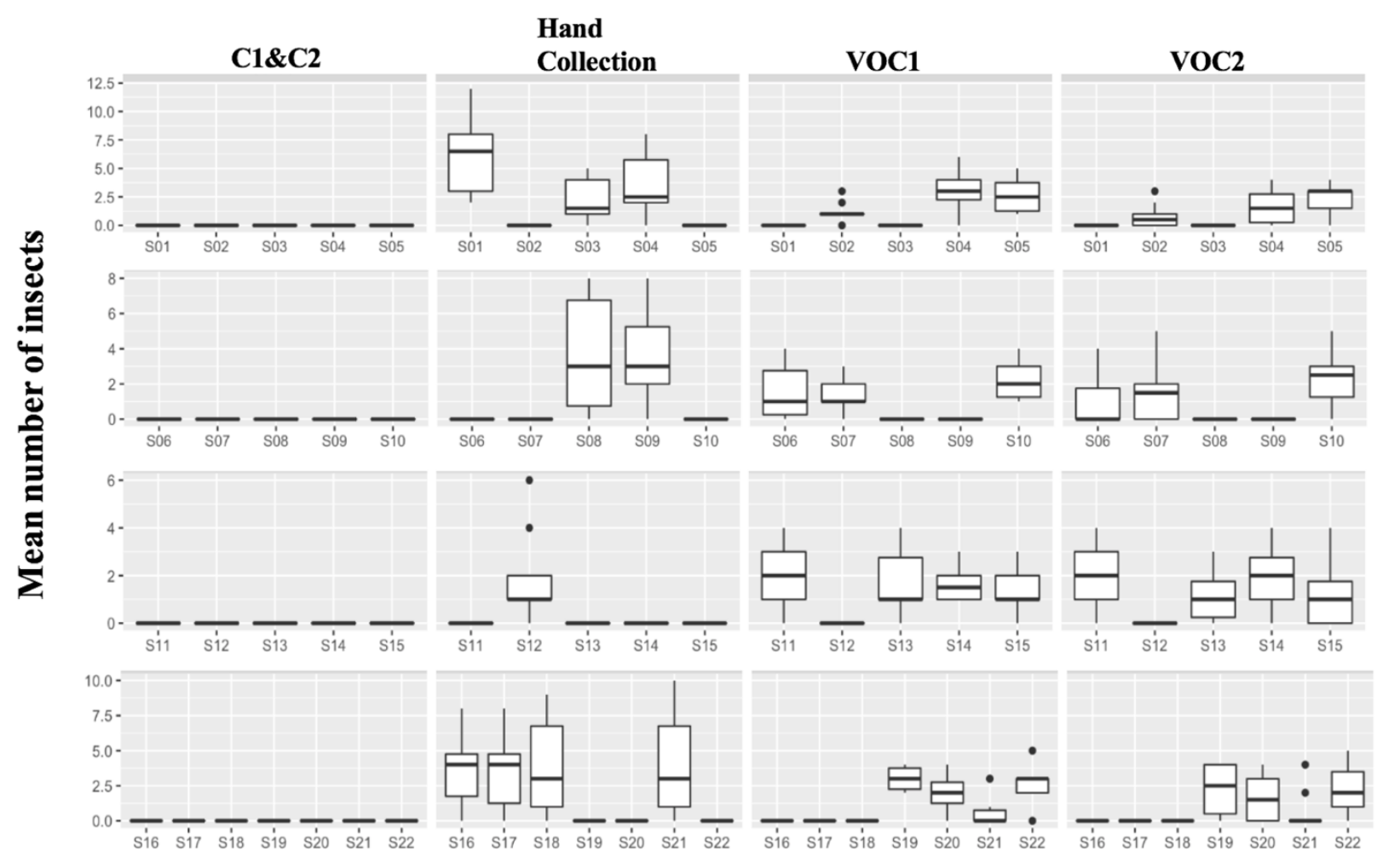

Insect species ID

Figure 3: The mean number of insect species (Order Coleoptera) caught by different traps ( $\mathrm{n}=10)$ : C1\&C2: control trap 1\&2, Hand collection: insects caught by searching in smoldering logs on burnt sites. VOC1: volatile trap number 1, VOC2: volatile trap number 2. Insect species ID: the full name of the insect species (all Coleoptera) is given below:

S01: Acanthocnemus nigricans (Acanthocnemidae) (Hope, 1843), S02: Anthicus sp. 1 (Anthicidae), S03: Xylopsocus sp. 1 (Bostrichidae), S04: Apristus sp. 1 (Carabidae), S05: Perissus rayus (Cerambycidae), S06: 
Anthicoclerus sp. 1 (Cleridae), S07: Cartodere sp. 1 (Lathridiidae), S08: Monomma sp. 1 (Monommidae), S09: Hoshihananomia sp. 1 (Mordellidae), S10: Litargus sp. 1 (Mycetophagidae), S11: Litochrus sp. 1 (Phalacridae), S12: Elacatis sp. 1 (Salpingidae), S13: Cryphalus sp. 1 (Scolytidae), S14: Cryphalus sp. 1 (Scolytidae), S15: Wallacellus denticulus (Scolytidae), S16: Xyleborus exesus Blandford (Scolytidae), S17: Silvanus lewisi (Silvanidae), S18: Uleiota sp. 1 (Silvanidae), S19: Eleusis humilis (Staphylinidae), S20: Staphylinus sp. 2 (Staphylinidae), S21: Staphylinus sp. 3 (Staphylinidae), and S22: Anacypta sp. 1 (Trogossitidae).

\subsection{Discussion}

\subsubsection{Burnt wood volatiles}

One of the primary goals of our study was to examine the volatiles released upon heating by wood samples of different Vietnamese tree species. As expected, our data demonstrates the diversity of the burnt wood volatiles released by different plant species. Besides the common volatiles released by all plant species in our study, we found that the specific release of sesquiterpene-derived and phenolic extractives by Pterocarpus macrocarpus is an outstanding feature in comparison with other woody species. Bamboo stands out because no extractivederived compounds were released upon heating and it showed a comparatively low diversity of lignin breakdown products (Tab. 1 and Fig. 1).

The common burnt plant VOCs found in our study are in line with previous studies. Paczkowski et al. (2013), for example, described VOCs released during thermal degradation of wood chips, cellulose, and lignin of P. sylvestris. These VOCs are commonly released during thermal oxidation of hemicellulose, cellulose, and lignin at temperatures between $200^{\circ} \mathrm{C}$ and $300^{\circ} \mathrm{C}$ in our study.

Moreover, our results showed five volatiles released by all woody species upon heating (Tab. 1 and Fig. 1) which is consistent with results obtained in previous studies, namely that these volatiles are released during the thermal degradation of hemicellulose and cellulose (Del Río et al., 1978; Guillen et al., 2000; Noudogbessi \& Yédomonhan 2008; De Simon et al., 2009; Paczkowski et al., 2013; Lourenço et al., 2015) including hydroxyacetone, furfural, 1-(2furanyl)-ethanone, 5-methylfurfural, levoglucosenone.

As cellulose and lignin structure vary between and within tree species, and even within individuals, species-specific volatiles vary enormously for each tree species as well (Kollmann 1982), also including different eucalyptus species (Maleknia 2009). Depending on the temperature, the more complex structure of hemicellulose and lignin chains are broken into small molecules and different VOCs. Temperature-dependent VOCs were also found in several 
eucalyptus species including E. cinerea, E. citriodora, E. nicholii and E. sideroxylon (Maleknia et al., 2009)

\subsubsection{Field tests}

One of the features of our research was to assess the local spectrum of pyrophilous insects. Our field tests demonstrate a certain diversity of insects caught by traps and by hand collection. As expected, pyrophilous insects approached the recently burnt areas (Wikars 1997) by perceived fire-specific VOCs (Schütz et al., 1999). Three hand- caught insect species in our study (Fig. 3) are attracted by VOCs. Moreover, they are not caught by VOCs traps in unburnt habitat and by control traps in both habitats.

Ten trap- caught insect species could only be caught by VOCs traps in freshly burnt habitats (Fig. 3). These species are putative pyrophilous insects because they obviously were lured to the traps by the fire-specific VOCs (Schütz et al., 1999) after having approached the recently burnt habitat (Wikars 1997; Schmitz et al., 2008). Furthermore, they were not attracted by VOCs traps in unburnt habitats and the control traps in both habitats. These insects were not found by hand collection. However, it cannot be ruled out that these species had been overlooked.

Eight hand- caught insect species in our study (Fig. 3) showed pyrophilous behavior because they approached the freshly burnt habitat. However, they were not caught by our VOC traps. Prior studies (Schütz et al., 1999; Morimoto et al., 2006; Paczkowski et al., 2013, 2014; Geiser 2016) reported the perception of burnt wood volatiles by pyrophilous insects (cf. Tab. 1). VOCs in Tab. 1 were released consistently also by Vietnamese woody species upon heating. These data demonstrate that the preference for burnt wood volatiles obviously differs within pyrophilous insect species.

Table 1: Perception of burnt wood volatiles by pyrophilous insects according to the literature.

\begin{tabular}{|l|c|c|c|c|}
\hline \multicolumn{1}{|c|}{ Compound } & $\begin{array}{c}\text { Melanophila } \\
\text { acuminata }\end{array}$ & $\begin{array}{c}\text { Melanophila } \\
\text { cuspidata }\end{array}$ & $\begin{array}{c}\text { Merimna } \\
\text { atrata }\end{array}$ & $\begin{array}{c}\text { Acanthocnemus } \\
\text { nigricans }\end{array}$ \\
\hline Hydroxyacetone & & $\begin{array}{c}\text { Paczkowski et } \\
\text { al., 2013 }\end{array}$ & $\begin{array}{c}\text { Paczkowski et al., } \\
2014\end{array}$ \\
\hline Furfural & $\begin{array}{c}\text { Paczkowski et } \\
\text { al., 2013 }\end{array}$ & $\begin{array}{c}\text { Paczkowski } \\
\text { et al., 2013 }\end{array}$ & \\
\hline 2-Furanmethanol & & $\begin{array}{c}\text { Paczkowski et } \\
\text { al., 2013 }\end{array}$ & $\begin{array}{c}\text { Paczkowski } \\
\text { et al., 2013 }\end{array}$ & \\
\hline 5-methylfurfural & & $\begin{array}{c}\text { Paczkowski et } \\
\text { al., 2013 }\end{array}$ & $\begin{array}{c}\text { Paczkowski } \\
\text { et al., 2013 }\end{array}$ & $\begin{array}{c}\text { Paczkowski et al., } \\
2014\end{array}$ \\
\hline
\end{tabular}




\begin{tabular}{|l|c|c|c|c|}
\hline Guaiacol & $\begin{array}{c}\text { Schütz et } \\
\text { al.,1999 }\end{array}$ & $\begin{array}{c}\text { Paczkowski et } \\
\text { al., 2013 }\end{array}$ & $\begin{array}{c}\text { Paczkowski } \\
\text { et al., 2013 }\end{array}$ & $\begin{array}{c}\text { Paczkowski et al., } \\
2013\end{array}$ \\
\hline 4-Methylguaiacol & & $\begin{array}{c}\text { Paczkowski et } \\
\text { al., 2013 }\end{array}$ & & $\begin{array}{c}\text { Paczkowski et al., } \\
2014\end{array}$ \\
\hline 4-Ethyl-guaiacol & & & $\begin{array}{c}\text { Paczkowski } \\
\text { et al., 2013 }\end{array}$ & $\begin{array}{c}\text { Paczkowski et al., } \\
2014\end{array}$ \\
\hline
\end{tabular}

\subsubsection{Links between burnt wood volatiles and the biodiversity of pyrophilous insects}

Our results show that there is a diversity of VOCs released upon heating wood and also a diversity of pyrophilous insects caught by VOC-baited traps and by hand collection. Prior studies (Schütz et al., 1999; Morimoto et al., 2006; Paczkowski et al., 2013, 2014; Geiser 2016) reported the perception of burnt wood volatiles by pyrophilous insects (Tab. 1). Data so far available show that guaiacol is perceived by all pyrophilous insects (Tab. 1) and the compound 5-methylfurfural is perceived by most pyrophilous beetles (Tab. 1). Our data suggest that guaiacol and 5-methylguaiacol are general fire VOCs which attract the pyrophilous insect species caught in our VOC traps. Because guaiacols are general indicators for the combustion of lignin, results indicate that the captured species belong to the group of general pyrophilous insects.

In contrast, eight insect species were caught close to smoldering logs but not by VOC traps. A possible explanation may be that these Vietnamese species are not attracted by the VOCs presented in the traps but by other fire-specific volatiles. These hitherto unknown compounds could, therefore, function as a fire-specific marker for specialized insects and govern host tree selection. This suggests the selective use of a general array of thermal degradation products from different plant species by a variety of pyrophilous insects, which demonstrates a link between the chemo-diversity of plant combustion products and the biodiversity of pyrophilous insects.

It would be also possible that insects found on freshly burnt habitats were not attracted by firespecific VOCs. These non-pyrophilous insects might have been attracted by fire-weakened trees. Theoretically, this group of insects could perceive different volatiles emitted by dead wood or by dying trees suffering from water deficiency. Another group of potentially pyrophilous insects may use different cues to approach fires, for example, infrared radiation (Wikars 1992; Schütz et al., 1999; Schmitz et al., 2008, 2010).

\subsection{Conclusion}

In conclusion, the differences in the VOCs released by the thermal degradation of lignin and polysaccharides upon heating suggest that they are related to the properties of a certain plant 
species. For example, these include wood properties such as a high extractive content and heartwood composition, or ecological traits such as a high defence status or special microhabitats, as exemplified by bamboo. Such functional biodiversity of plant species seems to be associated with the chemo-diversity of fire-induced VOCs. This might play an essential role in host plant selection and link plant diversity to the diversity of pyrophilous insects.

Several common VOCs, such as guaiacol and 5-methylfurfural, were released by all of the woody plant species tested in the temperature interval of $250^{\circ} \mathrm{C}$ and $300^{\circ} \mathrm{C}$ and might serve as candidate marker compounds for generalist pyrophilous insects. However, more specialized pyrophilous insects may also use these VOCs to detect a fire.

Several special VOCs and temperature-independent VOCs were also identified, allowing for the frequent and reliable separation of all of the tested plant species and serving as candidate marker compounds for specialized pyrophilous insects.

The field test revealed generalized pyrophilous insects a well as potentially specialized pyrophilous insects that may be attracted by the mentioned groups of VOCs. It can be suggested that these compounds mediate the diversity of insect assemblies and link plant biodiversity to the chemo-diversity of fire-induced VOCs and consequently to the biodiversity of pyrophilous insects at the biodiversity hotspot of the Central Highlands of Vietnam.

Our study, however, focused on the biodiversity of Vietnamese pyrophilous insects by testing a mixture of burnt wood volatiles. Future studies should, therefore, focus on the biodiversity of pyrophilous insects, which respond to different fire-relevant stimuli, for example, dealing with a broader spectrum of volatiles and infrared radiation. In this way the specific ecological niches of pyrophilous insect species on burnt areas can be described, including knowledge about the plants that have to be damaged by the fire.

\subsection{Acknowledgments}

TPH was supported by the Catholic Academic Exchange Service (KAAD - Katholischer Akademischer Ausländer-Dienst), Germany. Technical support from Ulrike Eisenwiener and Sara Nicke is gratefully acknowledged. Administrative support during sample collection in the Vietnam Central Highlands by the provincial Forest Protection Department of Kon Tum is also gratefully acknowledged. 


\subsection{References}

Azeez, A. M., Meier, D., Odermatt, J. and Willner, T. (2010). Fast pyrolysis of African and European lignocellulosic biomasses using Py-GC/MS and fluidized bed reactor. Energy \& Fuels, 24(3): 2078-2085.

Branca, C., Di Blasi, C. and Elefante, R. (2006). Devolatilization of conventional pyrolysis oils generated from biomass and cellulose. Energy Fuels, 20(5): 2253-2261.

De Simon, B. F., Esteruelas, E., Muñoz, A. M., Cadahía, W. and Sanz, M. (2009). Volatile compounds in acacia, chestnut, cherry, ash, and oak woods, with a view to their use in Cooperage. Journal of Agricultural and Food Chemistry, 57(8): 3217-3227.

Del Río, J. C., Gutiérrez, A., Romero, J., Martínez, M. J. and Martínez, A.T. (2001). Identification of residual lignin markers in eucalypt kraft pulps by Py-GC/MS. Journal of Analytical and Applied Pyrolysis, 58-59: 425-439.

Evans, W. G. (1966). Perception of infrared radiation from forest fires by Melanophila acuminata De Geer (Buprestidae, Coleoptera). Ecology 47(6): 1061-1065.

Flematti, G. R., Ghisalberti, E. L., Dixon, K. W. and Trengove, R. D. (2004). A compound from smoke that promotes seed germination. Science, 305(5686): 977.

Geiser, M. (2016). An update on the distribution of the pyrophilous beetle Acanthocnemus nigricans (Hope, 1845) (Coleoptera: Cleroidea: Acanthocnemidae), including new records from Laos. Entomologica Basiliensia et Collectionis Frey, 35: 429-432.

Guillen, M. D., Sopelana, P., and Partearroyo, M. A. (2000). Polycyclic aromatic hydrocarbons in liquid smoke flavorings obtained from different types of wood. Effect of storage in polyethylene flasks on their concentrations. Journal of Agricultural and Food Chemistry, 48(10): 5083-5087.

Hoang, T. P. and Schütz, S. (2015). Pyrophilous insects in Vietnam central highlands. Mitteilungen Deutsche Gesellschaft für allgemeine und angewandte Entomologie, 20: 133138.

Kollmann, F. (1982). Technologie des Holzes und der Holzwerkstoffe, Anatomie und Pathologie, Chemie, Physik, Elastizität und Festigkeit. Springer, Berlin, Germany, 1051 pp.

Le, S. (1996). Vietnam forest trees. Agricultural Publishing House.

Le, T. H., Thanh Nguyen, T. N., Lasko, K., Ilavajhala, S., Vadrevu, K. P. and Justice, C. (2014). Vegetation fires and air pollution in Vietnam. Environmental Pollution, 195: 267-275.

Lourenço, A., Neiva, D., Gominho, J., Marques, A. V. and Pereira, H. (2015). Characterization of lignin in heartwood, sapwood and bark from Tectona grandis using PyGC-MS/FID. Wood Science and Technology, 49(1): 159-175.

Maleknia, S. D., Bell, T. L., and Adams, M. A. (2009). Erratum to "Eucalypt smoke and wildfires: Temperature dependent emissions of biogenic volatile organic compounds". International Journal of Mass Spectrometry, 279(2-3): 126-133. 
McNamara, S., Tinh, D. V., Erskine, P. D., Lamb, D., Yates, D., \& Brown, S. (2006). Rehabilitating degraded forest land in central Vietnam with mixed native species plantings. Forest Ecology and Management, 233(2-3): 358-365.

Mehmetli, E., Dogan, Ö., Tiris, M., Kiran, N. C. and Matuschek, G. (2008). Thermolysis product distribution of solid waste obtained from olive oil production. CLEAN - Soil, Air, Water, 36(3): 315-319.

Morimoto, M., Fukumoto, H., Hiratani, M., Chavasiri, W. and Komai, K. (2006). Insect antifeedants, pterocarpans and pterocarpol, in heartwood of Pterocarpus macrocarpus Kruz. Bioscience, Biotechnology, and Biochemistry, 70(8): 1864-1868.

Noudogbessi, J.-P., Yédomonhan, P., Sohounhloué, D., C., K., Chalchat J.-C. and Figuérédo, G. (2008). Chemical composition of essential oil of Syzygium guineense (Willd.) DC. var. guineense (Myrtaceae) from Benin. Records of Natural Products, 2(2): 33-38.

Paczkowski, S. (2013). Insect olfaction as an information filter for chemo-analytical applications. PhD Thesis. Faculty of Forest Sciences and Forest Ecology. University of Göttingen, Germany.

Paczkowski, S., Paczkowska, M., Dippel, S., Schulze, N., Schütz, S., Sauerwald, T., et al. (2013). The olfaction of a fire beetle leads to new concepts for early fire warning systems. Sensors and Actuators, B: Chemical, 183: 273-282.

Paczkowski, S., Paczkowska, M., Dippel, S., Flematti, G. and Schütz, S. (2014). Volatile combustion products of wood attract Acanthocnemus nigricans (Coleoptera: Acanthocnemidae). Journal of Insect Behaviour, 27: 228-238.

Piskorz, J., Radlein, D. and Scott, D. S. (1986). On the mechanism of the rapid pyrolysis of cellulose. Journal of Analytical and Applied Pyrolysis, 9(2): 121-137.

Schmitz, A., Gebhardt, M. and Schmitz, H. (2008). Microfluidic photomechanic infrared receptors in a pyrophilous flat bug. Naturwissenschaften, 95(5): 455-60.

Schmitz, A., Schätzel, H. and Schmitz, H. (2010). Distribution and functional morphology of photomechanic infrared sensilla in flat bugs of the genus Aradus (Heteroptera, Aradidae). Arthropod Structure \& Development, 39(1): 17-25.

Schütz, S., Weißbecker, B., Hummel, H. E., Apel, K.-H., Schmitz, H. and Bleckmann, H. (1999). Insect antenna as a smoke detector. Nature, 398: 298-299.

Wikars, L.O. (1992). Skogsbränder och insekter. Entomologisk Tidskrift, 133(4): 1-11.

Wikars, L.O. (1997). Effects of forest fire and the ecology of fire-adapted insects. Comprehensive Summaries of Uppsala Dissertations from the Faculty of Science and Technology 272. Acta Universitatis Upsaliensis, Uppsala, Sweden, 272 pp. 


\section{Chapter 4}

\section{Pyrophilous insects respond to different stimuli}

This is a manuscript prepared for submission. I conducted all experiments and prepared the manuscript. 


\begin{abstract}
Pyrophilous insects are attracted by fires, taking advantage from developing a part of their life cycle in freshly burnt habitats. They developed efficient senses for such an environment, responding to smoke and heat by using special receptors such as infrared (IR) organs and smoke-sensitive olfactory receptors on antennal sensilla. To disentangle how such sensory modalities contribute to behavior, we examined the reactions of insects in a freshly burnt habitat to traps equipped with IR stimuli or fire-specific volatile organic compounds (VOCs) or a combination of both in comparison to a control trap. Major fire-specific VOCs are thermal degradation products of cellulose, such as 5-methylfurfural, hydroxyacetone, and lignin (guaiacol, 4-ethyl-guaiacol). The primary aim of our study was that a newly developed IR trap attracts pyrophilous insects and to compare efficiency and species composition of insects caught by fire-specific VOCs and IR stimuli.

A total of 26 insect species were recorded. The attraction of pyrophilous insects towards firespecific VOCs, IR and combined stimuli was significantly higher compared to the controls. Only one species (Litochrus sp. 1, Phalacridae, Coleoptera) was found in all three trap types. Insects considered to be fungivorous were caught significantly more often in the IR trap, whereas VOC traps attracted more carnivorous insects. All traps attracted a number of herbivorous insects.

Eight species were caught in more than one trap type. Two predatory beetles of the family Cleridae were caught in either IR trap or the IR combination with VOC mixture. These results hint at a complex evaluation of IR and olfactory stimuli for resource location by different members of the pyrophilous insect community.
\end{abstract}

Keywords: Pyrophilous insects, forest fires, infrared radiation, fire-specific volatiles, trapping methods. 


\subsection{Introduction}

Pyrophilous insects depend on forest fires to varying degrees. Some xylophagous species among them approach forest fires for mating and oviposition, because their larvae can only develop in the wood of freshly burnt trees (Linsley 1943; Apel 1988). The well-known pyrophilous jewel beetles of the genus Melanophila (Buprestidae) are not only equipped with one pair of metathoracic infrared (IR) organs (Evans 1964; Vondran et al., 1995; Schmitz et al., 1997), but also with special antennal olfactory “smoke” receptors (Schütz et al., 1999). Earlier investigations showed that such specialized pyrophilous insects are attracted to volatile organic compounds released by thermal degradation of wood (Paczkowski et al., 2013, 2014). Other studies focus on the IR receptors (Schmitz et al., 2002; Kreiss et al., 2005, 2007; Schmitz et al., 2008, 2010). While all insects have olfactory senses, few pyrophilous insect species have evolved IR receptors independently and could detect fires using both VOC cues and IR cues. For example, Acanthocnemus nigricans (Cleroidea) uses a specialized IR sensory organ to detect the IR radiation emitted by hot surfaces (Schmitz et al., 2002; Kreiss et al., 2005, 2007). On the other hand, little attention was paid on the behavioral responses of pyrophilous insects towards IR radiation, or mixtures of fire-specific volatiles or combinations of both. Pyrophilous insects are often characterized by their occurrence in fire situations or the presence of morphological features such as IR receptors. However, no traps are available that imitate a fire by releasing fire-specific volatiles and/or IR radiation to attract insects with a pyrophilous lifestyle.

The aim of the present work was to develop a trap including a source of IR radiation to test whether we can attract particularly the pyrophilous insect species in the field. With the newly designed traps we tested and compared the attractiveness of IR radiation but also fire-specific volatiles, and the combination of both. For an explorative field study and a proof of principle we therefore constructed two traps capable of emitting IR radiation. Two traps of the same design released only a mixture of VOCs (VOC trap), a trap emitting IR radiation (IR trap), the other released additionally a fire-specific VOCs mixture (IRVOC trap), and two empty control traps of the same design. The chosen fire-specific volatiles included hydroxyacetone and 5methylfurfural, as these are characteristic products of the thermal degradation of cellulose (Piskorz et al., 1986; Flematti et al., 2004), guaiacol and 4-ethylguaiacol. These compounds are typical products of the thermal degradation of lignin (Branca et al., 2006, Azeez et al., 2010). The study has been conducted in Vietnam, where forest fires are abundant and occur often over a long season (Hoang \& Schütz 2015). While the contribution of IR and/or fire-specific VOCs to the attraction of pyrophilous insects has generally not been studied in detail, systematic 
investigations of freshly burnt areas to characterize pyrophilous insects of Vietnam have not been carried out so far.

\subsection{Material and methods}

\subsubsection{Trap construction}

All traps used in this study were designed as X-pane flight interception traps made from two perpendicular panes of $40 \mathrm{~cm}$ width and $60 \mathrm{~cm}$ height, and were suspended at $1 \mathrm{~m}$ height above ground. Flight interception traps (type "Witaprall Ecco", Witasek, Feldkirchen, Germany), made of black plastic boards, a black funnel, and a collection container were used as control trap and trap baited with VOCs (VOC traps). The IR traps were also designed as X-pane flight interception traps made from two perpendicular metal panes to resist the IR emitter heat. Panes were as well of $40 \mathrm{~cm}$ width and $60 \mathrm{~cm}$ height. The panels serve as reflectors for the IR emitter that extend from the upper end of the container to the upper end of the head plate (Fig. 1). The head plate has a hook which is used for the installation of the trap. Infrared traps comprised of four IR emitters. These 125-Watt IR emitters have a size of $60 \times 60 \mathrm{~mm}$. These IR emitters are fastened by bolts to the vertical support. The insects fall through a funnel into the trapping container, which has a throat and a plastic bottle (Vitlab, PFA $1000 \mathrm{ml}$ ) as a reservoir portion (Fig. 1). VOC traps and IR-VOC traps were provided with $8.2 \mathrm{ml}$ VOCs mixture $(2 \mathrm{ml}$ hydroxyacetone, $2 \mathrm{ml}$ guaiacol, $2 \mathrm{ml} 5$-methylfurfural and $0.2 \mathrm{ml}$ 4-ethyl-guaiacol) in a $10 \mathrm{ml}$ glass vial with an opening of $1 \mathrm{~cm}^{2}$ in the center at the lower end of the panes. 


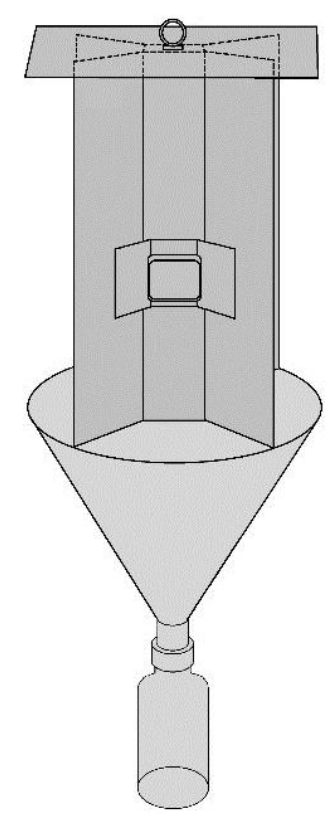

Figure 1: Infrared trap with four IR emitters to each direction at the middle of the metal reflectors.

\subsubsection{Estimation of the trapping radius of the trap emitting IR radiation}

We use a modified Stefan-Boltzmann formula according to Ebert \& Westhoff (2006) to estimate the active trapping radius of the IR traps:

$$
\operatorname{Irradiance} \text { contrast }\left(\mathrm{W} / \mathrm{cm}^{2}\right)=\frac{\sigma A\left(T_{2}^{4}-T_{1}^{4}\right)}{\pi D^{2}}
$$

where $\sigma$ is the Stefan-Boltzmann constant $\left[5.6522 \cdot 10^{-12} \mathrm{~W} /\left(\mathrm{cm}^{2} \mathrm{~K}^{4}\right)\right]$; A the radiating area $\left(6^{*} 6 \mathrm{~cm}^{2}\right)$; T2, temperature $\left({ }^{\circ} \mathrm{K}\right)$ of IR emitters $\left(486^{\circ} \mathrm{C}=759^{\circ} \mathrm{K}\right)$; $\mathrm{T} 1$, temperature $\left({ }^{\circ} \mathrm{K}\right)$ of the panes $\left(35^{\circ} \mathrm{C}=308.15^{\circ} \mathrm{K}\right)$. Thus, the temperature difference between the IR source and the panes $(\mathrm{T} 2$ - T1) as well as the radiating area (A) of the IR source determines the trapping radius distance (D) (Ebert \& Westhoff 2006). If a sensitivity of an insect IR receptor of $60-100$ $\mu \mathrm{W} / \mathrm{m}^{2}$ is assumed (corresponding to the reported sensitivity of the thoracic IR organs of Melanophila beetles, Evans 1966) the trapping radius of our IR traps was $5 \mathrm{~m}$ (IR radiation intensity $83 \mu \mathrm{W} / \mathrm{cm}^{2}$ ). However, in a theoretical simulation study a much higher sensitivity of the Melanophila IR sensilla of $1.3 \mathrm{nW} / \mathrm{cm}^{2}$ has been postulated (Schmitz \& Bousack 2012). In this theoretical case a trapping radius of more than $1 \mathrm{~km}$ would result (IR radiation intensity at a distance of $\left.1 \mathrm{~km}: 2 \mathrm{nW} / \mathrm{cm}^{2}\right)$. 


\subsubsection{Estimation of the trapping radius of the trap baited VOCs}

To estimate the active trapping radius of a VOC trap, emission rates of guaiacol from the vial ( $2 \mathrm{ml} /$ day) were used to calculate a distance-dependent dilution factor at given wind velocities (Bossert et al., 1963). We compared this factor to the detection limit of Melanophila acuminata (Schütz et al., 1999) at $10 \mathrm{ng} / \mathrm{ml}$ (of $10 \mathrm{ng} / \mathrm{cm}^{3}$ ). Assuming a wind speed of $30 \mathrm{~cm}$ per second, the active trapping radius of the VOC trap would be around $50 \mathrm{~m}$.

\subsubsection{Chemicals}

Hydroxyacetone was obtained from Aldrich Co. (St. Louis, Missouri, USA), 5-methylfurfural from Acros Co. (Belgium, Wisconsin, USA), guaiacol from Fluka (Buchs, Switzerland) and 4ethylguaiacol from SAFC Co. (St. Louis, Missouri, USA). Compounds (> 97\% purity) were of analytical quality.

\subsubsection{Study area and experimental design}

The experiments were carried out in forested areas in Ngoc Reo Forest, inside pine (Pinus sp.) plantations, adjacent to the secondary forest of Chu Mom Ray National Park and inside the national park (Sa Thay district, Kon Tum province, Vietnam Central Highlands). Mean (day and night) temperature (2015) at the study area was $22.2^{\circ} \mathrm{C}$ during the sample period (from February to April). Field research was conducted during the dry season from 16 February to 10 April 2015, when forests are usually burnt, and frequent fires took place in the research area. Traps were set up in two different types of habitats, including unburnt and freshly burnt areas (from 1 -10 days after the fire). The unburnt habitat was selected to provide an undisturbed reference of control samples, whereas freshly burnt habitats were chosen for investigating the presence of pyrophilous insects. The trap setup was installed in a block design, with three blocks arranged in a north-south line alongside wind direction. The designed block had an open canopy in the center of at least $300 \mathrm{~m} \times 400 \mathrm{~m}$ to allow space for a core circle with traps (Fig. 2). With the wind direction from north-south, the first VOC trap was placed in the furthest southeast, $100 \mathrm{~m}$ away from the square edge. The second VOC trap was installed in the furthest southwest, likewise. The IR trap with VOCs (IRVOC trap) was set up $100 \mathrm{~m}$ away from the first VOC trap in the northeast, whereas the IR trap was placed in parallel with the IRVOC trap and was installed $100 \mathrm{~m}$ away from the second VOC trap in the northwest. Two control traps were set up in the furthest northeast and northwest respectively. All traps were suspended $1 \mathrm{~m}$ above ground and applied to both habitat types. Each trap was active for 15 hours per day from 6:00 to 22:00 hours over 10 days. After each day, the VOC mixture was renewed. Every second day, 
the traps were placed on a new site. Insects were collected every three hours and kept in plastic boxes. Trap catches were sorted to morphologically similar groups and killed with ethyl-acetate before being labeled and stored in 50\% ethanol. Specimens collected from traps were sent to the Department of Insect Systematics at the Institute of Ecology and Biological Resources (IEBR) in Hanoi, Vietnam, for identification.

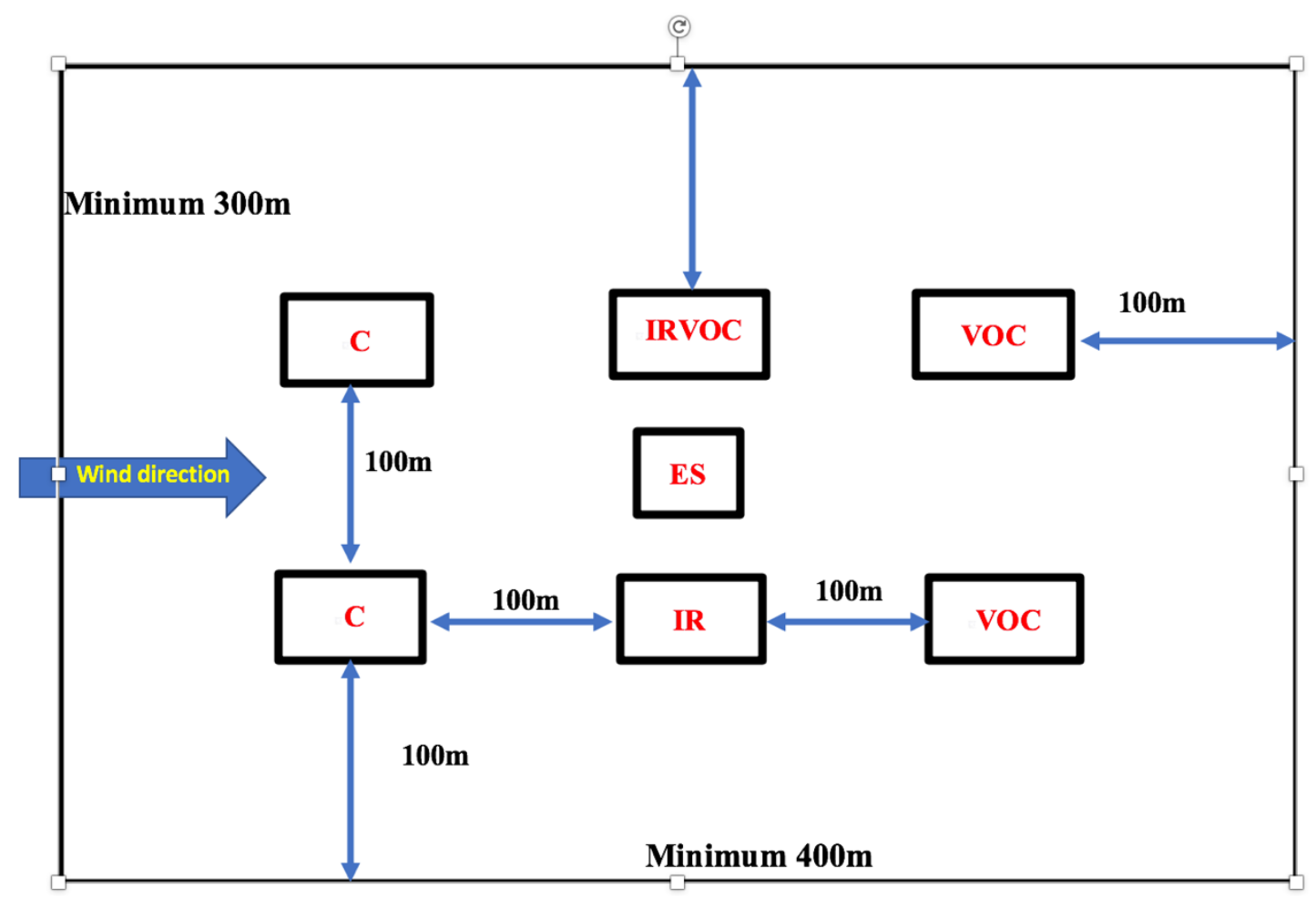

Figure 2: Symmetric drawing of the study design in Vietnam Central Highlands in 2015. C: Empty control traps. IR: traps emitting IR radiation. IRVOC: traps emitting IR radiation and containing a mixture of fire-specific volatile organic compounds. VOC: traps baited with a mixture of fire-specific volatile organic compounds. ES: electric supplier.

\subsubsection{Statistical tests}

Because the total insect species caught by each trap type in freshly burnt areas were smaller than $20(n<20)$, Wilcoxon rank-sum test was used to test for significant differences in the distribution of insect species between all traps, and significant differences between insect taxa caught in each trap. The significance level (P) was set at $95 \%$.

\subsection{Results}

A total of 1,246 insects belonging to 26 species were caught on the freshly burnt areas. Of these, 338 beetles $(27 \%)$ belonging to nine species were found in IR traps and 270 beetles $(22 \%)$ of 14 species in VOC traps. The VOC1 and VOC2 traps yielded 226 insects (18\%) in total, belonging to 14 species, while the trap combining IR with volatiles (IRVOC) yielded 412 
individuals (33\%) of 12 species. The abundance of insects caught by the three trap types (VOC1, VOC2, IR, and IRVOC) showed statistically significant differences with the beetles caught by the control traps $(\mathrm{P}=0.000053,0.000053,0.000053$ and 0.000053 respectively) (Fig. 3). The number of species caught in the IRVOC trap was significantly different from the volatile traps ( $\mathrm{P}=0.0028$ and 0.0019 respectively) (Fig. 3). There were no significant differences in the number of insects species caught by both VOC traps (VOC1 and VOC2). None of the insect species recorded by the other trap types was found in control traps. Equally, control traps in burnt habitats yielded other insect species which were not found in other traps such as: Salganea sp. (Blattodea, Blattidae), Catapiestus sp. (Coleoptera, Tenebrionidae), Xylocopa confusa (Perez, 1901) (Hymenoptera, Apidae). A different insect species composition was recorded in these traps in unburnt habitat when compared to burnt habitat. The species included Demonax bowringii (Pascoe, 1859) (Coleoptera, Cerambycidae), Chlorophorus quatourdecimmaculatus (Chevrolat, 1863) (Coleoptera, Cerambycidae), Laius sp. (Coleoptera, Melyridae), Anomala russiventris (Fairmaire, 1893) (Coleoptera, Scarabaeidae), Anomala sp (Coleoptera, Scarabaeidae), Apis cerana (Fabricius, 1793) (Hymenoptera, Apidae) and Syzeuctus sp. (Hymenoptera, Ichneumonidae). 

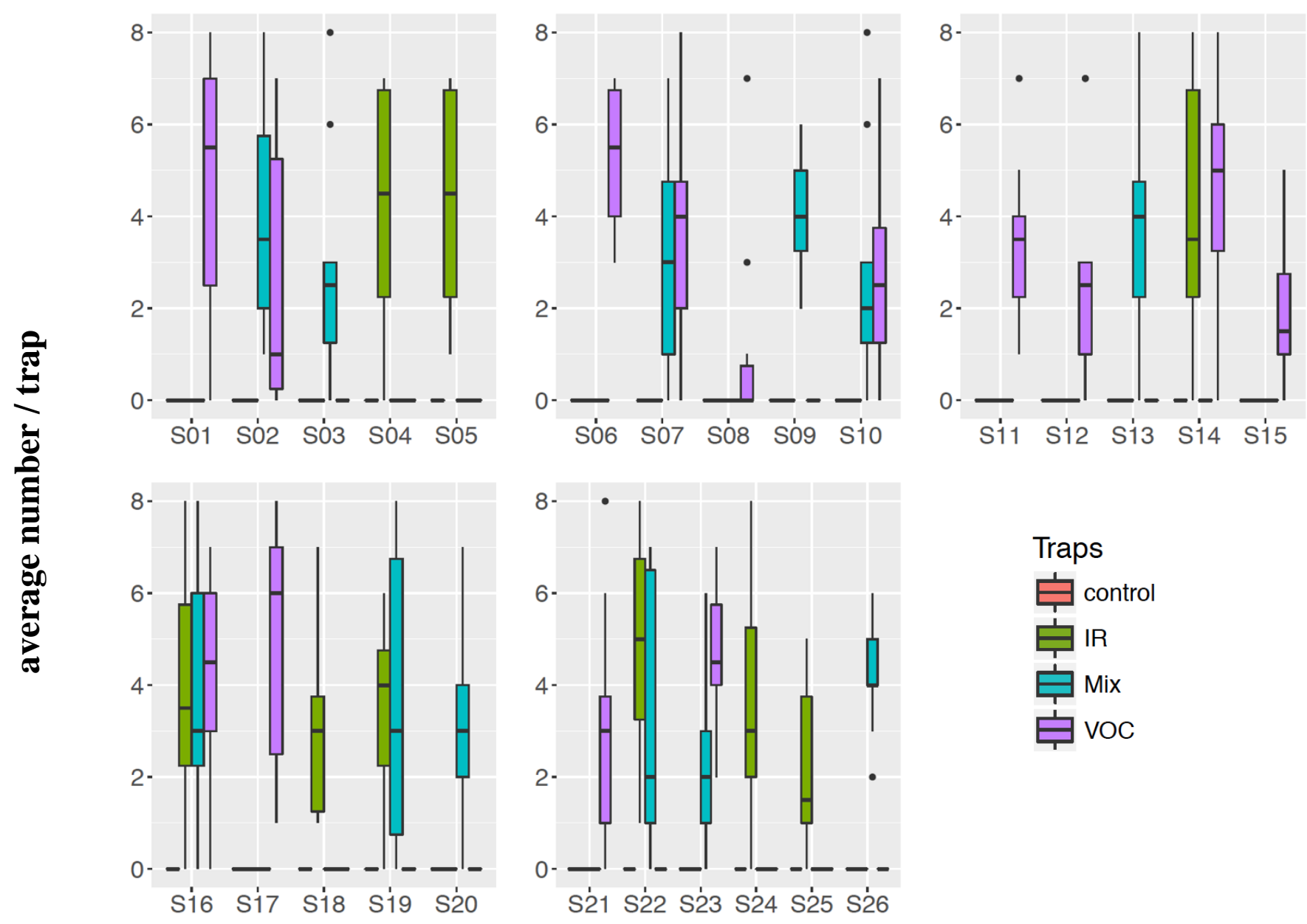

Insect species

Figure 3: Mean numbers of beetles captured on freshly burnt areas. Bars and whiskers display the median, upper and lower quartiles and maxima and minima. The sum shows the overall number of pyrophilous insects caught in each trap type. None of these insect species were caught by these trap types on unburnt areas and in habitats burnt one year ago. No species of insect listed in the figure was caught by control traps. VOC = trap baited with a mixture of VOCs; IR = trap emitting IR radiation; IRVOC $(\mathrm{Mix})=$ combined trap releasing VOCs and emitting IR radiation.

S01-S26: Insect species 1 to 26, all belonging to Coleoptera; S01-S08: Carnivorous insect species; S01: Apristus sp. 1 (Carabidae), S02: Anthicoclerus sp. 1 (Cleridae), S03: Anthicoclerus sp. 1 (Cleridae), S04: Nephus boninensis (Coccinellidae), S05: Pseudoplectus sp. 1 (Pselaphidae), S06: Eleusis humilis (Staphylinidae), S07: Staphylinus sp. 2 (Staphylinidae), S08: Staphylinus sp. 3 (Staphylinidae).

S09-S20: Herbivorous insect species; S09: Colobicus sp. 1 (Colydiidae), S10: Cryphalus sp. 1 (Scolytidae), S11: Cryphalus sp. 2 (Scolytidae), S12: Wallacellus denticulus (Scolytidae), S13: Scolytus g. sp. 1 (Scolytidae), S14: Anacypta sp. 1 (Trogossitidae), S15: Anthicus sp. 1 (Anthicidae), S16: Litochrus sp. 1 (Phalacridae), S17: Perissus rayus (Cerambycidae), S18: Cryptolestes ferrugineus (Cucujidae): Monomma sp. 1 (Monommidae), S20: Elacatis sp. 1 (Salpingidae).

S21-S26: Fungivorous insect species; S21: Cartodere sp. 1 (Lathridiidae), S22: Cortinicara gibbosa (Lathridiidae), S23: Litargus sp. 1 (Mycetophagidae), S24: Psammoecus sp. 1 (Silvanidae), S25: Cathartus sp. 1 (Silvanidae), S26: Silvanus bidentatus (Silvanidae).

Overall more species were caught in traps releasing VOCs alone (13) than in traps emitting only IR or in combination with VOCs (8). Surprisingly, only five species were attracted by IRVOC traps but not by other trap types (Fig. 3) 
Regarding feeding guilds, the overall number of carnivorous insect species caught by VOC1 and VOC2 traps was significantly lower than that caught by IRVOC traps $(\mathrm{P}=0.0043$ and 0.00017 ; VOC1 and VOC2 respectively). Numbers of herbivorous insect species caught by VOC, IR and IRVOCs were not statistically different from each other in a pairwise comparison. The numbers of fungivorous insect species in IR traps significantly differed from VOC1, VOC2 and IRVOC traps $(\mathrm{P}=0.007,0.0048$ and 0.00037 respectively). The number of fungivorous insect species in the VOC1 and VOC2 traps was significantly higher in comparison with those in IRVOC traps $(\mathrm{P}=0.0015$ and 0.0016 respectively) (Fig. 4).

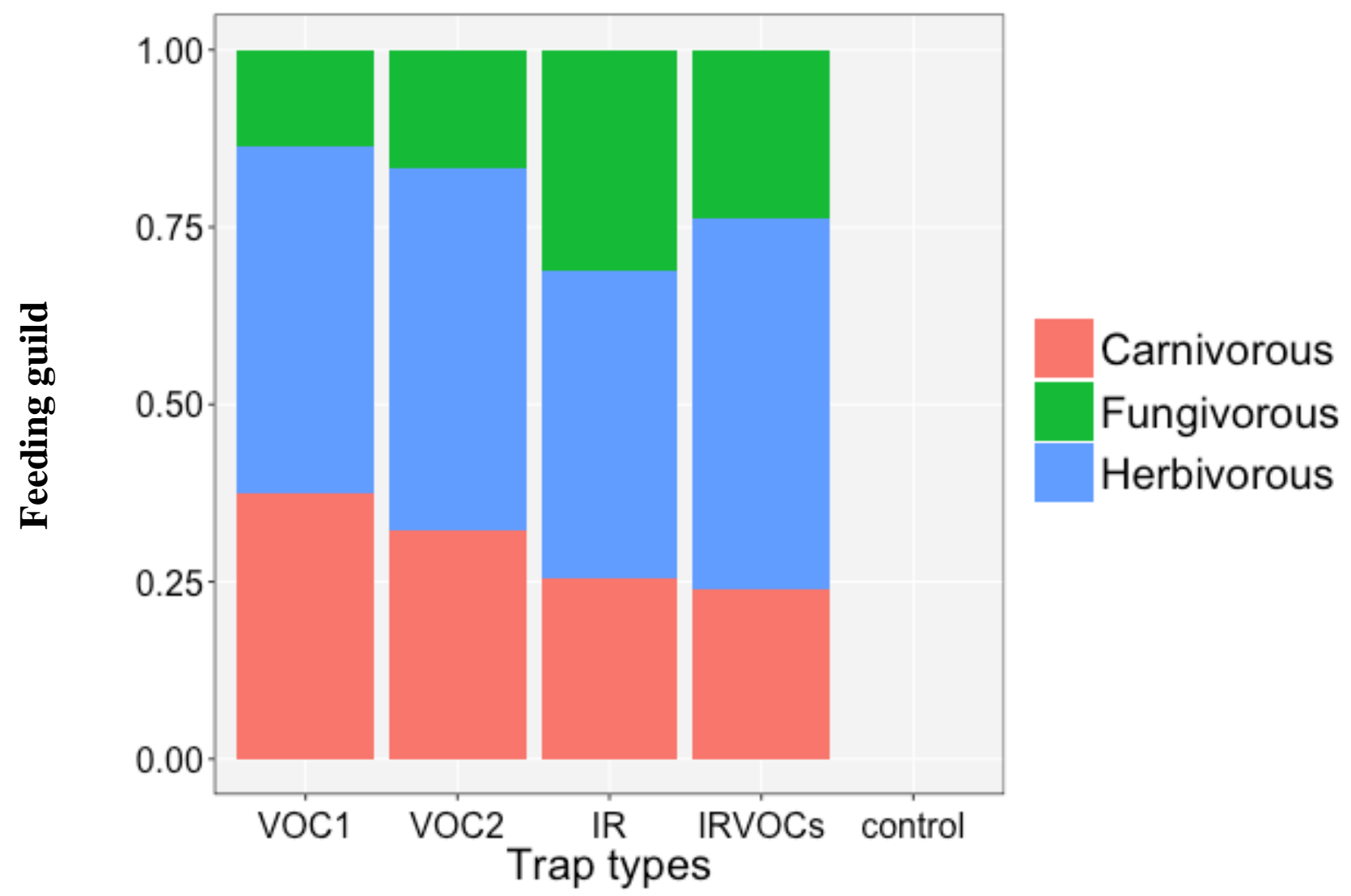

Figure 4: Mean number of insects caught by traps releasing different types of fire-specific cues. Insects were grouped together as feeding guilds (carnivorous, fungivorous and herbivorous) according to literature knowledge. VOC $=$ trap baited with the mixture of VOCs; IR = trap emitting IR radiation; IRVOCs = combined traps releasing VOCs and IR radiation.

\subsection{Discussion}

The main aim of our study was to test the attractiveness for pyrophilous insects of a newly constructed trap emitting major fire-specific cues such as IR radiation and fire-specific volatiles. In comperison to control traps, our numerous trap catches from recently burnt habitats demonstrate that our newly developed trap emitting either IR radiation, fire-specific VOCs or a combination of both effectively attracted insects likely having a pyrophilous lifestyle. In 
detail, differences in their attraction according to different fire-relevant stimuli tested became apparent suggesting that IR radiation alone might be capable of attracting pyrophilous insects, while fire-specific VOCs or their combination with IR radiation seemed to play a major role for their attraction in recently burnt forests. Similarly, the number of species occuring in VOC traps alone exceeded the number of those found in IR traps only. Due to a very limited number of custom-made traps capable of emitting IR radiation, results should be interpreted cautiously. Results, however might indicate that certain species of pyrophilous insects rely either on IR or on VOC stimuli, but are not susceptible to both stimuli, while the majority combines both informations. There is also no clear tendency that IR radiation increases or decreases the attractivity of VOCs alone.

The attraction of pyrophilous insects to traps emitting IR radiation might be expected because a few species of pyrophilous beetles possess IR receptors (Schmitz et al., 2002; Kreiss et al., 2005, 2007; Paczkowski et al., 2014) to detect hot surfaces, for example, A. nigricans, Merimna atrata, and Melanophila acuminata. Our study indicates that nine species of insects are attracted to pure IR traps. However, these beetles neither have been described as pyrophilous nor reported to have IR receptors in early studies. A search for IR receptors, therefore, may be rewarding.

The majority of the species was found in traps containing fire-specific volatiles. VOCs play an important role in host-finding in herbivorous insects (Bernays \& Chapman 1994), saproxylic and fungivorous insects (Holighaus 2012), or also in pyrophilous insects (Schütz et al., 1999). However, instead of truly smoke volatiles like 4-ethylguaiacol, guaiacol is also produced by deadwood or maybe by microorganisms (Holighaus 2006). Similarly, hydroxyacetone is found in the fermentation product of wood sap (Ômura et al., 2000), and 5-methylfurfural is a part of the containing fermentation/vinegar related compounds which was used to lure a nonpyrophilous fruit fly Drosophila melanogaster (Becher et al., 2010). Therefore, the insects attracted by such a single component are not necessarily pyrophilous. To increase fire specificity of VOC lures we used baits containing a mixture of fire-specific VOCs. It is, therefore, very important to confirm the responses of these insects by other additional examinations such as Electroantennography (EAG) experiments or a search for IR receptors. Surprisingly, only five insect species were caught only by IRVOC traps but not by the other traps. This disproves our expectation that the IRVOC trap would attract the same species found in the VOC and IR traps. The reason for this is not apparent. Further experiments are required to clarify this point.

Several fungivorous insect species (33\%) were attracted by our mixture of fire-specific VOCs. 
As expected, these saproxylic species (Cartodere sp. (Lathridiidae)) and Litargus sp. (Mycetophagidae) (Cocciufa et al., 2014) might be attracted to guaiacol because this compound is also produced by deadwood (Holighaus 2006). In contrast, $33 \%$ of other saproxylic species fungivorous insect species (Cortinicara gibbosa (Lathridiidae), Psammoecus sp. (Silvanidae) (Cocciufa et al., 2014) were attracted by the IR trap stronger than expected. A search for the IR receptors is recommended for further interpretation.

\subsection{Conclusion}

With the limited number of replicants and without further confirmation by EAG experiments and IR examination, we could not be able to conclude the attraction response of insects to a trap emitting IR radiation when positioned on freshly burned areas. However, with several numbers of insect species caught by the IR trap, the trap can, therefore, be used for further studies on the appearance and behavior of pyrophilous insects. Our study revealed the complexity in stimuli selection by different species of pyrophilous insects. The preference to certain stimuli or to all stimuli by an insect species and a search for IR receptors in several insect species attracted to IR traps would be a starting point for further studies.

\subsection{Acknowledgements}

TPH was supported by the Catholic Academic Exchange Service (KAAD - Katholischer Akademischer Ausländer-Dienst), Germany. Technical support from Andreas Teichmann, Ulrike Eisenwiener and Sara Nicke is gratefully acknowledged. Thanks to Daniel Jestrzemski for his help with establishing the figure. Administrative support during sample collection in the Vietnam Central Highlands by the provincial forest protection department of Kon Tum is also gratefully acknowledged. 


\subsection{References}

Apel, K.-H. (1988). Befallsverteilung von Melanophila acuminata Deg, Phaenops cyanea F und Ph. formaneki Jacob (Col., Buprestidae) auf Waldbrandflächen. Beiträge für die Forstwirtschaft, 22(2): 45-48.

Azeez, A. M., Meier, D., Odermatt, J. and Willner, T. (2010). Fast pyrolysis of African and European lignocellulosic biomasses using Py-GC/MS and fluidized bed reactor. Energy \& Fuels, 24(3): 2078-2085.

Becher, P. G., Bengtsson, M., Hansson, B. S. and Witzgall, P. (2010). Flying the fly: longrange flight behavior of Drosophila melanogaster to attractive odors. Journal of Chemical Ecology, 36(6): 599-607.

Bernays, E. A. and Chapman, R. F. (1994). Host-plant selection by phytophagous insects. Chapman \& Hall, New York, USA, 312 pp.

Bossert, W. H. \& Wilson, E. O. (1963). The analysis of olfactory communication among animals. Journal of Theoretical Biology, 5(3):443-469.

Branca, C., Di Blasi, C. and Elefante, R. (2006). Devolatilization of conventional pyrolysis oils generated from biomass and cellulose. Energy Fuels, 20(5): 2253-2261.

Cocciufa, C., Gerth, W., Luiselli, L., Redolfi De Zan, L., Pierfilippo Cerretti P. and Carpaneto, G.M. (2014). Survey of saproxylic beetle assemblages at different forest plots in central Italy. Bulletin of Insectology 67 (2): 295-306.

Ebert, J. and Westhoff, G. (2006). Behavioural examination of the infrared sensitivity of rattlesnakes (Crotalus atrox). Journal of Comparative Physiology, 192(9): 941-947.

Evans, G. (1964). Infra-red receptors in Melanophila acuminata DeGeer. Nature, 202: 211.

Evans, W. G. (1966). Perception of infrared radiation from forest fires by Melanophila acuminata De Geer (Buprestidae, Coleoptera). Ecology 47(6): 1061-1065.

Flematti, G. R., Ghisalberti, E. L., Dixon, K. W. and Trengove, R. D. (2004). A compound from smoke that promotes seed germination. Science, 305(5686): 977.

Hoang, T. P. and Schütz, S. (2015). Pyrophilous insects in Vietnam central highlands. Mitteilungen Deutsche Gesellschaft für allgemeine und angewandte Entomologie, 20: 133-138.

Holighaus, G. and Schütz, S. (2006). Odours of wood decay as semiochemicals for Trypodendron domesticum L. (Col., Scolytidae). Mitteilungen Deutsche Gesellschaft für allgemeine und angewandte Entomologie, 15: 161-165.

Holighaus, G. (2012). Odour signals relevant to beetles in deadwood habitats. PhD Thesis. Faculty of Forest Sciences and Forest Ecology. University of Göttingen, Germany.

Kreiss, E.-J., Schmitz, A. and Schmitz, H. (2005). Morphology of the prothoracic discs and associated sensilla of Acanthocnemus nigricans (Coleoptera, Acanthocnemidae). Arthropod Structure and Development, 34(4): 419-428. 
Kreiss, E., Schmitz, H. and Gebhardt, M. (2007). Electrophysiological characterisation of the infrared organ of the Australian "little ash beetle" Acanthocnemus nigricans (Coleoptera, Acanthocnemidae). Journal of Comparative Physiology, 193(7): 729-739.

Linsley, G. E. (1943). Attraction of Melanophila beetles by fire and smoke. Journal of Economic Entomology, 36(2): 341-342.

Ômura, H., Honda, K. and Hayashi, N. (2000). Identification of feeding attractants in oak sap for adults of two nymphalid butterflies, Kaniska canace and Vanessa indica. Physiological Entomology, 25(3): 281-287.

Paczkowski, S., Paczkowska, M., Dippel, S., Schulze, N., Schütz, S., Sauerwald, T., et al. (2013). The olfaction of a fire beetle leads to new concepts for early fire warning systems. Sensors and Actuators, B: Chemical, 183, 273-282.

Paczkowski, S., Paczkowska, M., Dippel, S., Flematti, G. and Schütz, S. (2014). Volatile combustion products of wood attract Acanthocnemus nigricans (Coleoptera: Acanthocnemidae). Journal of Insect Behaviour, 27: 228-238.

Piskorz, J., Radlein, D. and Scott, D. S. (1986). On the mechanism of the rapid pyrolysis of cellulose. Journal of Analytical and Applied Pyrolysis, 9(2): 121-137.

Schmitz, H., Bleckmann, H. and Mürtz, M. (1997). Infrared detection in a beetle. Nature, 386: 773-774.

Schmitz, H., Schmitz, A., Trenner, S. and Bleckmann, H. (2002). A new type of insect infrared organ of low thermal mass. Naturwissenschaften, 89: 226-229.

Schmitz, A., Gebhardt, M. and Schmitz, H. (2008). Microfluidic photomechanic infrared receptors in a pyrophilous flat bug. Naturwissenschaften, 95(5): 455-460.

Schmitz, A., Schätzel, H. and Schmitz, H. (2010). Distribution and functional morphology of photomechanic infrared sensilla in flat bugs of the genus Aradus (Heteroptera, Aradidae). Arthropod structure \& development 39(1): 17-25.

Schmitz, H. and Bousack, H. (2012). Modelling a historic oil-tank fire allows an estimation of the sensitivity of the infrared receptors in pyrophilous Melanophila beetles. PLoS One, 7(5): e37627. doi: 10.1371/journal.pone.0037627.

Schütz, S., Weißbecker, B., Klein, A. and Hummel, H. E. (1997). Host plant selection of the colorado potato beetle as influenced by damage induced volatiles of the potato plant. Naturwissenschaften, 84(5): 212-217.

Schütz, S, Weissbecker, B., Hummel, H. E., Apel, K.-H., Schmitz, H. and Bleckmann, H. (1999). Insect antenna as a smoke detector. Nature, 398(6725): 298-299.

Vondran, T., Apel, K. H. and Schmitz, H. (1995). The infrared receptor of Melanophila acuminata De Geer (Coleoptera: Buprestidae): ultrastructural study of a unique insect thermoreceptor and its possible descent from a hair mechanoreceptor. Tissue and Cell, 27(6): 645-658. 


\section{Chapter 5}

\section{Behavioral and sensory adaptations of the flat bug Aradus candidatus to post-fire habitats in Vietnam}

This is a manuscript prepared for submission. T. P. Hoang conducted all experiments and prepared the manuscript. Helmut Schmitz conducted the scanning electron microscope (SEM) part, contributed to the discussion and review of the manuscript. 


\begin{abstract}
The pyrophilous flat bug Aradus candidatus can be found in recently burnt habitats in Vietnam. Pyrophilous insects are known to approach these freshly burnt areas using fire-specific stimuli like the smell of smoldering logs and IR radiation. Recently, the response of pyrophilous insects to fire-specific volatile organic compunds (VOCs) has received increased scientific attention. Moreover, infrared (IR) receptors have been described in a few pyrophilous flat bug species of the genus Aradus. In our study, we investigated the responses of antennal olfactory receptors to fire-specific VOCs and the presence of infrared receptors in this species. The electroantennogram of the $A$. candidatus antenna clearly revealed its perception toward hydroxyacetone, 5-methylfurfural, guaiacol, 4-methylguaiacol, and 4-ethylguaiacol. In field experiments, A. candidatus was attracted to traps baited with a mixture of these fire-specific VOCs. EAG responses also revealed a dose response to three other VOCs like nonanal, 3octanone and 2(5H)-furanone. Moreover, IR receptors were found on the thoracic propleural region of A. candidatus. These IR receptors have an outer shape similar to other pyrophilous Aradus species like A. albicornis, A. lugubris and A. fuscicornis. The attraction of $A$. candidatus to fire-specific VOCs, the presence of IR receptors, and the observed behavior to approach recently burnt habitats illustrate a highly pyrophilous behavior in this Vietnamese flat bug species.
\end{abstract}

Keywords: burnt wood volatiles, Aradus candidatus, burnt habitat, IR receptors, flat bugs, forest fires, pyrophilous insects, photomechanic IR receptors 


\subsection{Introduction}

The ability to approach fires even from far distances and colonize freshly burnt areas in about 50 species of so-called pyrophilous insects is well known (Wikars 1997; Schmitz et al., 2008). Pyrophilous insects use fire-specific stimuli such as the smell of burning logs and probably also infrared (IR) radiation (Evans 1964; Wikars 1992; Schütz et al. 1999; Schmitz et al., 2008, 2010) as cues to approach fires.

Responses of antennal olfactory sensilla in pyrophilous insects to fire-specific volatile organic compounds (VOCs) measured by electro-antennographic (EAG) recording techniques have received increased attention in recent years (Paczkowski et al., 2013, 2014). These VOCs are released upon thermal degradation of cellulose, hemicellulose and lignin from plants during forest fires. There are several studies dealing with the EAG responses of pyrophilous insects to fire-specific VOCs such as Melanophila accuminata (Schütz et al., 1999), M. cuspidata (Paczkowski et al., 2013), Merimna atrata (Paczkowski 2013), and Acanthocnemus nigricans (Paczkowski et al., 2014). Moreover, several studies on the sensory adaptation of pyrophilous insects exist (Kreiss et al., 2005; Schmitz et al., 2008, 2010). The 12 species of the pyrophilous beetle genus Melanophila are equipped with IR receptors. Infrared receptors are located directly behind the coxae of the mesothoracic legs (Vondran et al., 1995; Schmitz et al., 2010). As a special feature, the IR sensilla of Melanophila beetles are innervated as mechanoreceptors and, therefore, have been termed photomechanic (Schmitz \& Bleckmann 1998). Astonishingly, photomechanic IR receptors strongly resembling IR sensilla in Melanophila beetles have also been found in flat bugs of the genus Aradus. In some pyrophilous Aradus species, IR receptors are distributed on the propleural region as in A. albicornis, A. lugubris and A. fuscicornis (Schmitz et al., 2008, 2010). ThiThAradus candidatus has been found on freshly burnt areas in Vietnam Central Highlands during our study conducted from February to April, 2017. This bug species was found on an independent field trip that is not part of the studies presented in the chapters. However, to the best of our knowledge, there is no study about pyrophilous behavior and fire-specific sensory adaptations of $A$. candidatus so far. Therefore, it is reasonable to examine the responses of antennal olfactory receptors to fire-specific volatiles and the presence of IR receptors in this species.

In electrophysiological investigations, we examined the EAG response of $A$. candidatus to VOCs including 3-octanone, nonanal, $2(5 \mathrm{H})$-furanone, guaiacol, 4-ethyl-guaiacol, hydroxyacetone and 5-methylfurfural. These VOCs have different functions and are used by pyrophilous insects for detecting wood fires. 3-octanone is also a volatile released typically by fungi (Holighaus et al., 2014). Nonanal is present in decaying material (Paczkowski et al., 2013). Guaiacol is released 
by the incomplete combustion of lignin (Sagebiel \& Seiber 1993; Schütz et al., 1999) and also known as an atmospheric marker for wood smoke (Schütz et al., 1999). Thus, it is a very important substance for pyrophilous insects. $2(5 \mathrm{H})$-furanone is known as VOC released by heated meat (Ansorena 2001; Ozkara et al., 2019). 4-ethyl-guaiacol is also released by the incomplete combustion of lignin (Piskorz et al., 1986; Flematti et al., 2004). Hydroxyacetone and 5-methylfurfural are products of the thermal degradation of cellulose and hemi-celluloses (Branca et al., 2006; Azeez et al., 2010). They play an important role in attracting pyrophilous insects (Paczkowski et al., 2013) and, therefore, are of interest to test the sense of smell of an insect to establish a potential pyrophilous biology. For the field test, we use the volatile mixtures of six compounds for the traps baited with VOCs including hydoxyacetone, 5-methylfurfural, guaiacol, 4-methylguaiacol, 4-ethylguaiacol and 2(5H)-furanone. We also built IR traps as described in Chapter 4 by Hoang et al., (manuscript, $14 \mathrm{pp}$ ) to show the importance of IR stimuli in A. candidatus. Finally, we examined the ventrolateral regions of the thorax and the abdomen of $A$. candidatus for putative IR receptors.

\subsection{Material and Methods}

\subsubsection{Insects}

Adult Aradus candidatus bugs were caught after fires on burnt forested areas in February to April 2017 in Kontum province, Vietnam. The live insects were stored in perforated boxes and transported to Germany. They were kept alive for two months in small plastic boxes filled with burnt $\operatorname{logs}$ naturally infested with post-fire fungi. The dead specimens were used for scanning electron microscopy. Some bugs were further sent to E. Heiss (Innsbruck, Austria) for identification to species level.

\subsubsection{Chemicals}

Eight chemical compounds hydroxyacetone, guaiacol, nonanal, 5-methylfurfural, 2(5H)furanone, 4-methylguaiacol, 4 ethylguaiacol and 3-octanone were diluted in silicon oil M 200 (w/w) (Carl Roth $\mathrm{GmbH}+$ Co. KG, Germany) for the EAG experiments. Six chemical compounds (>97\% purity) were used for traps baited with VOCs in the field including: hydroxyaceton, guaiacol, 5-methylfurfural, 2(5H)-furanone, 4-methylguaiacol and 4ethylguaiacol. All of these compounds were obtained from commercial suppliers. Hydroxyacetone, 3-octanone and 2(5H)-furanone were obtained from Sigma-Aldrich Co. (St. Louis, Missouri, USA), 5-methylfurfural from Acros Co. (Belgium, Wisconsin, USA), guaiacol 
from Fluka (Buchs, Switzerland) and 4-ethylguaiacol from SAFC Co. (St. Louis, Missouri, USA). All concentrates (> 97\% purity) were of analytical quality.

\subsubsection{EAG experiments}

Two drops of a diluted VOC were soaked onto a $2 \mathrm{~cm}^{2}$ filter paper for each dilution step. The soaked filter paper was placed into a $10 \mathrm{ml}$ glass syringe. The dose responses of the antennal sensilla were measured in an electro-antennographic (EAG) setup. This setup was described in detail by (Weißbecker et al., 2004). Before starting the experiments, an amplification factor of 10 was adjusted, resulting in a total amplification factor of 100. A corner frequency of the EAG signal was set to pass filtered at $10 \mathrm{~Hz}$. The corner frequency is set to a cutoff frequency. The low frequency at $1 \mathrm{~Hz}$ and the high frequency at $50 \mathrm{~Hz}$ was adjusted to pass filtered.

Shortly before a series of measurements, two wells of the antenna holder were filled with haemolymph Ringer solution (Kaissling \& Thorson 1980; Schütz et al., 1997). The excised antenna which was freshly removed from the bug, was mounted onto a canal bridge of the antenna holder. Then, the two ends of this antenna were contacted in the Ringer solution of the antenna holder's wells, so that the antenna formed a bridge between the two wells of the antennae holder.

Each EAG experiment was started by puffing $2.5 \mathrm{ml}$ of air from an empty glass syringe into a stream of humidified air $\left(500 \mathrm{ml} / \mathrm{min}, 23^{\circ} \mathrm{C}, 80 \%\right.$ relative humidity) (Paczkowski et al., 2013) passing over the antenna in the antenna holder. Afterwards, air from a glass syringe loaded with a filter paper containing paraffin oil was puffed in the same way over the antenna. In order to test the ability of the antennae to respond to the different compounds, air from a glass syringe loaded with the respective VOC at a concentration of $10^{-5}(\mathrm{mg})$ was puffed into the air stream. These concentrations are diluted in silicone oil. If responses could be elicited, air loaded with concentrations of $10^{-4}$, and $10^{-3} \mathrm{mg}$ of the tested compounds was applied. This was repeated three times for each dilution step, leaving two minutes of resting time between each single puff. The procedure was repeated with the same dilution steps of the six compounds listed above. With different insect antennae, the different orders of compounds were used for each antenna. Thus, depending on the range of the dilution steps, the total number of sample injections per antenna ranged from 27 to 30 . The signals were recorded and analyzed by the Agilent Chemstation software.

\subsubsection{Trap construction}

The construction of IR traps and VOC traps are described in chapter III of this thesis. 


\subsubsection{Field traps}

The experiments were carried out in secondary forest areas in Ngoc Reo forest, pine plantations (Pinus sp.), adjacent to the secondary forest of Chu Mom Ray National Park and inside the national park (Sa Thay district, Kon Tum province, Vietnam Central Highlands). The mean temperature at the study area was $21.8^{\circ} \mathrm{C}$ during the sample period (from February to April 2017). Field research was conducted during the dry season from 20 February to 14 April 2017, when frequent fires of natural and anthropogenic origin took place in the survey area.

Traps were set up in two different habitats, including unburnt and freshly burnt areas (from 1 10 days after the fire). The unburnt habitat was selected to provide an undisturbed reference of control samples. Whereas freshly burnt habitats were chosen for investigating the presence of the following groups of pyrophilous insects: 1) mating and oviposition on plants and fungi, 2) scavenging and oviposition on carrions of animals not being able to escape from the fire, and 3) preying or parasitizing on the former two groups. The trap setups were installed in a block design (Fig. 1), with three blocks arranged in a north-south line according to wind direction. The design was placed over a central area of at least $300 \mathrm{~m} \times 400 \mathrm{~m}$ to allow for space between the traps. To prevent down-wind effects, the first VOC trap was placed in the furthest southeast, $50 \mathrm{~m}$ away from the edge. The second VOC trap was installed in the furthest southwest, also $50 \mathrm{~m}$ from the edge. The IR trap with VOCs (mixed trap) was set up $100 \mathrm{~m}$ away from the first VOC trap in the northeast, whereas the IR trap was placed in parallel with the IRVOC trap and was installed $100 \mathrm{~m}$ away from the second VOC trap in the northwest. The design, construction and performance of the IR traps were described in detail by Hoang et al. (manuscript, $14 \mathrm{pp}$ ). Two control traps were set up in the furthest northeast and northwest respectively. These traps were suspended $1 \mathrm{~m}$ above ground. They were used in both unburnt and freshly burnt habitats. Each trap was active for 15 hours per day from 6:00 to 22:00 hours over 10 days resulting in total of 11 replicates. After each day, the VOC mixture was renewed. Every second day, traps were placed on a new site. Insects were monitored every three hours and contents of the traps were transferred to plastic boxes. Captured insects were sorted to morphologically similar groups and killed with ethyl-acetate before being labeled and stored in 50\% ethanol. Specimens from both traps were sent to the Department of Insect Systematics at the Institute of Ecology and Biological Resources (IEBR) in Hanoi, Vietnam, for identification. 


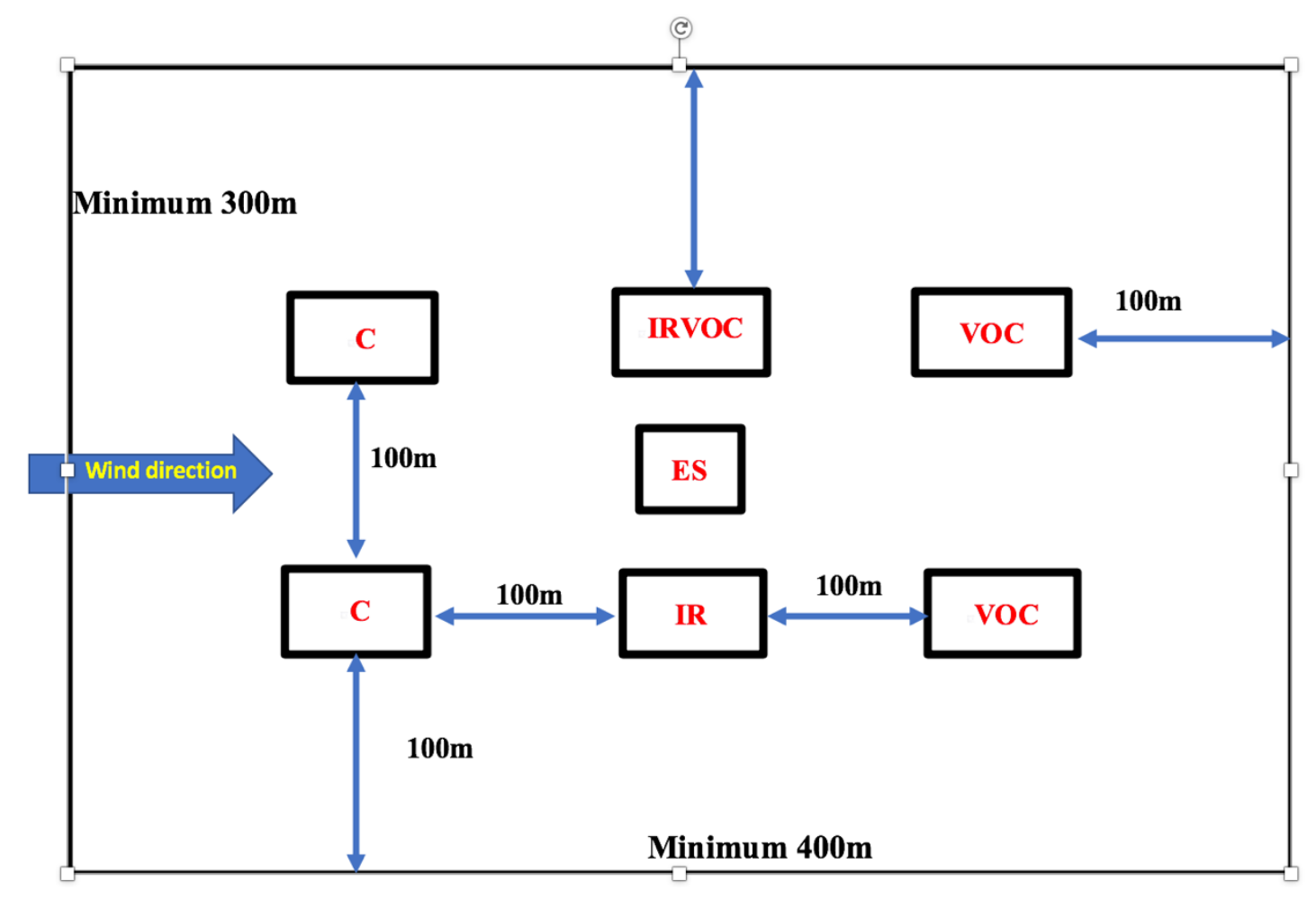

Figure 1: Symmetric drawing of the study design in Vietnam Central Highlands in 2017. C: Empty control traps. IR: Traps emitting IR radiation. IRVOC: Traps emitting IR radiation and contained a mixture of fire-specific volatile organic compounds. VOC: Traps baited with a mixture of fire-specific volatile organic compounds. ES: Electric supplier.

\subsubsection{Scanning electron microscopy (SEM)}

Bugs fixed in $70 \%$ ethanol were cleaned by sonication in a mixture of chloroform and ethanol (2:1) for 2 min. After drying in air, specimens were glued onto holders with carbon glue (LeitC, Fa. Neubauer), sputtered with gold, and examined in a LEO 440i (Leica, Bensheim, Germany) scanning electron microscope (SEM).

\subsubsection{Data analysis}

The EAG responses to fire-specific VOCs were normalized by comparing them to the EAD responses of the silicon oil control. We subtracted the mean of the blank responses before and after the measurements which were elicited by the antennae to the control stimuli (silicone).

The EAG-responses to selected compounds were checked for significant differences between the tested concentrations at dilutions of $10^{-3}, 10^{-4}$ and $10^{-5}$ by Kruskal-Wallis ANOVA test, because data did not show a normal distribution. Dunn's test was used as a post hoc procedure following rejection of a Kruskal-Wallis test ( $\mathrm{R}$ studio, version 1.1.463). The Wilcoxon rank- 
sum test was used to check for significant differences between numbers of insects caught in each trap. The significance level (P value) was set at 5\%.

\subsection{Results}

\subsubsection{Attraction to different types of traps on burnt areas}

A total of 68 individuals of $A$. candidatus were caught by all traps, whereas only one $A$. candidatus was captured by the control traps. Two volatile traps yielded 25 individuals of $A$. candidatus, the two IR traps 18 individuals and the IRVOC traps 25 individuals. No significant differences between numbers of bugs caught in these three traps exist (Fig. 2). However, the numbers of bugs caught by VOC, IR and IRVOC traps were significantly different from the number of bugs (1) caught in the control traps $(\mathrm{P}=0.003465,0.002654$ and 0.001843 respectively, Wilcoxon rank sum test).

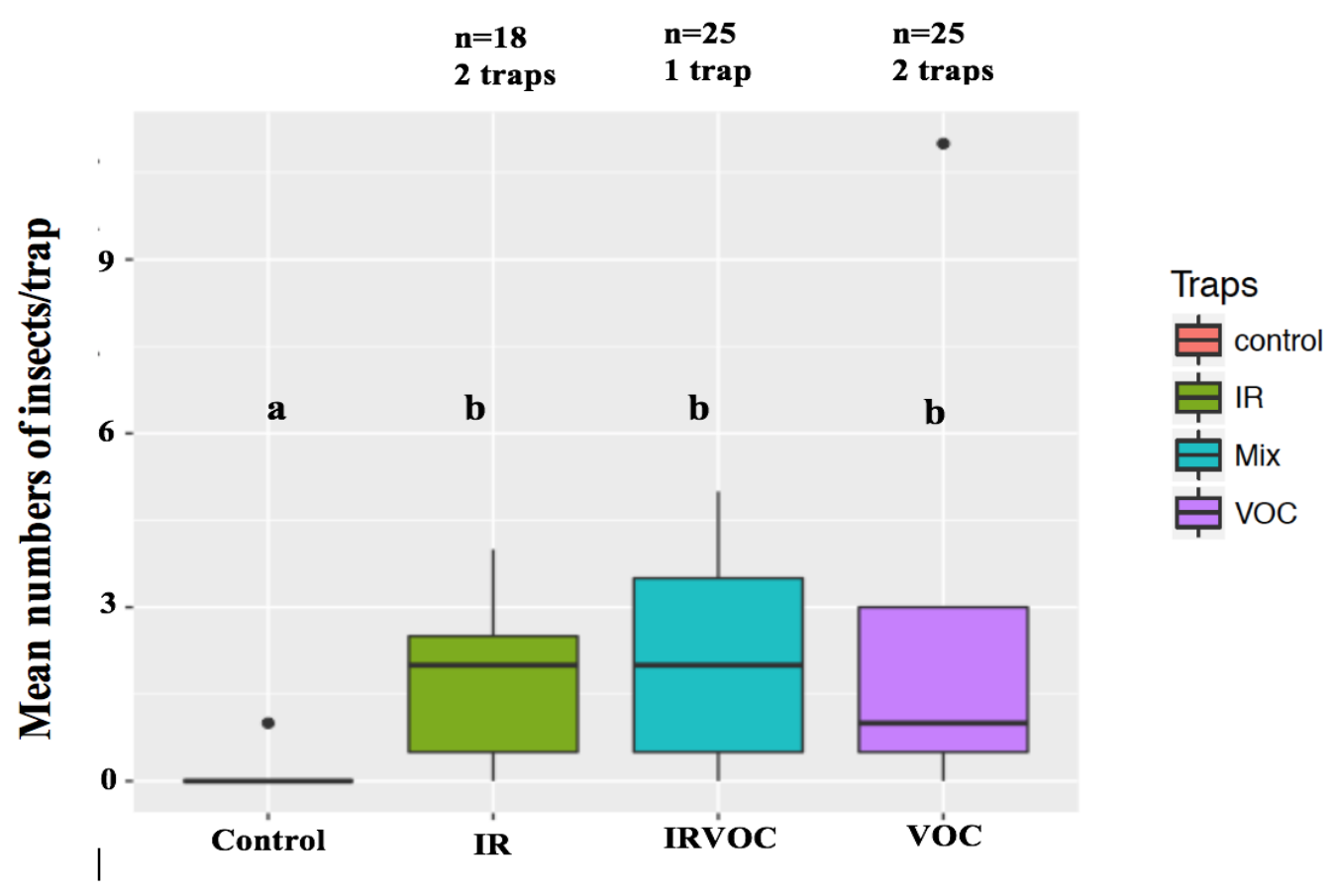

Type of Traps

Figure 2: Aradus candidatus caught by different types of traps: Control: control traps, IR: traps emitting IR radiation, VOCs: traps baited with a mixture of fire-specific volatile organic compounds. IRVOCs: traps emitting IR radiation and containing a mixture of fire-specific volatile organic compounds. Bars and whiskers display the median, upper and lower quartiles, as well as maxima and minima. The dots display outliers representing an abnormal number of $A$. candidatus caught by these traps. Different letters indicate significant differences among insects caught by each type of trap $(\mathrm{P}<0.05$, Wilcoxon rank sum test). 


\subsubsection{EAG responses of $\boldsymbol{A}$. candidatus antennae to fire-specific volatile organic compounds}

The normalized EAG responses of the A. candidatus antennae to hydroxyaceton, guaiacol, nonanal, 5-methylfurfural, 2(5H)-furanone, 4-methylguaiacol, 4-ethylguaiacol and 3-octanone at three doses $\left(10^{-5}\right.$ to $10^{-3}$ diluted in silicon oil $(\mathrm{mg})$ are shown in Fig. 3. Hydroxyaceton, guaiacol, nonanal, 5-methylfurfural, and 2(5H)-furanone showed clear dose responses down to the $10^{-5}$ dilution. 4-methylguaiacol showed a clear dose response between $10^{-4}$ and $10^{-3}$ doses. 4-ethylguaiacol and 3-octanone elicited very high dose responses between $10^{-5}$ and $10^{-4}$ dose (Fig. 3).

When comparing the normalized EAG responses of $A$. candidatus of all eight volatile compounds at the three doses tested $\left(10^{-3}, 10^{-4}\right.$ and $\left.10^{-5}\right)$ the highest response to 3-octanone and 4-methylguaiacol respectively was recorded at a dose of $10^{-3}$. These compounds showed significantly higher responses than 4-ethyl-guaiacol ( $\mathrm{P}<0.05$, Dunn test). At a dose of $10^{-4}$, significantly higher EAG response amplitudes of 3-octanone, 4-methylguaiacol, hydroxyacetone and 5-methylfurfural in comparison to 4-ethyl-guaiacol and $2(5 \mathrm{H})$-furanone were measured $\left(\mathrm{P}<0.05\right.$, Dunn test). At a dose of $10^{-5}$, the highest EAG response amplitudes to 3-octanone, 4-methylguaiacol and hydroxyaceton occured. These compounds were significantly more effective than 4-ethylguaiacol ( $\mathrm{P}<0.05$, Dunn test). The EAG response amplitudes of the $A$. candidatus antenna to 4-ethyl-guaiacol at $10^{-3}$ and $10^{-5}$ dilutions were the lowest of all compounds (Fig.3). The EAG response amplitudes to $2(5 \mathrm{H})$-furanone at $10^{-4}$ were the lowest of all compounds. 


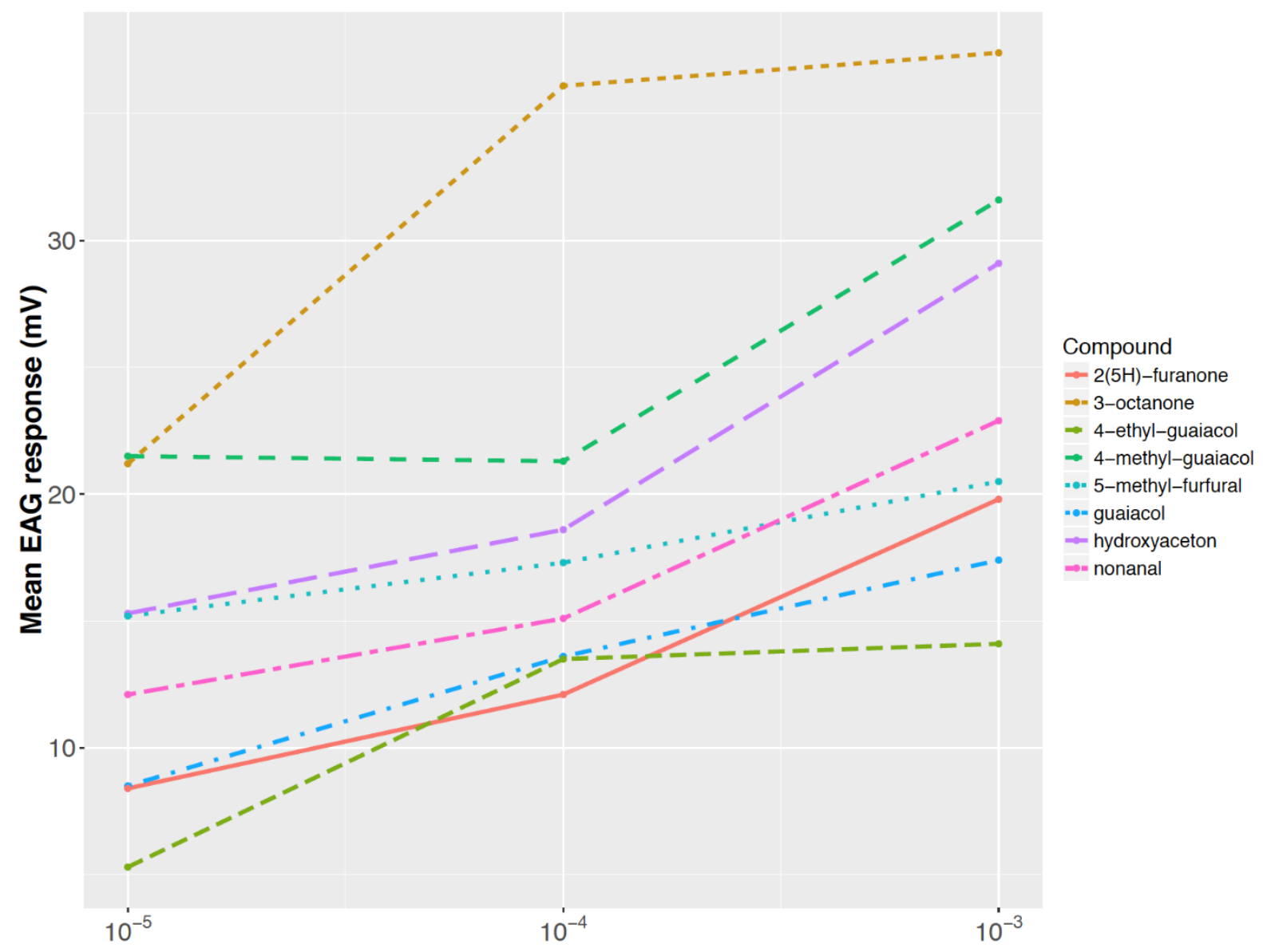

$\log _{10}$ dilution in silicone oil (mg/mg)

Figure 3: EAG responses of A. candidatus to selected fire-specific VOCs.

\subsubsection{Propleural IR receptors}

A low number of presumed IR sensilla were found on the lateral regions of the prothorax (the propleurae). IR receptors are distributed between the hair mechanoreceptors which exhibit bollard-like bases and a short lateral peg (Fig. 4A overview image). The outer cuticular apparatus of an IR sensillum consists of a dome-shaped hemisphere and a small apical recess (Fig. 4B image with details). The distribution and outer shape of IR sensilla in A. candidatus are similar to the IR sensilla found in other pyrophilous Aradus species (Schmitz et al., 2010). 

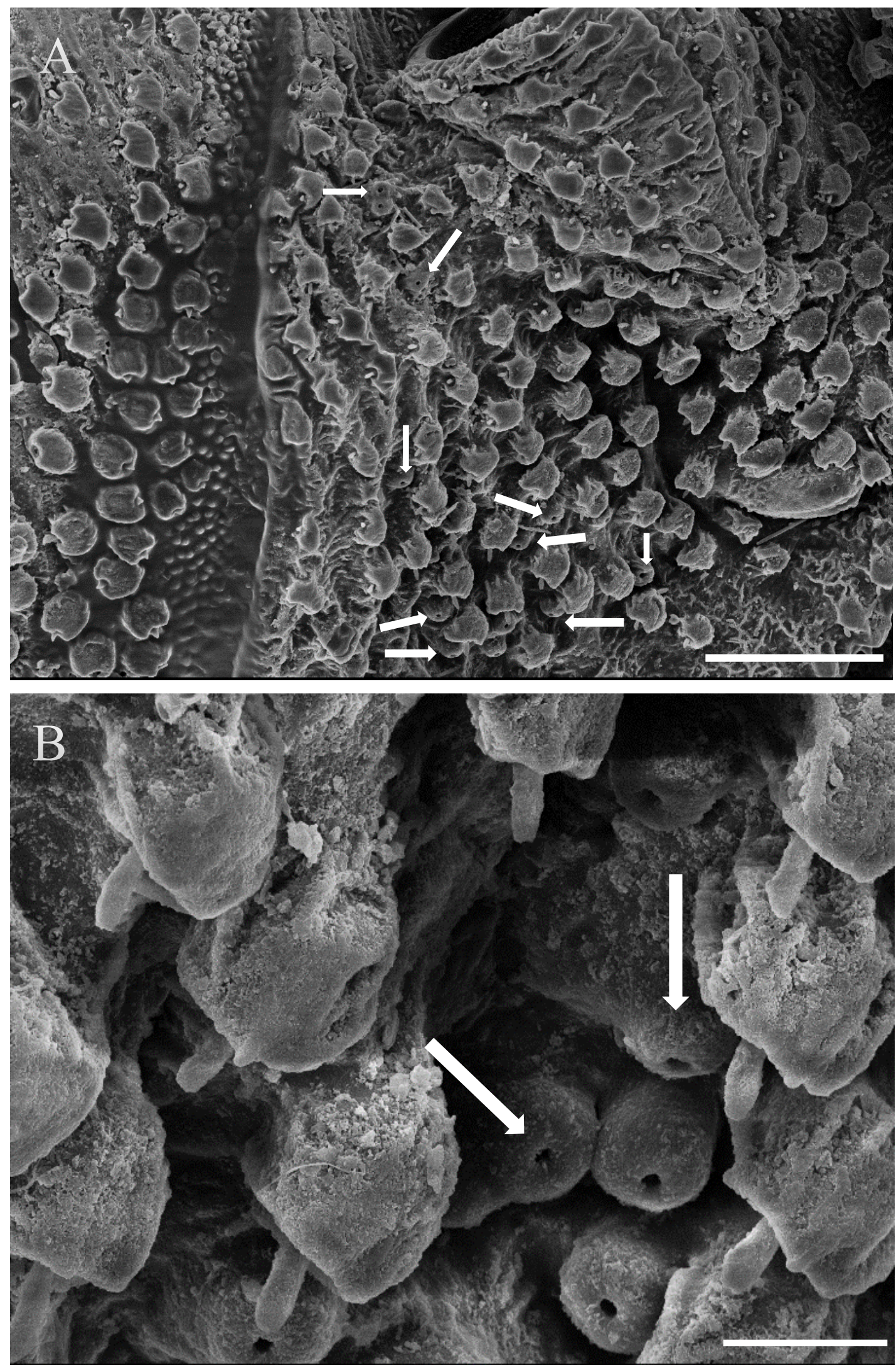

Figure 4: (A) View of the propleural region of Aradus candidatus with some IR sensilla on the area directly posterior to the base of the left prothoracic leg, bar $100 \mu \mathrm{m}$. (B) grouped IR sensilla surrounded by mechanoreceptors. Bar $20 \mu \mathrm{m}$. White arrows mark some IR sensilla. 


\subsection{Discussion}

A major aspect of this study was to examine the presumed pyrophilous behavior and the corresponding sensory adaptations of $A$. candidatus in Vietnam. EAG responses of isolated antennae and field traps set up on freshly burnt areas were used to find evidence for a pyrophilous biology. Moreover, A. candidatus obviously possesses IR sensilla in the propleural region. Altogether, this demonstrates the highly pyrophilous behavior of $A$. candidatus.

\subsubsection{Attraction to a mixture of fire-specific VOCs}

We were able to confirm that the fire-specific VOCs hydroxyacetone, 5-methylfurfural, guaiacol, 4-methylguaiacol, and 4-ethylguaiacol can be perceived dose-dependent. The attraction of $A$. candidatus towards these compounds is confirmed by our field studies with traps baited with mixtures of fire-specific VOCs. Also other pyrophilous insects are attracted by the tested VOCs, e. g. Melanophila cuspidata (except for 4-ethyl-guaiacol) and Acanthocnemus nigricans (except for guaiacol), which has been confirmed by lab and field tests in previous studies (Tab. 1). Moreover, it was demonstrated that the pyrophilous beetle Merimna atrata perceived 5-methylfurfural, guaiacol and 4-ethylguaiacol as shown by (Paczkowski, 2013) (Tab. 1). The EAG response of the pyrophilous beetle Melanophila accuminata to guaiacol was investigated by (Schütz et al., 1999) (Tab. 1). 
Table 1: Response of pyrophilous insect species to different compounds according to the literature. References: A: Paczkowski et al., 2013; B: Paczkowski 2013; C: Paczkowski et al., 2014; D: Schütz et al., 1999. GC-MS/EAD: gas chromatography - mass spectrometry/ electroantennographic detector. EAG: electroantennography.

\begin{tabular}{|c|c|c|c|c|}
\hline Compound & $\begin{array}{l}\text { Melanophila } \\
\text { accuminata }\end{array}$ & $\begin{array}{l}\text { Melanophila } \\
\text { cuspidata }\end{array}$ & $\begin{array}{l}\text { Merimna } \\
\text { atrata }\end{array}$ & $\begin{array}{l}\text { Acanthocnemus } \\
\text { nigricans }\end{array}$ \\
\hline Hydroxyacetone & & A & & $\mathrm{C}$ \\
\hline Furfural & & A & $\mathrm{B}$ & \\
\hline 2-Furanmethanol & & A & $\mathrm{B}$ & \\
\hline 5-methylfurfural & & A & $\mathrm{B}$ & $\mathrm{C}$ \\
\hline Guaiacol & $\mathrm{D}$ & A & $\mathrm{B}$ & \\
\hline $\begin{array}{l}\text { 4- } \\
\text { Methylguaiacol }\end{array}$ & & A & & $\mathrm{C}$ \\
\hline 4-Ethylguaiacol & & & $\mathrm{B}$ & $\mathrm{C}$ \\
\hline Syringol & $\mathrm{D}$ & & & \\
\hline Lab test & EAG (B) & $\begin{array}{l}\text { GC-MS/EAD, } \\
\text { EAG (A), } \\
\text { Behavior } \\
\text { confirmation } \\
\text { using } \\
\text { olfactometer (A) }\end{array}$ & $\mathrm{EAG}(\mathrm{B})$ & $\begin{array}{l}\text { Olfactometer } \\
\text { (A) }\end{array}$ \\
\hline Field test & & & & $\begin{array}{l}\text { Behavior } \\
\text { confirmation } \\
\text { using traps } \\
\text { baited with } \\
\text { VOCs }(\mathrm{C})\end{array}$ \\
\hline
\end{tabular}

As shown in Tab. 1, fire-specific VOCs are not known to be perceived by all pyrophilous insects. Instead, non-pyrophilous insects may respond to the fire-specific VOCs too. For example, Nauphoeta cinerea use 4-methylguaiacol as a sex pheromone in male insects (Abed et al., 1993). This shows that not every insect perceiving fire-typical compounds has necessarily to be pyrophilous. This is the reason why we tested the responses of pyrophilous insects with a mixture of more than one fire-specific compound.

Our EAG results demonstrated that olfactory sensillae on the antennae of A. candidatus can perceive dose-response volatiles emitted by decaying material like nonanal (Paczkowski et al., 2012) and the fungal volatiles 3-octanone (Holighaus et al., 2014). Further experiments are needed to test the attraction of $A$. candidatus to these compounds. However, it is reasonable to 
suppose that A. candidatus is attracted to 3-octanone because A. candidatus colonizes the burnt trees and presumably feeds on fast-growing post-fire fungi (Heliövaara and Väisänen 1983; Coulianos 1989; Wikars 1992). Therefore, the fungal volatile 3-octanone may play an important role for them to find their food sources. Additionally, for the first time, a dose-depended EAG response of an A. candidatus antenna to the heated meat VOC 2(5H)-furanone (Ansorena et al., 2001; Ozkara et al., 2019) could be shown in our study. Because carnivorous pyrophilous insects might be attracted to the heated meat volatites, therefore this compound was used.

The attraction of $A$. candidatus to our mixture of fire-specific VOCs containing $2(5 \mathrm{H})$-furanone is confirmed. Further studies are needed to reveal the behavior of $A$. candidatus toward $2(5 \mathrm{H})-$ furanone.

Our results demonstrate that the number of $A$. candidatus caught by traps with a combined stimulus (i. e., VOCs and IR radiation) was higher than in traps baited only with VOCs or IR radiation. A possible explanation may be that $A$. candidatus is also equipped with IR receptors and, therefore, more fire-specific receptors are stimulated resulting in a stronger behavioral response. Additionally, it can be postulated that $A$. candidatus uses its IR receptors for a safe landing near hot spots (Schmitz et al., 2008, 2010). Furthermore, our study demonstrates an attraction of $A$. candidatus to IR radiation alone and a combined IRVOCs stimulus for the first time. The attraction of the pyrophilous beetle A. nigricans to several fire-specific VOCs had been previously studied by (Paczkowski et al., 2014) also demonstrating the attraction to firespecific VOCs (Tab. 1). Although A. nigricans has been found in the investigated area in Vietnam (Hoang \& Schütz 2015; Hoang et al., manuscript (21 pp.), Geiser 2016) we could not capture this pyrophilous species with our traps. A possible reason may be, that our VOC mixture contained some VOCs different from the mixtures used by Paczkowski et al. (2014) in former field tests. This may suggest that A. nigricans may be repelled by one of our compounds. Further experiments are needed to confirm this speculation.

\subsubsection{Structure and functions of IR receptors}

The presence of IR receptors on the thorax of $A$. candidatus could explain why the bug is attracted by traps emitting IR radiation (alone or in combination with VOCs). Similar thoracic IR receptors have been found in three other aradid bugs including A. albicornis (Schmitz et al., 2008), A. lugubris and A. fuscicornis (Schmitz et al., 2010). This suggests that IR sensilla of $A$. candidatus might have a similar function like in other pyrophilous Aradus species (Schmitz et al., 2008, 2010). 
The ultrastructure of the IR sensilla in A. candidatus has not been examined in our study. However, based on the similarity of the cuticular apparatus to the IR receptors found in Aradus albicornis (Schmitz et al., 2008), A. lugubris and A. fuscicornis (Schmitz et al., 2010), a socalled photomechanic function can be proposed. Interestingly, the structure and function of the IR receptors in pyrophilous Aradus species is highly reminiscent to the IR receptors found in the thoracic pit organs of pyrophilous Melanophila beetles (Schmitz \& Bleckmann 1997). In contrast, the IR sensilla of Aradus bugs are not confined in a pit but are interspersed between hair mechanoreceptors (Schmitz et al., 2008, 2010).

Some of our data gathered in the field from 2014-2017 (not published) showed that there are a number of insects with a presumed pyrophilous way of life which have been caught in small numbers in the trap baited with the combination of IR and fire-specific VOCs. This may be in line with previous studies that not all pyrophilous species have IR receptors (Schmitz et al., 2010). These pyrophilous species may use their olfactory abilities to detect the fire from far distances. Instead, IR receptors have been found in some species that have not been described as pyrophilous insects (Schmitz et al., 2010). What may drive the spectacular morphological and physiological development of hitherto non-pyrophilus insects into pyrophilous species? This question could serve as a starting-point for further studies.

\subsection{Conclusion}

We could demonstrate that $A$. candidatus elicits responses towards our mixtures of fire-specific VOCs including hydroxyacetone, 5-methylfurfural, guaiacol, 4-methylguaiacol, 4ethylguaiacol what has been confirmed by EAG recordings from isolated antennae and field experiments. IR receptors are found on the propleural region of A. candidatus. These IR receptors have an outer shape similar to those found in other Aradus specices like A. albicornis, A. lugubris and A. fuscicornis. The response of A. candiatus to fire-specific VOCs, the presence of IR receptors, and the species' occurrence at recently burnt habitats, immediately after fire, illustrate a highly pyrophilous behavior of this bug species.

The perception of fire-specific VOCs and IR receptors in pyrophilous insects are subject of current studies for their role in fire detection and orientation on freshly burnt areas. Further studies might reveal the interaction of different senses used to perceive fire-specific VOCs (olfaction) and IR radiation in pyrophilous insects. Moreover, the selective forces responsible for the remarkable morphological and physiological development of hitherto non-pyrophilous insects into pyrophilous species should be studied further. 


\subsection{Acknowledgements}

We would like to thank Sara Nicke, Urike Eisenwiener, Karthi Balakrishnan and Andreas Teichmann for helpful technical support during our lab tests. We would like to thank all Vietnamese students and workers who help us during collection of field data in Vietnam. We are grateful to the forest protection department of Kon Tum province to give the permission to our work and for the transport of living insects to Germany. We are indebted to E. Heiss (Innsbruck, Austria) for the determination of A. candidatus. Prof. Dr. Stefan Schütz contributed his ideas to this study. The work of Thi Phuong Hoang was kindly supported by KAAD (Katholischer Akademischer Ausländer-Dienst). 


\subsection{References}

Abed, D., Brossut, R. and Farine, J.-P. (1993). Evidence for sex pheromones produced by males and females in Blatta orientalis (Dictyoptera, Blattidae). Journal of Chemical Ecology, 19(12): 2831-2853.

Ansorena, D., Gimeno, O., Astiasarán, I. and Bello, J. (2001). Analysis of volatile compounds by GC-MS of a dry fermented sausage: chorizo de Pamplona. Food Research International, 34(1): 67-75.

Azeez, A. M., Meier, D., Odermatt, J. and Willner, T. (2010). Fast pyrolysis of African and European lignocellulosic biomasses using Py-GC/MS and fluidized bed reactor. Energy \& Fuels, 24(3): 2078-2085.

Branca, C., Di Blasi, C. and Elefante, R. (2006). Devolatilization of conventional pyrolysis oils generated from biomass and cellulose. Energy \& Fuels, 20(5): 2253-2261.

Coulianos, C. C. (1989). New provincial records of Swedish flatbugs and barkbugs (Hem. Het., Aradidae) with Aradus truncatus FIEBER, 1861, new to Sweden. Entomologisk tidskrift, 110(1-2): 53-57.

Evans, G. (1964). Infra-red receptors in Melanophila acuminata DeGeer. Nature, 202: 211.

Flematti, G. R., Ghisalberti, E. L., Dixon, K. W. and Trengove, R. D. (2004). A compound from smoke that promotes seed germination. Science, 305(5686): 977.

Geiser, M. (2016). An update on the distribution of the pyrophilous beetle Acanthocnemus nigricans (Hope, 1845) (Coleoptera: Cleroidea: Acanthocnemidae), including new records from Laos. Entomologica Basiliensia et Collectionis Frey, 35: 429-432.

Heliövaara, K. and Väisänen, R. (1983). Environmental changes and the flat bugs (Heteroptera, Aradiae and Aneuridae). Distribution and abundance in Eastern Fennoscandia. Annales Entomologici Fennici, 49(4): 103-109.

Hoang, T. P. and Schütz, S. (2015). Pyrophilous Insects in Vietnam Central Highlands. Mitteilungen Deutsche Gesellschaft für allgemeine und angewandte Entomologie, 20: 133-138.

Hoang, T. P., Holighaus, G., and Schmitz, H. (Manuscript). Pyrophilous insects response to different stimuli. $14 \mathrm{pp}$.

Hoang, T.P., Schmitz, H., Holighaus, G. (Manuscript). Do volatiles released upon heating of different species of Vietnamese woody plants attract pyrophilous insects? $21 \mathrm{pp}$.

Holighaus, G., Weißbecker, B., von Fragstein, M. and Schütz, S. (2014). Ubiquitous eightcarbon volatiles of fungi are infochemicals for a specialist fungivore. Chemoecology, 24(2): 57-66.

Kaissling, K. and Thorson, J. (1980). Insect olfactory sensilla: structural, chemical and electrical aspects of the functional organisation. Pp. 261-282 in: Sattelle. D. B., Hall, L. M. and 
Hildebrand, J. G. (eds): Receptors for neurotransmitters, hormones and pheromones in insects. Amsterdam, Elsevier/North-Holland, 310 pp.

Kreiss, E.-J., Schmitz, A. and Schmitz, H. (2005). Morphology of the prothoracic discs and associated sensilla of Acanthocnemus nigricans (Coleoptera, Acanthocnemidae). Arthropod Structure and Development, 34(4): 419-428.

Ozkara, K. T., Amanpour, A., Guclu, G., Kelebek, H. and Selli, S. (2019). GC-MSOlfactometric differentiation of aroma-active compounds in Turkish heat-treated sausages by application of aroma extract dilution analysis. Food Analytical Methods, 12(3): 729-741.

Paczkowski, S., Paczkowska, M., Maibaum, F. and Schütz, S. (2012). Decaying mouse volatiles perceived by Calliphora vicina Rob.-Desv. Journal of Forensic Sciences. 57(6): 14971506.

Paczkowski, S. (2013). Insect olfaction as an information filter for chemo-analytical applications. PhD Thesis. Faculty of Forest Sciences and Forest Ecology. University of Göttingen, Germany.

Paczkowski, S., Paczkowska, M., Dippel, S., Schulze, N., Schütz, S., Sauerwald, T., et al. (2013). The olfaction of a fire beetle leads to new concepts for early fire warning systems. Sensors and Actuators, B: Chemical, 183: 273-282.

Paczkowski, S., Paczkowska, M., Dippel, S., Flematti, G. and Schütz, S. (2014). Volatile combustion products of wood attract Acanthocnemus nigricans (Coleoptera: Acanthocnemidae). Journal of Insect Behaviour, 27(2): 228-238.

Piskorz, J., Radlein, D. and Scott, D. S. (1986). On the mechanism of the rapid pyrolysis of cellulose. Journal of Analytical and Applied Pyrolysis, 9(2): 121-137.

Sagebiel, J. C. and Seiber, J. N. (1993). Studies on the occurrence and distribution of wood smoke marker compounds in foggy atmospheres. Environmental Toxicology and Chemistry, 12(5): 813-822.

Schmitz, H. and Bleckmann, H. (1997). Fine structure and physiology of the infrared receptor of beetles of the genus Melanophila (Coleoptera: Buprestidae). International Journal of Insect Morphology and Embryology, 26(3-4): 205-215.

Schmitz, H. and Bleckmann, H. (1998). The photomechanic infrared receptor for the detection of forest fires in the beetle Melanophila acuminata (Coleoptera: Buprestidae). Journal of Comparative Physiology, 182(5): 647-657.

Schmitz, A., Gebhardt, M. and Schmitz, H. (2008). Microfluidic photomechanic infrared receptors in a pyrophilous flat bug. Naturwissenschaften, 95(5): 455-460.

Schmitz, A., Schätzel, H. and Schmitz, M. (2010). Distribution and functional morphology of photomechanic infrared sensilla in flat bugs of the genus Aradus (Heteroptera, Aradidae). Arthropod structure \& development 39(1): 17-25. 
Schütz, S., Weißbecker, B., Hummel, H. E., Schöning, M. J., Riemer, A., Kordos, P., et al., (1997a). Field effect transistor-insect antenna junction. Naturwissenschaften, 84: 86-88.

Schütz, S., Weißbecker, B., Klein, A. and Hummel, H. E. (1997b). Host plant selection of the Colorado potato beetle as influenced by damage induced volatiles of the potato plant. Naturwissenschaften, 84: 212-217.

Schütz, S., Weißbecker, B., Hummel, H. E., Apel, K.-H., Schmitz, H. and Bleckmann, H. (1999). Insect antenna as a smoke detector. Nature, 398: 298-299.

Vondran, T., Apel, K.-H. and Schmitz, H. (1995). The infrared receptor of Melanophila acuminata De Geer (Coleoptera: Buprestidae): ultrastructural study of a unique insect thermoreceptor and its possible descent from a hair mechanoreceptor. Tissue and Cell, 27(6): 645-658.

Weißbecker, B., Holighaus, G. and Schütz, S. (2004). Gas chromatography with mass spectrometric and electroantennographic detection, analysis of wood odorants by direct coupling of insect olfaction and mass spectrometry. Journal of Chromatography A, 1056(1-2): 209-216.

Wikars, L.O. (1992). Skogsbränder och insekter. Entomologisk Tidskrift, 133(4): 1-11.

Wikars, L.O. (1997). Effects of forest fire and the ecology of fire-adapted insects. Comprehensive Summaries of Uppsala Dissertations from the Faculty of Science and Technology 272. Acta Universitatis Upsaliensis, Uppsala, Sweden, 272 pp. 


\section{Chapter 6}

\section{Adaptation of pyrophilous insects to burnt habitat: General discussion and conclusion}

\subsection{Presence of pyrophilous insects in Vietnam}

By hand collection in the smoldering logs, we could collect hundreds of specimens of several beetle species. The question arises whether those are pyrophilous? Pyrophilous species are distributed worldwide, for example in Europe, North America, and Australia. We suprisingly caught Acanthocnemus nigricans (Acanthocnemidae) a pyrophilous beetle that was thought to be restricted to the Australian continent in our study area in Vietnam (chapter 2 and 3). This is in line with a recent study of the presence and distribution of A. nigricans in Southeast Asia (Geiser 2016) that speculates about the benefits of slash-and-burn agricultural practice for pyrophilous species. While for Vietnam museal records of $A$. nigricans trace back to the years 1909 and 1912 (Geiser 2016), surprisingly, this species has not yet been caught by traps baited with a mixture of fire-specific VOCs or by traps emitting IR radiation. However, this species is known to be attracted by traps baited with VOCs in Australia (Paczkowski et al., 2013), and it is also known that it possesses IR receptors (Schmitz et al., 2002).

For the first time, the pyrophilous nature of the flat bug species Aradus candidatus is confirmed through this study (chapter 5). Like other pyrophilous insect species, A. candidatus immediately approaches open flames (own observation). Moreover, the EAG dose-response relationships indicates an olfactory response of A. candidatus to several fire-specific VOCs (chapter 5), including hydroxyacetone, guaiacol, 5-methylfurfural, 4 methylguaiacol, 4-ethylguaiacol, and $2(5 \mathrm{H})$-furanone. Field experiments confirmed that $A$. candidatus is attracted by traps baited with a mixture of such fire-specific VOCs. Another factor that contributed to conclusively demonstrate the pyrophilous nature of $A$. candidatus is the presence of IR receptors on the thorax. This is especially supported by the observation that A. candidatus was lured to traps emitting IR radiation (alone or in combination with VOCs) (chapter 5). While the attractiveness of IR radiation has never been tested, it has been demonstrated that other pyrophilous insect species such as A. nigricans, Merimna atrata and Melanophila acuminata showed the same behavior towards smoldering logs and fire-specific VOCs (Paczkowski et al., 2013). Likewise, these pyrophilous insect species also possess IR receptors (Schmitz et al., 2000, 2002, 2007). The observed IR receptors in A. candidatus are similar to the thoracic IR receptors in three other 
aradid bugs including A. albicornis (Schmitz et al., 2008), A. lugubris and A. fuscicornis (Schmitz et al., 2010), supporting their proposed function and a pyrophilous lifestyle.

\subsection{Diversity of VOCs and insects in recently burnt habitats (chapter 3)}

Volatile organic compounds play an important role for basic needs of insects such as mating (Pelosi \& Maida 1995), oviposition (Verheggen et al., 2008), finding food resources (Beck et al., 2012), or interspecific communication (Reyes-Vidal 2009). Many volatile compounds are emitted from different sources, while sharing similar chemical bases such as fundamental metabolisms (Bruce et al., 2005; Schoonhoven et al., 2005; Kües \& Navarro-Gonzales 2009). Volatile organic compound emissions and degradation products of wood constituents differ between and among tree species, and even within the same tree (Kollmann 1982; Hyttinen et al., 2010). Burning adds another source of variability, that results in a diversity of burnt wood VOCs and also typical species-specific chemical profiles (chapter 3). Burnt wood VOCs are, therefore, classified according to species and temperature in chapter 3 as 1), a group of common VOCs released by all four woody species. 2), a group of VOCs released only at certain temperatures (at $250^{\circ} \mathrm{C}$ or $300^{\circ} \mathrm{C}$ ), and 3), a group of VOCs released only by a specific tree species. Volatile organic compounds play an important role for pyrophilous insects to orient themselves toward fires (Schütz et al., 1999). Therefore, the diversity of insects in burnt habitats might be associated with the diversity of burnt wood VOCs. This specificity is emphasized by the attraction responses of insects on burnt habitats to the VOC-baited traps described in chapter 3. According to the literature, guaiacol and 5-methylfurfural are perceived by several pyrophilous insect species like the beetles Melanophila cuspidata, Merimna atrata and A. nigricans (Schütz et al., 1999; Paczkowski et al., 2013, 2014). Guaiacol is also perceived by Melanophila acuminata (Paczkowski et al., 2013). Furthermore, insect species in this study were also attracted by a VOC mixture containing guaiacol (chapters 3,4 and 5). This suggests that guaiacol and 5-methylfurfural may play a role as general VOCs for insects to detect and fly towards burnt habitats. Therefore, insect species attracted to our mixture containing guaiacol and 5-methylfurfural might be generalistic pyrophilous insects. In contrast, hydroxyacetone and 4-ethyl-guaiacol are only perceived by certain species. For example, M. cuspidata and $A$. nigricans perceive hydroxyacetone (Paczkowski et al., 2013, 2014), while M. atrata and A. nigricans perceive 4-ethylguaiacol (Paczkowski et al., 2013, 2014). Although released by burnt wood (chapter 3), hydroxyacetone is found in the fermentation product of wood sap (Ômura et al., 2000). Guaiacol is also produced by deadwood or maybe by microorganisms (Holighaus 2006). Similarly, 5-methylfurfural is a fermentation/vinegar related compounds used to lure the 
non-pyrophilous fruit fly Drosophila melanogaster (Becher et al., 2010). As it has not been known to be emitted by other sources, 4-ethyl-guaiacol is considered as a true smoke volatile, which can be also perceived by human olfaction. This compound could function as fire-specific marker for specialized insects and govern the burnt host-tree selection. Other insects may benefit from increased microbial activity and an increased amount of deadwood in burnt areas, characterized by the former compounds (Holighaus 2006). The perception of burnt wood VOCs by a variety of insect species in burnt habitat suggests a link between the chemo-diversity of plant combustion products and the biodiversity of insects. The diversity of insects found in burnt habitats may also be related to their feeding habits: several saproxylic fungivorous insect species were attracted by our mixture of fire-specific VOCs. As expected, these taxa (Cartodere sp. (Lathridiidae) and Litargus species (Mycetophagidae) (Cocciufa et al., 2014) (chapters 3 and 4)) might be attracted to guaiacol because this compound is also produced by deadwood (Holighaus 2006). Hydroxyacetone is found in the fermentation products of wood sap (Ômura et al., 2000). Therefore, this compound alone is not fire-specific. Hence, the pyrophilous behavior of insects in burnt habitat based on their VOCs perception should be interpreted with care.

\subsection{Are burnt wood VOCs a cue for pyrophilous insects to find burnt habitat?}

The attraction response of the pyrophilous flat bug A. candidatus to burnt wood VOCs such as hydroxyacetone, 5-methylfurfural, guaiacol and 4-ethylguaiacol has been emphasized (chapter 5). There is strong evidence that pyrophilous insects like Merimna atrata and A. nigricans (Paczkowski et al., 2013, 2014), as well as Melanophila cuspidata (Schütz et al.,1999; Paczkowski et al., 2013, 2014) showed attraction responses to these VOCs. VOCs also play an important role in host-finding in herbivorous insects (Bernays \& Chapman 1994), saproxylic and fungivorous insects (Holighaus 2012), or also in pyrophilous insects (Schütz et al., 1999). There are evidences that VOCs released during the thermal degradation of cellulose and lignin in this study, come from different sources as well. For example, these so-called fire-specific VOCs can also be perceived by insect species with non-pyrophilous behavior (Bohbot \& Dickens 2012; Holighaus 2012). Moreover, some of these VOCs are known to be released by other sources such as guaiacol (Holighaus 2006), hydroxyacetone (Ômura et al., 2000), and 5methylfurfural (Becher et al., 2010, for more detail see chapter 6.2). Therefore, not all insects which can perceive these single burnt wood VOCs are necessarily pyrophilous. This is also the reason why we used the traps baited with a mixture of fire-specific VOCs. In order to conclude the behavior of insects in burnt habitats, the sensory capabilities of potentially pyrophilous 
insects should be investigated by EAG recordings and the presence of IR receptors should be confirmed.

\subsection{Is infrared radiation a cue for pyrophilous insects to find burnt habitats? (Chapter}

\section{4)}

Infrared receptors are found in some pyrophilous insects. It has been speculated that receptors are used for detecting forest fires. The pyrophilous bug A. candidatus approaches open flames (own observation) and possesses IR receptors (chapter 5). There is strong evidence that buprestid beetles of the genus Melanophila approach forest fires (Champion 1909; Nicholson 1919; Linsley 1943; Evans 1962, 1964; Apel 1988, 1989). These beetles perceive IR radiation with their thoracic IR receptors (Evans 1964; Schmitz et al., 2000). The Australian fire beetle M. atrata is known to detect fires from far distances (Poulton 1915; Schmitz et al., 2002). This species has two pairs of IR organs on the ventrolateral sides of the abdomen (Schmitz et al., 2000). However, IR receptors are obviously only used for the orientation on freshly burnt areas (Hinz et al. 2018). The "Little Ash Beetle" A. nigricans (family Acanthocnemidae) approaches forest fires (Champion 1922). Acanthocnemus nigricans possesses IR receptors on the prothorax (Schmitz et al., 2002). Several species of flat bugs (Heteroptera: Aradidae) are found frequently at burnt sites (Hjältén et al., 2006) whereas Aradus species are often attracted by the open fire, hot ashes or smoke, such as A. albicornis and A. lugubris (Wikars 1997). IR receptors have been found in A. albicornis (Schmitz et al., 2008), and also in A. lugubris, A. flavicornis, and A. fuscicornis (Schmitz et al., 2010).

On the other hand, several insect species were attracted only to traps having an IR source in this study (chapter 4). They may use only IR receptors to detect fires (Schmitz et al., 2002; Kreiss et al., 2005, 2007; Heisswolf et al., 2007; Paczkowski et al., 2014). Therefore, IR may play an important role for these insect species to find forest fires. If IR receptors are considered to have evolved only in the context of forest fires, we conclude that insects attracted by IR traps alone can be considered as pyrophilous. However, random landing, while sensing the warm surface of the trap might also contribute to the results and should be considered as an alternative explanation for insects that might not be pyrophilous but prefer warm surfaces. A search for efficient thermoreceptors, therefore, may be reasonable. 


\subsection{Attraction of insects in recently burnt habitats to VOCs, infrared stimuli or both stimuli}

For the first time, the preference of insects in recently burnt habitats for different fire-relevant stimuli was tested (chapters 4 and 5). Compared to control traps and exposure of all types of traps in unburnt forest areas, our numerous trap catches from recently burnt habitats demonstrate that our newly developed traps emitting either IR radiation, fire-specific VOCs or a combination of both, effectively attracted insects likely having a pyrophilous lifestyle. In detail, differences in their attraction according to different fire-relevant stimuli became apparent. This suggests that IR radiation alone might be capable of attracting pyrophilous insects, while fire-specific VOCs or their combination with IR radiation seems to play an important role for their attraction to burnt areas. Similarly, the number of insect species occurring in VOC traps alone exceeds that of those that were found in IR traps only. This might be also due to a repellent effect of the IR radiation to certain species that are otherwise attracted to fire-specific VOCs. Due to a very limited number of custom-made traps capable of emitting IR radiation, the results should be interpreted cautiously. However, our findings might indicate that certain species of pyrophilous insects rely either on IR or on VOC stimuli, but might not be susceptible to both stimuli, while the majority combines both information. There is also no clear tendency that IR radiation increases or decreases the attractivity of VOCs alone.

In the special case of A. candidatus (chapter 5), no clear tendency preference towards VOCs or IR stimuli has been found, probably due to low catch numbers. More detailed explanations are presented in chapter 6.1 .

\subsection{Is multimodal sensing important for the behavior of pyrophilous insects? Hints from}

\section{A. candidatus (chapter 5)}

It has been postulated that $A$. candidatus uses different cues (olfactory and IR) for fire and heat detection (chapter 5). As some pyrophilous insects typically show strong preferences towards open flames, A. candidatus also shows an attraction response to both burnt wood VOCs and IR radiation. The number of $A$. candidatus individuals caught by traps with a combined stimulus was slightly higher than in traps baited only with VOCs or IR radiation. A possible explanation may be that $A$. candidatus integrates the information of IR receptors and fire-specific olfactory receptors, resulting in a stronger behavioral response. However, although less A. candidatus were trapped in VOC traps than in the traps combining IR and VOCs, it still might be true that A. candidatus uses its IR receptors for a safe landing near hot spots (Schmitz et al., 2008, 2010). At least the presence of IR radiation as provided in our traps does not reduce the attractivity of 
the fire-specific VOCs. Thus, the testability of exact landing behavior might not be possible in our traps and needs more sophisticated behavioral studies and observations. In contrast, $A$. nigricans (chapter 3) has been found to show a strong preference for approaching smoldering logs (Champion 1922) and possesses IR receptors on the prothorax (Schmitz et al., 2002). However, these pyrophilous insect species were not attracted by our traps. There were a few insect species attracted only by the traps combining IR and VOCs, but not by other traps (chapter 4). This might disprove the idea that traps combining IR and VOCs would also attract those species found in either VOC traps or IR traps. Further studies should be conducted to clarify this situation.

\subsection{Conclusion}

This work has demonstrated the presence of two pyrophilous insect species in Vietnam: Aradus candidatus and Acanthocnemus nigricans. Associated with the diversity of burnt wood VOCs, different insect species were found in burnt habitats, including herbivores, carnivores and fungivores. It has been emphasized that there are various insect species which colonize recently burnt habitats in Vietnam. However, they are not necessarily pyrophilous. Similarly, the confirmed attraction of insects to burnt wood VOCs (chapter 3 and 4) could not let us finally conclude about a fire-loving biology of these species, because some of the fire-specific VOCs tested in our study are also emitted by other sources (Bruce et al., 2005; Schoonhoven et al., 2005; Kües \& Navarro-Gonzales 2009). Moreover, certain fire-specific volatiles (e.g., guaiacol) are also perceived by other insect species which do not show pyrophilous behavior (Bohbot \& Dickens 2012; Holighaus 2012). Therefore, the combination of both VOCs and IR provided the strongest evidence for a pyrophilous biology in some insect species. However, it should be considered that the attraction responses towards burnt wood VOCs and IR radiation observed in pyrophilous insects vary between insect species. They are found in the case of $A$. candidatus and the well-known pyrophilous beetle A. nigricans. The pyrophilous flat bug species showed a strongly pyrophilous behavior, appearing immediately at burnt sites with a significant attraction response towards a mixture of burnt wood VOCs and IR radiation, as well as by a combination of both. In addition, IR receptors of $A$. candidatus were found on the thorax. In contrast, A. nigricans is attracted to smoldering logs and possesses IR receptors (Schmitz et al., 2002), showing EAG responses to burnt wood VOCs (Paczkowski et al., 2013). However, no individual of $A$. nigricans was attracted by any of our traps.

This pioneer study on the adaptation of pyrophilous insects in burnt habitats in Vietnam brought out manifold results about the relevance of odor signals, IR reception, and attraction behavior 
of pyrophilous insects of Vietnam. Consequently, new trendsetting ideas on the biology and ecological function of pyrophilous insects and other insect species recolonizing burnt habitats as well as new points of view regarding the impact of different forest fire management regimes on pyrophilous species could follow. These ideas are to be addressed in future research. 


\subsection{References}

Apel, K.H. (1988). Befallsverteilung von Melunophila acuminata DEG., Phaenops cyanea F. und $\mathrm{Ph}$. formnneki JACOB (Col., Buprestidae) auf Waldbrandflachen. Beiträge für Forstwirtschaft, 22:45-48.

Apel, K.H. (1989). Zur Verbreitung von Melunophilu acuminata DEG. (Col., Buprestidae). Entomol. Nach. Ber. 33, 278-280.

Becher, P. G., Bengtsson, M., Hansson, B. S. and Witzgall, P. (2010). Flying the fly: longrange flight behavior of Drosophila melanogaster to attractive odors. Journal of Chemical Ecology, 36(6): 599-607.

Beck, J. J., Mahoney, N. E., Cook, D. and Gee, W. S. (2012). Generation of the volatile spiroketals conophthorin and chalcogran by fungal spores on polyunsaturated fatty acids common to almonds and pistachios. Journal of Agricultural and Food Chemistry, 60(48): 11869-11876.

Bohbot, J. D. and Dickens, J. C. (2012). Odorant receptor modulation: Ternary paradigm for mode of action of insect repellents. Neuropharmacology, 62(5-6): 2086-2095.

Bruce, T. J. A., Wadhams, L. J. and Woodcock, C. M. (2005). Insect host location: a volatile situation. Trends in Plant Science, 10(6): 269-274.

Champion, G. C. (1909). A buprestid and other Coleoptera on pine injured by "heath fires" in N.W. Surrey. Entomologist's Monthly Magazine, 45, 247-250.

Champion, G. (1922). The Geographical Distribution and Synonymy of the Dasytid-Beetle Acanthocnemus nigricans Hope (=ciliatus Perris). Entomologist's Monthly Magazine, 58(4): 77-79.

Cocciufa, C., Gerth, W., Luiselli, L., De Zan, L. R., Cerretti, P. and Carpaneto, G. M (2014). Survey of saproxylic beetle assemblage sat different forest plots in central Italy. Bulletin of Insectology, 67(2): 295-306.

Evans, W. G. (1962). Notes on the biology and dispersal of Melanophilu (Coleoptera: Buprestidae). Pan-Pacific Entomology, 38: 59-62.

Evans, G. (1964). Infra-red receptors in Melanophila acuminata DeGeer. Nature, 202: 211.

Geiser, M. (2016). An update on the distribution of the pyrophilous beetle Acanthocnemus nigricans (Hope, 1845) (Coleoptera: Cleroidea: Acanthocnemidae), including new records from Laos. Entomologica Basiliensia et Collectionis Frey, 35: 429-432.

Heisswolf, A., Gabler, D., Obermaier, E. and Muller, C. (2007). Olfactory versus contact cues in host plant recognition of a monophagous chrysomelid beetle. Journal of Insect Behavior, 20: 247-266.

Hinz, M., Klein, A., Schmitz, A. and Schmitz, H. (2018). The impact of infrared radiation in flight control in the Australian "firebeetle" Merimna atrata. PLoS One, 13(2): e0192865. 
Hjältén, J., Atlegrim, O., Sandström, F., Pettersson, R. and Rexstad, E.A. (2006). Occurrence of flat bugs (Heteroptera: Aradidae) in burned and unburned forests. Entomologica Fennica, 17: 130-135.

Holighaus, G. and Schütz, S. (2006). Odours of wood decay as semiochemicals for Trypodendron domesticum L. (Col., Scolytidae). Mitteilungen Deutsche Gesellschaft für allgemeine und angewandte Entomologie, 15: 161-165.

Holighaus, G. (2012). Odour signals relevant to beetles in deadwood habitats. PhD Thesis. Faculty of Forest Sciences and Forest Ecology. University of Göttingen, Germany.

Hyttinen, M., Masalin-Weijo, M., Kalliokoski, P. and Pasanen, P. (2010). Comparison of VOC emissions between air-dried and heat-treated Norway spruce (Picea abies), Scots pine (Pinus sylvestris) and European aspen (Populus tremula) wood. Atmospheric Environment, 44(38): 5028-5033.

Kollmann, F. (1982). Technologie des Holzes und der Holzwerkstoffe, Anatomie und Pathologie, Chemie, Physik, Elastizität und Festigkeit. Springer, Berlin, Germany, 1051 pp.

Kreiss, E.-J., Schmitz, A. and Schmitz, H. (2005). Morphology of the prothoracic discs and associated sensilla of Acanthocnemus nigricans (Coleoptera, Acanthocnemidae). Arthropod Structure and Development, 34(4): 419-428.

Kreiss, E., Schmitz, H. and Gebhardt, M. (2007). Electrophysiological characterization of the infrared organ of the Australian "little ash beetle" Acanthocnemus nigricans (Coleoptera, Acanthocnemidae). Journal of Comparative Physiology, 193(7): 729-739.

Kües, U. and Navarro-González, M. (2009). Communication of Fungi on Individual, Species, Kingdom, and Above Kingdom Levels. Pp. 79-106 in: Anke, T., and Weber, D. (eds): The Mycota XV. Physiology and genetics. Springer, Berlin Heidelberg New York.

Linsley, G. E. (1943). Attraction of Melanophila beetles by fire and smoke. Journal of Economic Entomology, 36(2): 341-342.

Nicholson, G. W. (1919). Melanophila acuminata De Geer at a fire in June. Entomologist's Monthly Magazine, 55: 156-157.

Ômura, H., Honda, K. and Hayashi, N. (2000). Identification of feeding attractants in oak sap for adults of two nymphalid butterflies, Kaniska canace and Vanessa indica. Physiological Entomology, 25(3): 281-287.

Paczkowski, S., Paczkowska, M., Dippel, S., Schulze, N., Schütz, S., Sauerwald, T., et al. (2013). The olfaction of a fire beetle leads to new concepts for early fire warning systems. Sensors and Actuators, B: Chemical, 183: 273-282.

Paczkowski, S., Paczkowska, M., Dippel, S., Flematti, G. and Schütz, S. (2014). Volatile Combustion Products of Wood Attract Acanthocnemus nigricans (Coleoptera: Acanthocnemidae). Journal of Insect Behaviour, 27(2): 228-238. 
Pelosi, P. and Maida, R. (1995). Odorant-binding proteins in insects. Comparative Biochemistry and Physiology B-Biochemistry \& Molecular Biology, 111(3): 503-514.

Poulton, E. B. (1915). The habits of the Australian buprestid "fire beetle," Merimna atrata Lap., et Gory. Transactions of the Entomological Society of London. Part 1: iii-iV.

Reyes-Vidal, Y. and De la Torre, M. (2009). Emission, perception, and behavioral responses of entomopathogenic nematodes to semiochemicals. Nematropica, 39(2): 213-223.

Schmitz, H., Bleckmann, H. and Schmitz, A. (2000). A new type of infrared organ in the Australian "fire-beetle" Merimna atrata (Coleoptera: Buprestidae). Naturwissenschaften, 87(12): 542-545.

Schmitz, H., Schmitz, A., Trenner, S. and Bleckmann, H. (2002). A new type of insect infrared organ of low thermal mass. Naturwissenschaften, 89(5): 226-229.

Schmitz, A., Sehrbrock, A. and Schmitz, H. (2007). The analysis of the mechanosensory origin of the infrared sensilla in Melanophila acuminata (Coeloptera; Buprestidae) adduces new insight into the transduction mechanism. Arthropod Structure and Development, 36(3), 291-303.

Schmitz, A., Gebhardt, M. and Schmitz, H. (2008). Microfluidic photomechanic infrared receptors in a pyrophilous flat bug. Naturwissenschaften, 95(5): 455-60.

Schmitz, A., Schätzel, H. and Schmitz, M. (2010). Distribution and functional morphology of photomechanic infrared sensilla in flat bugs of the genus Aradus (Heteroptera, Aradidae). Arthropod structure \& development 39(1): 17-25.

Schoonhoven, L. M., Van Loon, J. J. A. and Dicke, M. (2005). Insect-plant biology. Oxford University Press, Oxford, United Kingdom, 421 pp.

Schütz, S., Weißbecker, B., Hummel, H. E., Apel, K.-H., Schmitz, H. and Bleckmann, H. (1999). Insect antenna as a smoke detector. Nature, 398: 298-299.

Verheggen, F. J., Arnaud, L., Bartram, S., Gohy, M. and Haubruge, E. (2008). Aphid and plant volatiles induce oviposition in an aphidophagous hoverfly. Journal of Chemical Ecology. 34(3): 301-307.

Wikars, L.O. (1997). Effects of forest fire and the ecology of fire-adapted insects. Comprehensive Summaries of Uppsala Dissertations from the Faculty of Science and Technology 272. Acta Universitatis Upsaliensis, Uppsala, Sweden, 272 pp. 


\section{Publications by T. P. Hoang}

\section{Refereed publication:}

Hoang, T. P., and Schütz, S. (2015). Pyrophilous Insects in Vietnam Central Highlands. Mitteilungen Deutsche Gesellschaft für allgemeine und angewandte Entomologie, 20: 133138.

\section{Manuscripts prepared for pulication:}

Hoang, T. P., Schmitz, H., Holighaus, G. (Manuscript). Do volatiles released upon heating of different species of Vietnamese woody plants attract pyrophilous insects? $21 \mathrm{pp}$.

Hoang, T. P., Holighaus, G., and Schmitz, H. (Manuscript). Pyrophilous insects response to different stimuli. $14 \mathrm{pp}$.

Hoang, T. P., Holighaus, G., and Schmitz, H. (Manuscript). Behavioral and sensory adaptations of the flat bug Aradus candidatus to post-fire habitats in Vietnam. 19pp. 


\section{Annex}

Table S1: Emission rates $\left(\mu \mathrm{g} / \mathrm{g}^{*} \mathrm{~s}\right)$ in furfural-equivalents (furanes, pyrans, esters, ketones, anhydrosugars), guaiacol-equivalents (phenols, guaiacols, syringols), and $\alpha$-humulene-equivalents (naphthalenes, terpenoids). The values of the emission rate are displayed in the following order: minima, lower quartile, median, upper quartile, minima, and maxima. A minimum above $0(\mu \mathrm{g} / \mathrm{g} * \mathrm{~s})$ shows a reliable emission of the compound at this temperature step.

The statistical significantly different results were obtained in columm 1 :

\# $\quad$ Significant difference between WSP1 and WSP2 at $(\downarrow) 250^{\circ} \mathrm{C}$ or at $(\uparrow) 300^{\circ} \mathrm{C}$ or at both temperatures $(\downarrow \uparrow)$;

$\dagger \quad$ Significant difference between WSP1 and WSP3 at $(\downarrow) 250^{\circ} \mathrm{C}$ or at $(\uparrow) 300^{\circ} \mathrm{C}$ or at both temperatures $(\downarrow \uparrow)$;

$\varnothing \quad$ Significant difference between WSP1 and WSP4 at $(\downarrow) 250^{\circ} \mathrm{C}$ or at $(\uparrow) 300^{\circ} \mathrm{C}$ or at both temperatures $(\downarrow \uparrow)$;

$¥ \quad$ Significant difference between WSP2 and WSP3 at $(\downarrow) 250^{\circ} \mathrm{C}$ or at $(\uparrow) 300^{\circ} \mathrm{C}$ or at both temperatures $(\downarrow \uparrow)$;

$\notin \quad$ Significant difference between WSP2 and WSP 4 at $(\downarrow) 250^{\circ} \mathrm{C}$ or at $(\uparrow) 300^{\circ} \mathrm{C}$ or at both temperatures $(\downarrow \uparrow)$;

a Significant difference between WSP3 and WSP 4 at $(\downarrow) 250^{\circ} \mathrm{C}$ or at $(\uparrow) 300^{\circ} \mathrm{C}$ or at both temperatures $(\downarrow \uparrow)$.

Each volatile was characterized by three primary constituents: polysaccharide, lignin, and extractive. ST= sesquiterpene.

a,b,c. Identification confirmed by a. Co-elution of authentic standard, b. LRI /HP-5MS +LRI /INNOWAX+ mass spectrum library, c. LRI and/or Mass spectrum library.

\begin{tabular}{|c|c|c|c|c|c|c|c|c|c|c|c|c|c|c|c|c|c|}
\hline \multirow{3}{*}{ ID } & \multirow{3}{*}{ Compound } & \multirow{3}{*}{ 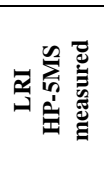 } & \multirow{3}{*}{$\begin{array}{l}\text { Functional } \\
\text { group }\end{array}$} & \multirow{3}{*}{ 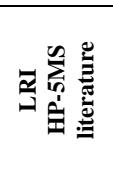 } & \multirow{3}{*}{ 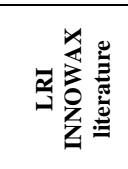 } & \multicolumn{8}{|c|}{ Emission rates $(\mu \mathrm{g} / \mathrm{g} * \mathrm{~s}))$} & \multirow{3}{*}{ Products of } & \multicolumn{3}{|c|}{$\begin{array}{c}\text { Authentic standard } \\
\text { factors }\end{array}$} \\
\hline & & & & & & \multicolumn{4}{|c|}{$250^{\circ} \mathrm{C}$} & \multicolumn{4}{|c|}{$300^{\circ} \mathrm{C}$} & & \multirow{2}{*}{$\begin{array}{l}\text { CAS } \\
\text { No. }\end{array}$} & \multirow{2}{*}{$\begin{array}{l}\text { Compa- } \\
\text { ny }\end{array}$} & \multirow{2}{*}{$\begin{array}{l}\text { Pu- } \\
\text { rity }\end{array}$} \\
\hline & & & & & & WSP1 & WSP2 & WSP3 & WSP4 & WSP1 & WSP2 & WSP3 & WSP4 & & & & \\
\hline $\begin{array}{l}\mathbf{C 1}^{\mathbf{b}} \\
\# \dagger{ }^{\prime}{ }^{-}\end{array}$ & hydroxyacetone & $<800$ & Ketone & $<800$ & & $\begin{array}{ll}0.1, & 0.2, \\
0.2, & 0.2, \\
0.2\end{array}$ & $\begin{array}{l}0.2, \\
0.2, \\
0.2, \\
0.3,0.3\end{array}$ & $\begin{array}{l}0.1, \\
0.1, \\
0.1, \\
0.1,0.1\end{array}$ & $\begin{array}{l}0.1, \\
0.1, \\
0.1, \\
0.1, \\
0.1\end{array}$ & $\begin{array}{l}0.2,0.2, \\
0.3,0.9, \\
1.2\end{array}$ & $\begin{array}{l}0.5, \\
0.5, \\
2.2, \\
2.5,5.1\end{array}$ & $\begin{array}{l}5.4, \\
6.5, \\
7.7, \\
8.9, \\
11.1\end{array}$ & $\begin{array}{l}4.8, \\
5.9, \\
8.3, \\
8.4,9.5\end{array}$ & $\begin{array}{l}\text { Cellulose }+ \\
\text { Hemi-cellulose }\end{array}$ & & & \\
\hline $\begin{array}{l}\mathbf{C 2}^{\mathbf{a}} \\
\uparrow \uparrow\end{array}$ & 3-furaldehyde & 838 & Furane & $\begin{array}{l}837 * \\
(801- \\
837)\end{array}$ & $1441^{*}$ & $\begin{array}{l}0,0,0 \\
0.1,0.2\end{array}$ & $\begin{array}{l}0,0,0, \\
0.1,0.2\end{array}$ & 0 & 0 & $\begin{array}{l}0,0,0 \\
0.1,0.3\end{array}$ & 0.1 & $\begin{array}{l}0,1.3, \\
2.4, \\
2.4,7.2\end{array}$ & 0 & Pentosan & $\begin{array}{l}498- \\
60-2\end{array}$ & Aldrich & $97 \%$ \\
\hline $\begin{array}{l}\mathbf{C 3}^{\mathbf{a}} \\
\emptyset \notin \downarrow\end{array}$ & furfural & 853 & Furane & $860^{* * * *}$ & $1482 * * *$ & $\begin{array}{l}22,30.1 \\
30.8 \\
34.3 \\
42.8\end{array}$ & $\begin{array}{l}36.3, \\
36.5, \\
46.5, \\
55.7, \\
71.6\end{array}$ & $\begin{array}{l}8.5,15, \\
26.8, \\
44.2, \\
62.3\end{array}$ & $\begin{array}{l}308.6, \\
318, \\
373.6, \\
470.4, \\
841.1\end{array}$ & $\begin{array}{l}0.1,6.1, \\
14.9, \\
27.7, \\
37.2\end{array}$ & $\begin{array}{l}0.3, \\
0.3, \\
30.7 \\
37.3, \\
72.3\end{array}$ & $\begin{array}{l}12.1, \\
22.2, \\
31.1, \\
36.7, \\
49.8\end{array}$ & $\begin{array}{l}218, \\
368.4, \\
408.7, \\
427.4 \\
961\end{array}$ & Pentosan & $\begin{array}{l}98-01- \\
1\end{array}$ & Acros & $99 \%$ \\
\hline $\begin{array}{l}\text { C4 }^{\text {a }} \\
\# ¥ \downarrow \\
\dagger ¥ \uparrow\end{array}$ & 2-furanmethanol & 873 & Furane & $877^{* * * *}$ & 1564 & $\begin{array}{l}0.8,1.4, \\
1.6,1.6, \\
2.7\end{array}$ & $\begin{array}{l}4.2, \\
4.4, \\
6.1, \\
25.7, \\
44.8\end{array}$ & 0 & $\begin{array}{l}128.4, \\
217, \\
399.3, \\
444.9, \\
852.3\end{array}$ & $\begin{array}{l}0.5,1.3 \\
1.4,1.5 \\
2.8\end{array}$ & $\begin{array}{l}9.7 \\
14.1, \\
19.1, \\
27,38 \\
\end{array}$ & 0 & $\begin{array}{l}0,44.5, \\
63.4, \\
214, \\
567.9\end{array}$ & Cellulose & $\begin{array}{l}98-00- \\
0\end{array}$ & Merck & $99 \%$ \\
\hline
\end{tabular}




\begin{tabular}{|c|c|c|c|c|c|c|c|c|c|c|c|c|c|c|c|c|c|}
\hline \multirow{3}{*}{ ID } & \multirow{3}{*}{ Compound } & \multirow{3}{*}{ 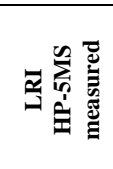 } & \multirow{3}{*}{$\begin{array}{l}\text { Functional } \\
\text { group }\end{array}$} & \multirow{3}{*}{ 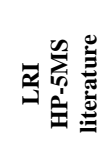 } & \multirow{3}{*}{ 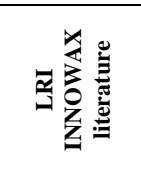 } & \multicolumn{8}{|c|}{ Emission rates $(\mu \mathrm{g} / \mathrm{gs}))$} & \multirow{3}{*}{ Products of } & \multicolumn{3}{|c|}{$\begin{array}{c}\text { Authentic standard } \\
\text { factors }\end{array}$} \\
\hline & & & & & & \multicolumn{4}{|c|}{$250^{\circ} \mathrm{C}$} & \multicolumn{4}{|c|}{$300^{\circ} \mathrm{C}$} & & \multirow{2}{*}{$\begin{array}{l}\text { CAS } \\
\text { No. }\end{array}$} & \multirow{2}{*}{$\underset{\text { ny }}{\text { Compa- }}$} & \multirow{2}{*}{$\begin{array}{l}\text { Pu- } \\
\text { rity }\end{array}$} \\
\hline & & & & & & WSP1 & WSP2 & WSP3 & WSP4 & WSP1 & WSP2 & WSP3 & WSP4 & & & & \\
\hline $\begin{array}{l}\text { C5 } \\
a \downarrow\end{array}$ & $\begin{array}{l}\text { 1-(acetyloxy)-2- } \\
\text { propanone }\end{array}$ & 887 & Ester & $\begin{array}{l}867 * * \\
(821- \\
867)\end{array}$ & $\begin{array}{l}1476 \text { ** } \\
(1464- \\
1484)\end{array}$ & 0 & $\begin{array}{l}8.2, \\
8.6, \\
13.4, \\
24.2, \\
67\end{array}$ & 0 & 0 & 0 & $\begin{array}{l}0, \quad 0, \\
29.5, \\
48.6, \\
116\end{array}$ & 0 & 0 & Cellulose & $\begin{array}{l}592- \\
20-1\end{array}$ & Aldrich & $98 \%$ \\
\hline $\begin{array}{l}\mathbf{C 6}^{\mathbf{b}} \\
\not \downarrow \downarrow\end{array}$ & $\begin{array}{l}\text { 2-cyclopentene-1,4- } \\
\text { dione }\end{array}$ & 898 & Ketone & $\begin{array}{l}882 * * \\
(836- \\
911)\end{array}$ & $\begin{array}{l}1191 * * \\
(1535- \\
1605)\end{array}$ & $\begin{array}{l}0, \quad 2.7, \\
4.8, \quad 9, \\
24.6\end{array}$ & $\begin{array}{l}7.5, \\
16.4, \\
17.7, \\
18.4, \\
47.3\end{array}$ & $\begin{array}{l}3.9, \\
10.4, \\
10.9, \\
19.3, \\
61.9\end{array}$ & $\begin{array}{l}0,1.3, \\
2.8, \\
5.6, \\
6.5\end{array}$ & $\begin{array}{l}0, \quad 9.5, \\
16.3, \\
20.8, \\
24.6\end{array}$ & $\begin{array}{l}0,1.2, \\
62.4, \\
78, \\
210.6\end{array}$ & $\begin{array}{l}11.2, \\
12.5, \\
18.7, \\
22.3, \\
116.4\end{array}$ & $\begin{array}{l}1.9, \\
7.5, \\
7.7, \\
9.9, \\
10.7\end{array}$ & Cellulose & & & \\
\hline $\mathbf{C 7}^{\mathrm{b}}$ & $\begin{array}{l}\text { 1-(2-furanyl)- } \\
\text { ethanone }\end{array}$ & 924 & Furane & $\begin{array}{l}892^{*} \\
(881- \\
929)\end{array}$ & $\begin{array}{l}1475^{*} \\
(1475- \\
1538)\end{array}$ & $\begin{array}{ll}0, & 2.9 \\
33, & 58 \\
93 & \end{array}$ & $\begin{array}{l}26.6, \\
30.7, \\
51.3, \\
62.8, \\
204.3\end{array}$ & $\begin{array}{l}24.5, \\
58.7, \\
59.8, \\
97.9, \\
163.1\end{array}$ & $\begin{array}{l}9.6, \\
12.5, \\
29.1, \\
35.5, \\
58.8\end{array}$ & $\begin{array}{l}19.3, \\
25.8, \\
34.4, \\
59.1,93\end{array}$ & $\begin{array}{l}5.4, \\
6.2, \\
110.3, \\
190.9 \\
401.1\end{array}$ & $\begin{array}{l}47.5, \\
64.4, \\
170.5, \\
195.5, \\
206.2\end{array}$ & $\begin{array}{l}27.4, \\
96.9, \\
123, \\
143.1, \\
250.9\end{array}$ & & & & \\
\hline $\begin{array}{l}\mathbf{C 8}^{\mathbf{a}} \\
\dagger ¥ \downarrow \uparrow\end{array}$ & 2(5H)-furanone & 927 & Furane & $924 * * *$ & 1602 **** & $\begin{array}{l}1.7,3.7 \\
33,46.4 \\
118.1\end{array}$ & $\begin{array}{l}8.2,11, \\
12.1, \\
15.4 \\
32\end{array}$ & 0 & $\begin{array}{l}1.1, \\
1.5, \\
2.3, \\
3.9, \\
6.1\end{array}$ & 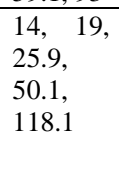 & $\begin{array}{l}7.6, \\
10.1, \\
20.1, \\
21.9, \\
32.5\end{array}$ & 0 & $\begin{array}{l}1.8,2, \\
7.1, \\
7.4, \\
15.7\end{array}$ & Glucosan & $\begin{array}{l}497- \\
23-4\end{array}$ & Aldrich & $98 \%$ \\
\hline $\begin{array}{l}\text { C9 }^{\mathbf{a}} \\
\# ¥ \not \uparrow \downarrow\end{array}$ & butyrolactone & 933 & Furane & $\begin{array}{l}928 * * \\
(861- \\
928)\end{array}$ & $\begin{array}{l}(1592- \\
1650)\end{array} * *$ & 0 & $\begin{array}{l}30.6, \\
32.5, \\
39.1, \\
44.9, \\
49\end{array}$ & 0 & & 0 & $\begin{array}{l}33.4, \\
45.7, \\
46.7, \\
84, \\
112.3\end{array}$ & 0 & 0 & $\begin{array}{l}\text { Cellulose }+ \\
\text { Hemi-cellulose }\end{array}$ & $\begin{array}{l}96-48- \\
0\end{array}$ & Fluka & $99 \%$ \\
\hline $\begin{array}{l}\mathbf{C 1 0}^{\mathbf{b}} \\
\# \dagger \varnothing \downarrow\end{array}$ & 2-cyclohexen-1-one & 942 & Pyran & $\begin{array}{l}927^{*} \\
(910- \\
957)\end{array}$ & $1838^{* * *}$ & $\begin{array}{ll}0.7, & 0.9, \\
2.1, & 6, \\
7.6 & \\
\end{array}$ & 0 & 0 & 0 & $\begin{array}{l}0,0,1.2 \\
4.8,7.6\end{array}$ & 0 & 0 & 0 & & & & \\
\hline $\begin{array}{l}\text { C11'a } \\
\# \notin \downarrow \downarrow \\
\alpha \uparrow\end{array}$ & $\begin{array}{l}\text { 2H-2-one- } \\
\text { Pyran,5,6 dihydro }\end{array}$ & & Pyran & & & 0 & $\begin{array}{l}0,2.2, \\
2.8, \\
3.5,5.6\end{array}$ & $\begin{array}{l}0, \quad 0, \\
0.7, \\
1.5,6\end{array}$ & 0 & 0 & $\begin{array}{l}0, \quad 0, \\
4.3, \\
10.5, \\
12.5\end{array}$ & $\begin{array}{l}4.8, \\
5.4, \\
5.7, \\
14.1, \\
36.3 \\
\end{array}$ & 0 & & & & \\
\hline $\begin{array}{l}\mathbf{C 1 2}^{\mathbf{a}} \\
\# \dagger \varnothing \uparrow\end{array}$ & $\begin{array}{l}\text { 3-methyl-2,5- } \\
\text { furandione }\end{array}$ & & Furane & & & $\begin{array}{l}0,0,0 \\
3.9,4.7\end{array}$ & 0 & 0 & 0 & $\begin{array}{l}0, \quad 0.5, \\
3.3,4.7, \\
13.2\end{array}$ & 0 & 0 & 0 & & & & \\
\hline $\begin{array}{l}\mathbf{C 1 3}^{\mathrm{a}} \\
\# \dagger \varnothing \downarrow\end{array}$ & $\begin{array}{l}\text { 2-hydroxy-1- } \\
\text { methoxy-ethylfuran }\end{array}$ & & Furane & & & $\begin{array}{l}0, \quad 5.4, \\
76.9, \\
236, \\
4606.3\end{array}$ & 0 & 0 & 0 & $\begin{array}{l}0,0,4, \\
28.5, \\
4606.3\end{array}$ & 0 & 0 & 0 & & & & \\
\hline
\end{tabular}




\begin{tabular}{|c|c|c|c|c|c|c|c|c|c|c|c|c|c|c|c|c|c|}
\hline \multirow{3}{*}{ ID } & \multirow{3}{*}{ Compound } & \multirow{3}{*}{ 施离 } & \multirow{3}{*}{$\begin{array}{l}\text { Functional } \\
\text { group }\end{array}$} & \multirow{3}{*}{ 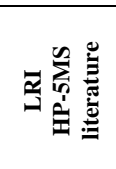 } & \multirow{3}{*}{ 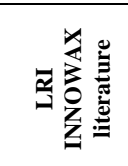 } & \multicolumn{8}{|c|}{ Emission rates $(\mu \mathrm{g} / \mathrm{gs}))$} & \multirow{3}{*}{ Products of } & \multicolumn{3}{|c|}{$\begin{array}{c}\text { Authentic standard } \\
\text { factors }\end{array}$} \\
\hline & & & & & & \multicolumn{4}{|c|}{$250^{\circ} \mathrm{C}$} & \multicolumn{4}{|c|}{$\mathbf{3 0 0}^{\circ} \mathrm{C}$} & & \multirow{2}{*}{$\begin{array}{l}\text { CAS } \\
\text { No. }\end{array}$} & \multirow{2}{*}{$\underset{\text { ny }}{\text { Compa- }}$} & \multirow{2}{*}{$\begin{array}{l}\text { Pu- } \\
\text { rity }\end{array}$} \\
\hline & & & & & & WSP1 & WSP2 & WSP3 & WSP4 & WSP1 & WSP2 & WSP3 & WSP4 & & & & \\
\hline $\begin{array}{l}\text { C14 }^{\mathbf{a}} \\
\# \dagger \varnothing^{\uparrow}\end{array}$ & $\begin{array}{l}\text { phenethyl ester } \\
\text { acetic acid }\end{array}$ & & acid & & & $\begin{array}{l}0,0,0.6 \\
0.7,2.8\end{array}$ & 0 & 0 & 0 & $\begin{array}{ll}0, & 0.3, \\
1.6, & 2.4, \\
3.2 & \end{array}$ & 0 & 0 & 0 & & & & \\
\hline $\begin{array}{l}\text { C15 }^{\text {a }} \\
\phi a \downarrow \uparrow \\
\dagger \downarrow\end{array}$ & 5-methylfurfural & 972 & Furane & $985^{* * * *}$ & $1591 * * *$ & $\begin{array}{l}0.5,0.5, \\
0.5,0.5, \\
0.5\end{array}$ & $\begin{array}{l}7.6, \\
8.1, \\
8.3, \\
9.2, \\
10.6\end{array}$ & $\begin{array}{l}1,1.5, \\
1.5, \quad 4, \\
10.8\end{array}$ & $\begin{array}{l}0.1, \\
0.2, \\
0.3, \\
0.3, \\
0.7\end{array}$ & $\begin{array}{l}0.5,0.7, \\
0.7,0.7, \\
0.7\end{array}$ & $\begin{array}{l}13.1, \\
13.2, \\
13.3, \\
13.5, \\
13.9\end{array}$ & $\begin{array}{l}1.9, \\
2.3, \\
2.9, \\
3.4, \\
14.5\end{array}$ & $\begin{array}{l}0.4, \\
0.8, \\
1.2, \\
1.6,4.1 \\
\end{array}$ & $\begin{array}{ll}\text { Cellulose } & + \\
\text { Hemi- } & \\
\text { cellulose } & \end{array}$ & $\begin{array}{l}620- \\
02-0\end{array}$ & Acros & $98 \%$ \\
\hline $\begin{array}{l}\mathbf{C 1 6}^{\mathbf{b}} \\
\dagger \varnothing ¥ \notin \square \downarrow \\
¥ \notin \uparrow\end{array}$ & $\begin{array}{l}\text { 3-methyl-5- } \\
\text { methyliden-2(5H)- } \\
\text { furanone }\end{array}$ & 984 & Furane & $989 *$ & $1718^{*}$ & $\begin{array}{l}0, \quad 0.1, \\
0.1,0.1, \\
0.3\end{array}$ & $\begin{array}{l}0, \quad 0.3 \\
0.4, \\
0.5,0.7\end{array}$ & 0 & 0 & $\begin{array}{l}0.1,0.1, \\
0.1,0.2, \\
0.4\end{array}$ & $\begin{array}{ll}0, & 0, \\
0.9, & \\
2.3, & 2.6\end{array}$ & 0 & 0 & & & & \\
\hline $\begin{array}{l}\text { C17 }^{\mathbf{a}} \\
\# \notin a \downarrow \\
\dagger \varnothing ¥ \varnothing \uparrow\end{array}$ & phenol & 994 & Phenol & $\begin{array}{l}981 * * \\
(943- \\
1002)\end{array}$ & $\begin{array}{l}2008 * * \\
(1947- \\
2009)\end{array}$ & $\begin{array}{l}0,0,0 \\
0,1.8\end{array}$ & $\begin{array}{l}3.3,4, \\
4.1, \\
4.4, \\
20.7 \\
\end{array}$ & 0 & 0 & $\begin{array}{l}1.8,2.5, \\
3.5,4.4, \\
5.2\end{array}$ & $\begin{array}{l}0,2.7, \\
28.7, \\
45.7, \\
53.3 \\
\end{array}$ & 0 & 0 & H-lignin & $\begin{array}{l}87-66- \\
1\end{array}$ & Aldrich & $99 \%$ \\
\hline $\begin{array}{l}\mathbf{C 1 8}^{\mathbf{c}} \\
\phi \alpha \uparrow\end{array}$ & 2H-pyran-2,4-dione & 1006 & Pyran & & & $\begin{array}{l}0, \quad 0, \\
5169, \\
8391.6, \\
9232.3\end{array}$ & $\begin{array}{l}0, \\
5315.7, \\
5395.4, \\
7112.7, \\
8656.5 \\
\end{array}$ & $\begin{array}{l}0, \\
1822.5, \\
3013.1, \\
4571, \\
7670.6 \\
\end{array}$ & $\begin{array}{l}0, \\
200.4, \\
520.7, \\
730, \\
983.2 \\
\end{array}$ & $\begin{array}{l}50.1, \\
327.2, \\
1218.5, \\
1818.4, \\
9232.3 \\
\end{array}$ & $\begin{array}{l}382.1, \\
812, \\
954.5, \\
1453.6, \\
3805.8 \\
\end{array}$ & $\begin{array}{l}69.4, \\
595, \\
1137.7, \\
1996.4, \\
6796.4 \\
\end{array}$ & $\begin{array}{l}0, \quad 0, \\
497.8, \\
524.3, \\
720.2\end{array}$ & Cellulose & & & \\
\hline $\begin{array}{l}\mathbf{C 1 9}^{\mathbf{b}} \\
\# \dagger \varnothing \downarrow \uparrow\end{array}$ & $\begin{array}{l}\text { 2-hydroxy-3- } \\
\text { methyl-2- } \\
\text { cyclopenten-1-one }\end{array}$ & 1035 & Ketone & $\begin{array}{l}1036^{*} \\
(1000- \\
1036)\end{array}$ & $\begin{array}{l}1838^{*} \\
(1824- \\
1839)\end{array}$ & $\begin{array}{l}0,0,1.5 \\
3.2,5.5\end{array}$ & 0 & 0 & 0 & $\begin{array}{l}0,3,4.6, \\
5.3,6.2\end{array}$ & 0 & 0 & 0 & & & & \\
\hline $\begin{array}{l}\mathbf{C 2 0}^{\mathbf{a}} \\
\# \uparrow \varnothing \uparrow\end{array}$ & $\begin{array}{l}\text { 2-hydroxy- } \\
\text { benzaldehyde }\end{array}$ & 1048 & Phenol & $\begin{array}{l}1044 * * \\
(1013- \\
1074) \\
\end{array}$ & $\begin{array}{l}1699 * * \\
(1628- \\
1702) \\
\end{array}$ & $\begin{array}{l}0,0,0 \\
0,4.6\end{array}$ & 0 & 0 & 0 & $\begin{array}{l}0,1.4,6, \\
6.6,13.5\end{array}$ & 0 & 0 & 0 & G-lignin & $\begin{array}{l}90-02- \\
8\end{array}$ & $\begin{array}{l}\text { Alfa } \\
\text { Aesar }\end{array}$ & $99 \%$ \\
\hline $\begin{array}{l}\text { C21 } \\
\emptyset \notin \not \downarrow \\
a \uparrow\end{array}$ & 2-methyl-phenol & 1061 & Phenol & $\begin{array}{l}1052 * \\
(1029- \\
1068)\end{array}$ & $\begin{array}{l}1022^{*} \\
(1995- \\
2022)\end{array}$ & $\begin{array}{l}0,1.1,0 \\
3.2,9.5\end{array}$ & $\begin{array}{l}1.7, \\
4.8, \\
5.7, \\
13.9 \\
130.3 \\
\end{array}$ & $\begin{array}{l}0,1.9, \\
3.2, \\
37.1, \\
102.5\end{array}$ & 0 & $\begin{array}{lr}0, & 0.3, \\
1.5, & 4.3, \\
19 & \end{array}$ & $\begin{array}{l}0, \quad 0, \\
26.8, \\
77.9, \\
134.8\end{array}$ & $\begin{array}{l}0,9.6, \\
11.3, \\
21, \\
83.9\end{array}$ & 0 & & & & \\
\hline $\begin{array}{l}\mathbf{C 2 2}^{\mathbf{c}} \\
\# \uparrow \emptyset \uparrow\end{array}$ & $\begin{array}{l}\text { 1-acetyl-(1H)- } \\
\text { imidazole }\end{array}$ & 1065 & Imidazole & $1054 * *$ & & $\begin{array}{l}0,0,0 \\
8.7,16.2\end{array}$ & 0 & 0 & 0 & $\begin{array}{l}0,10.2, \\
12.2, \\
15.6, \\
17.4\end{array}$ & 0 & 0 & 0 & & & & \\
\hline${\mathrm{C} 23^{\mathrm{c}}}$ & $\gamma$-terpinene & 1068 & Terpenoid & $\begin{array}{l}1065^{*} \\
(1031- \\
1082) \\
\end{array}$ & $\begin{array}{l}1239 * \\
(1200- \\
1274) \\
\end{array}$ & 0 & 0 & 0 & 0 & $\begin{array}{l}0,0.5,3, \\
9.2,12.4\end{array}$ & 0 & 0 & 0 & & & & \\
\hline
\end{tabular}




\begin{tabular}{|c|c|c|c|c|c|c|c|c|c|c|c|c|c|c|c|c|c|}
\hline \multirow{3}{*}{ ID } & \multirow{3}{*}{ Compound } & \multirow{3}{*}{ 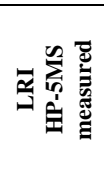 } & \multirow{3}{*}{$\begin{array}{l}\text { Functional } \\
\text { group }\end{array}$} & \multirow{3}{*}{ 象密 } & \multirow{3}{*}{ 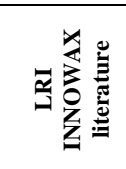 } & \multicolumn{8}{|c|}{ Emission rates $(\mu \mathrm{g} / \mathrm{gs}))$} & \multirow{3}{*}{ Products of } & \multicolumn{3}{|c|}{$\begin{array}{c}\text { Authentic standard } \\
\text { factors }\end{array}$} \\
\hline & & & & & & \multicolumn{4}{|c|}{$250^{\circ} \mathrm{C}$} & \multicolumn{4}{|c|}{$300^{\circ} \mathrm{C}$} & & \multirow{2}{*}{$\begin{array}{l}\text { CAS } \\
\text { No. }\end{array}$} & \multirow{2}{*}{$\underset{\text { ny }}{\text { Compa- }}$} & \multirow{2}{*}{$\begin{array}{l}\text { Pu- } \\
\text { rity }\end{array}$} \\
\hline & & & & & & WSP1 & WSP2 & WSP3 & WSP4 & WSP1 & WSP2 & WSP3 & WSP4 & & & & \\
\hline $\begin{array}{l}\mathbf{C 2 4}^{\mathbf{b}} \\
\# ¥ \phi^{\uparrow}\end{array}$ & 4-methyl-phenol & 1088 & Phenol & $\begin{array}{l}1085^{*} \\
(1051- \\
0198)\end{array}$ & $\begin{array}{l}2076^{* *} \\
(2037- \\
2117)\end{array}$ & 0 & 0 & $\begin{array}{l}0,0,0, \\
24.5, \\
26.5\end{array}$ & 0 & 0 & 0 & $\begin{array}{l}97.1, \\
135.4, \\
183.2, \\
190.7, \\
1955.6\end{array}$ & 0 & & & & \\
\hline $\begin{array}{l}\mathbf{C 2 5}^{\mathbf{a}} \\
\# \emptyset \phi \nsubseteq \downarrow \\
\# ¥ \emptyset \uparrow\end{array}$ & $\begin{array}{l}\text { 2-methoxy-phenol, } \\
\text { (guaiacol) }\end{array}$ & 1094 & Guaiacol & $1105^{* * *}$ & $1880 * * *$ & $\begin{array}{l}6639.8, \\
736.7, \\
771.7, \\
772, \\
838.9\end{array}$ & $\begin{array}{l}1879.4, \\
2027.3, \\
2056.2, \\
2117.4, \\
2372.4\end{array}$ & $\begin{array}{l}190.5, \\
294.6, \\
745.8, \\
945.5, \\
2578.9\end{array}$ & $\begin{array}{l}32, \\
138.1, \\
146.2, \\
395, \\
424.4\end{array}$ & $\begin{array}{l}838.9, \\
1010.8, \\
1023.4, \\
1045.9 \\
1058.9\end{array}$ & $\begin{array}{l}2934.5, \\
3067.5, \\
3087.2, \\
3129.2, \\
3211.4\end{array}$ & $\begin{array}{l}339.2, \\
716.4, \\
832, \\
2026, \\
2270\end{array}$ & $\begin{array}{l}237.6, \\
378.4, \\
876.2, \\
1283.2, \\
1867.6\end{array}$ & G-lignin & $\begin{array}{l}90-05- \\
1\end{array}$ & Fluka & $98 \%$ \\
\hline $\mathrm{C26}^{\mathrm{a}}$ & $\begin{array}{l}\text { 2,2-dimethyl-1,3- } \\
\text { cyclopentanedione }\end{array}$ & & Ketone & & & 0 & 0 & 0 & 0 & $\begin{array}{ll}0, & 0.5, \\
2.8, & 4.2, \\
5.8 & \end{array}$ & 0 & 0 & 0 & & & & \\
\hline $\mathrm{C27}^{\mathrm{a}}$ & $\begin{array}{l}\text { hydrazide benzoic } \\
\text { acid }\end{array}$ & & acid & & & $\begin{array}{l}0,0,0 \\
0,3\end{array}$ & 0 & 0 & 0 & $\begin{array}{l}0, \quad 1.1, \\
6.4, \\
18.8, \\
25.7\end{array}$ & 0 & 0 & 0 & & & & \\
\hline $\begin{array}{l}\mathbf{C 2 8}^{\mathrm{c}} \\
\emptyset_{\notin} \downarrow\end{array}$ & levoglucosenone & 1119 & Anhydrosugar & $1123 * * *$ & & $\begin{array}{l}0,0,0.1 \\
0.3,1.9\end{array}$ & $\begin{array}{l}0.1, \\
0.5, \\
0.5, \\
0.8,9.7\end{array}$ & $\begin{array}{l}0,0.1, \\
0.6, \\
2.1,3.6\end{array}$ & 0 & $\begin{array}{l}0.4,2.8, \\
6.1,8.7, \\
10.4\end{array}$ & $\begin{array}{l}1.4, \\
2.5,3, \\
7,8\end{array}$ & $\begin{array}{l}0.6, \\
2.1, \\
3.4, \\
5.2, \\
13.8\end{array}$ & $\begin{array}{l}0.3, \\
0.3, \\
0.6, \\
1.1,5.2\end{array}$ & $\begin{array}{l}\text { Cellulose } \quad+ \\
\text { Hemi- } \\
\text { cellulose }\end{array}$ & & & \\
\hline $\begin{array}{l}\mathbf{C 2 9}^{\mathbf{b}} \\
\# \dagger \downarrow\end{array}$ & $\begin{array}{l}\text { 2-methoxy-3- } \\
\text { methyl-phenol }\end{array}$ & 1185 & Guaiacol & $1178^{*}$ & $2021 *$ & $\begin{array}{l}22.6, \\
3.4,4.1, \\
6.9,43.9\end{array}$ & & 0 & 0 & $\begin{array}{l}0,0,1.3 \\
4.4,6.9\end{array}$ & 0 & 0 & 0 & & & & \\
\hline $\begin{array}{l}\mathbf{C 3 0}^{\mathbf{a}} \\
\varnothing \notin \alpha \downarrow\end{array}$ & 5-methylguaiacol & 1196 & Guaiacol & $\begin{array}{l}1194 * * \\
(1177- \\
1202)\end{array}$ & $1789^{* * *}$ & $\begin{array}{l}1.53 \\
1.7,1.8 \\
1.8,1.9\end{array}$ & $\begin{array}{l}0.7, \\
0.8, \\
0.9, \\
1.2,3.1\end{array}$ & $\begin{array}{l}0.4, \\
0.5, \\
0.5, \\
1.8,6.6\end{array}$ & 0 & $\begin{array}{l}1.9,2.5, \\
2.6,2.6, \\
2.7\end{array}$ & $\begin{array}{l}0.5, \\
1.2, \\
4.1, \\
8.9, \\
15.6\end{array}$ & $\begin{array}{l}0.5, \\
0.9, \\
0.9, \\
1.6,4.7\end{array}$ & 0 & G-lignin & $\begin{array}{l}1195- \\
09-1\end{array}$ & Aldrich & $98 \%$ \\
\hline $\begin{array}{l}\mathbf{C 3 1}^{\mathbf{b}} \\
\# \dagger \varnothing ¥ \phi \downarrow\end{array}$ & 4-ethyl-guaiacol & 1285 & Guaiacol & $\begin{array}{l}1282^{*} \\
(1243- \\
1285)\end{array}$ & $\begin{array}{l}2055^{*} \\
(2002- \\
2055)\end{array}$ & $\begin{array}{ll}0.5, & 0.6 \\
0, & 0.6 \\
0.7 & \end{array}$ & $\begin{array}{l}0.1, \\
0.1, \\
0.1, \\
0.1,0.1\end{array}$ & 0 & 0 & $\begin{array}{ll}0.7, & 0.9, \\
0.9, & 0.9, \\
0.9\end{array}$ & $\begin{array}{l}0.1, \\
0.1, \\
0.1, \\
0.1,0.1\end{array}$ & 0 & 0 & G-lignin & & & \\
\hline $\mathrm{C32}^{\mathrm{b}}$ & $\begin{array}{l}\text { 1,2,3,4-tetrahydro- } \\
\text { 1,5,7-trimethyl- } \\
\text { naphthalene }\end{array}$ & 1289 & Naphthalene & $1310^{*}$ & $1462 * *$ & 0 & 0 & $\begin{array}{l}0,0.1, \\
0.2, \\
0.4,0.7\end{array}$ & 0 & 0 & 0 & $\begin{array}{l}0.2, \\
0.4, \\
0.5, \\
1.6,1.6\end{array}$ & 0 & Extractives & & & \\
\hline
\end{tabular}




\begin{tabular}{|c|c|c|c|c|c|c|c|c|c|c|c|c|c|c|c|c|c|}
\hline \multirow{3}{*}{ ID } & \multirow{3}{*}{ Compound } & \multirow{3}{*}{ 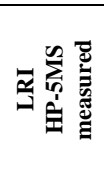 } & \multirow{3}{*}{$\begin{array}{l}\text { Functional } \\
\text { group }\end{array}$} & \multirow{3}{*}{ 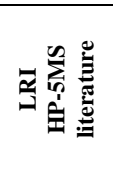 } & \multirow{3}{*}{ 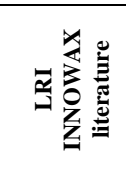 } & \multicolumn{8}{|c|}{ Emission rates $(\mu \mathrm{g} / \mathrm{gs}))$} & \multirow{3}{*}{ Products of } & \multicolumn{3}{|c|}{$\begin{array}{c}\text { Authentic standard } \\
\text { factors }\end{array}$} \\
\hline & & & & & & \multicolumn{4}{|c|}{$250^{\circ} \mathrm{C}$} & \multicolumn{4}{|c|}{$300^{\circ} \mathrm{C}$} & & \multirow{2}{*}{$\begin{array}{l}\text { CAS } \\
\text { No. }\end{array}$} & \multirow{2}{*}{$\underset{\text { ny }}{\text { Compa- }}$} & \multirow{2}{*}{$\begin{array}{l}\mathrm{Pu}- \\
\text { rity }\end{array}$} \\
\hline & & & & & & WSP1 & WSP2 & WSP3 & WSP4 & WSP1 & WSP2 & WSP3 & WSP4 & & & & \\
\hline $\begin{array}{l}\mathbf{C 3 3}^{\mathbf{b}} \\
\# \dagger \varnothing ¥ \not \downarrow \downarrow\end{array}$ & $\begin{array}{l}\text { 2-methoxy-4- } \\
\text { vinylphenol }\end{array}$ & 1318 & Guaiacol & $\begin{array}{l}1313 * * \\
(1272- \\
1313)\end{array}$ & $\begin{array}{l}2138 * * \\
(2138- \\
2205)\end{array}$ & $\begin{array}{l}\text { 197.6, } \\
202.3, \\
225.9, \\
347.1, \\
403.2\end{array}$ & $\begin{array}{l}13.4, \\
22.3, \\
33.9, \\
40.6, \\
64.8\end{array}$ & 0 & 0 & $\begin{array}{l}12.8, \\
51.1, \\
156.7, \\
176.5, \\
347.1\end{array}$ & $\begin{array}{l}6.5, \\
87.4 \\
119.5 \\
121.8 \\
242\end{array}$ & 0 & 0 & G-lignin & $\begin{array}{l}7786- \\
61-0\end{array}$ & SAFC & $98 \%$ \\
\hline $\begin{array}{l}\mathbf{C 3 4}^{\mathbf{b}} \\
\# ¥ \not \downarrow \downarrow\end{array}$ & $\begin{array}{l}\text { 3-methoxy-5- } \\
\text { methylphenol }\end{array}$ & 1330 & Guaiacol & $\begin{array}{l}1317 * * \\
(1317- \\
1342)\end{array}$ & $\begin{array}{l}2524 * * \\
(2524- \\
2535)\end{array}$ & 0 & 0 & $\begin{array}{l}0.01, \\
0.02, \\
0.02, \\
0.03, \\
0.04\end{array}$ & 0 & 0 & 0 & 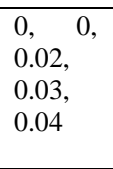 & 0 & & & & \\
\hline $\mathrm{C35}^{\mathrm{a}}$ & $\begin{array}{l}\text { 1,2-dihydro-1,1,6- } \\
\text { trimethyl- } \\
\text { naphthalene }\end{array}$ & 1353 & Naphthalene & $\begin{array}{l}1332 * * \\
(1313- \\
1332) \\
\end{array}$ & $\begin{array}{l}1724 * \\
(1712- \\
1724)\end{array}$ & $\begin{array}{l}0,0,0 \\
0.6,1.1\end{array}$ & 0 & 0 & 0 & 0 & 0 & 0 & 0 & & & & \\
\hline $\begin{array}{l}\mathbf{C 3 6}^{\mathbf{a}} \\
\phi \not a \downarrow \\
\varnothing \uparrow\end{array}$ & $\begin{array}{l}\text { 2,6-dimethoxy- } \\
\text { phenol, (syringol) }\end{array}$ & 1357 & Syringol & $\begin{array}{l}1347 * * \\
(1304- \\
1347)\end{array}$ & $\begin{array}{l}2269 * * \\
(2251- \\
2307)\end{array}$ & $\begin{array}{l}0,0,4.6 \\
10.8 \\
16.2\end{array}$ & $\begin{array}{l}0.4, \\
0.5, \\
0.5, \\
0.9,1.4\end{array}$ & $\begin{array}{l}0.4, \\
0.7, \\
3.4, \\
3.5,3.8\end{array}$ & $\begin{array}{l}0,0,0 \\
0.3 \\
1.3\end{array}$ & $\begin{array}{l}1.3,4.2, \\
20.3, \\
40.4,60\end{array}$ & $\begin{array}{l}1.2, \\
3.8, \\
4.5, \\
8.4, \\
37.5\end{array}$ & $\begin{array}{l}0.7, \quad 1, \\
1.6, \\
24.3, \\
39.5\end{array}$ & $\begin{array}{l}0,0.3, \\
0.9, \\
6.3, \\
25.3\end{array}$ & S-lignin & $\begin{array}{l}91-10- \\
1\end{array}$ & Aldrich & $98 \%$ \\
\hline $\begin{array}{l}\mathbf{C 3 7}^{\mathrm{a}} \\
\dagger \varnothing \notin \emptyset \downarrow \\
\# \notin \uparrow\end{array}$ & vanillin & 1406 & Guaiacol & $\begin{array}{l}1403 * * \\
(1348- \\
1403)\end{array}$ & $\begin{array}{l}2566^{* * *} \\
(2540- \\
2610)\end{array}$ & $\begin{array}{l}0, \quad 0.3, \\
8.6, \\
31.9, \\
86.4\end{array}$ & $\begin{array}{l}0, \quad 0.3, \\
0.4, \\
0.5,0.9\end{array}$ & $\begin{array}{l}0,0.2, \\
1.1, \\
1.4,2.4\end{array}$ & 0 & $\begin{array}{l}0, \quad 5.6, \\
93.4, \\
135.2, \\
292.9\end{array}$ & $\begin{array}{l}0.1, \\
0.2, \\
0.3, \\
0.6,5.7\end{array}$ & $\begin{array}{l}0, \quad 0, \\
0.3, \\
2.7,7.3\end{array}$ & 0 & G-lignin & $\begin{array}{l}121- \\
33-5\end{array}$ & Aldrich & $99 \%$ \\
\hline $\mathrm{C38}^{\mathrm{a}}$ & $\begin{array}{l}\text { 2,6-dimethyl- } \\
\text { naphthalene }\end{array}$ & 1429 & Naphthalene & $\begin{array}{l}1425^{*} \\
(1409- \\
1425)\end{array}$ & $\begin{array}{l}2038^{*} \\
(2012- \\
2038)\end{array}$ & $\begin{array}{l}0,0,0 \\
9.2,16.1\end{array}$ & 0 & 0 & 0 & 0 & 0 & 0 & 0 & $\begin{array}{l}\text { Break down } \\
\text { product of ST }\end{array}$ & $\begin{array}{l}581- \\
42-0\end{array}$ & Aldrich & $98 \%$ \\
\hline $\mathbf{C 3 9}^{\mathrm{b}}$ & $\begin{array}{l}\text { 1,5-dimethyl- } \\
\text { naphthalene }\end{array}$ & 1429 & Naphthalene & $\begin{array}{l}1425^{*} \\
(1325- \\
1450)\end{array}$ & $2048 *$ & $\begin{array}{ll}0, & 0.1, \\
0.2, & 0.2, \\
0.4 & \end{array}$ & 0 & 0 & 0 & $\begin{array}{l}0,0,0.1 \\
0.8,2.1\end{array}$ & 0 & 0 & 0 & & & & \\
\hline $\mathrm{C40}^{\mathrm{a}}$ & trans-isoeugenol & 1455 & Guaiacol & $\begin{array}{l}1410^{*} \\
(1410- \\
1499)\end{array}$ & & $\begin{array}{ll}0, & 0, \\
31.8, & \\
76.2, & \\
142.8 & \end{array}$ & 0 & 0 & 0 & $\begin{array}{l}3.1, \\
22.7, \\
93.4, \\
249.1, \\
345.7\end{array}$ & 0 & 0 & 0 & $\begin{array}{l}\text { G-lignin } \\
\text { (Phenolic } \\
\text { extractive) }\end{array}$ & $\begin{array}{l}5932- \\
68-3\end{array}$ & Aldrich & $98 \%$ \\
\hline $\begin{array}{l}\text { C41 }^{\mathbf{a}} \\
\# \uparrow\end{array}$ & $\begin{array}{l}\text { 3-hydroxy-4- } \\
\text { methoxybenzoic } \\
\text { acid }\end{array}$ & & Acid & & & 0 & 0 & $\begin{array}{l}0,0.3, \\
0.4, \\
0.7,1.1\end{array}$ & 0 & 0 & 0 & $\begin{array}{l}0.2, \\
0.8, \\
2.8, \\
5.4, \\
12.6\end{array}$ & 0 & & & & \\
\hline
\end{tabular}




\begin{tabular}{|c|c|c|c|c|c|c|c|c|c|c|c|c|c|c|c|c|c|}
\hline \multirow{3}{*}{ ID } & \multirow{3}{*}{ Compound } & \multirow{3}{*}{ 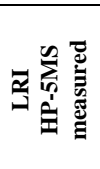 } & \multirow{3}{*}{$\begin{array}{l}\text { Functional } \\
\text { group }\end{array}$} & \multirow{3}{*}{ 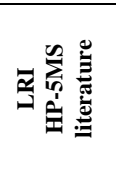 } & \multirow{3}{*}{ 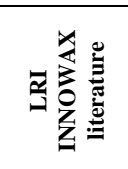 } & \multicolumn{8}{|c|}{ Emission rates $(\mu \mathrm{g} / \mathrm{g} * \mathrm{~s}))$} & \multirow{3}{*}{ Products of } & \multicolumn{3}{|c|}{$\begin{array}{c}\text { Authentic standard } \\
\text { factors }\end{array}$} \\
\hline & & & & & & \multicolumn{4}{|c|}{$250^{\circ} \mathrm{C}$} & \multicolumn{4}{|c|}{$300^{\circ} \mathrm{C}$} & & \multirow{2}{*}{$\begin{array}{l}\text { CAS } \\
\text { No. }\end{array}$} & \multirow{2}{*}{$\begin{array}{c}\text { Compa- } \\
\text { ny }\end{array}$} & \multirow{2}{*}{$\begin{array}{l}\text { Pu- } \\
\text { rity }\end{array}$} \\
\hline & & & & & & WSP1 & WSP2 & WSP3 & WSP4 & WSP1 & WSP2 & WSP3 & WSP4 & & & & \\
\hline $\mathrm{C}^{2} 2^{\mathrm{a}}$ & $\begin{array}{l}\text { a-caryophyllene } \\
\text { (a-humulene) }\end{array}$ & 1461 & Terpenoid & $\begin{array}{l}1456^{*} \\
(1417- \\
1469)\end{array}$ & $\begin{array}{l}1705^{*} \\
(1624- \\
1705)\end{array}$ & $\begin{array}{l}0,0,0 \\
4.7,8.1\end{array}$ & 0 & 0 & 0 & $\begin{array}{l}0,0,0 \\
1.7,4.6\end{array}$ & 0 & 0 & 0 & ST extractive & $\begin{array}{l}\text { 6753- } \\
98-6\end{array}$ & Aldrich & $96 \%$ \\
\hline $\begin{array}{l}\mathbf{C 4 3 ^ { b }} \\
\# \dagger \downarrow\end{array}$ & aromadendrene & 1469 & Terpenoid & $1455^{* * *}$ & $\begin{array}{l}1637^{* * *} \\
(1622- \\
1637)\end{array}$ & $\begin{array}{ll}0, & 0.1, \\
0.3, & 3.7, \\
7 & \\
\end{array}$ & 0 & 0 & 0 & $\begin{array}{l}0,0,0.2 \\
2.3,5.4\end{array}$ & 0 & 0 & 0 & ST extractive & $\begin{array}{l}489- \\
39-4\end{array}$ & Aldrich & $97 \%$ \\
\hline $\mathbf{C 4 4}^{\mathrm{b}}$ & $\begin{array}{l}\text { cadina-1(10),6,8- } \\
\text { triene }\end{array}$ & 1525 & Terpenoid & $\begin{array}{l}1519 * * \\
(1512- \\
1519) \\
\end{array}$ & $\begin{array}{l}1834 * * \\
(1807- \\
1876)\end{array}$ & $\begin{array}{l}0,0,0 \\
0.2,0.3\end{array}$ & 0 & 0 & 0 & $\begin{array}{l}0,0,0 \\
0.4,0.9\end{array}$ & 0 & 0 & 0 & & & & \\
\hline${\mathrm{C} 45^{\mathrm{c}}}^{\mathrm{s}}$ & $\begin{array}{l}\text { 3-(2-naphthyl)-1- } \\
\text { butene }\end{array}$ & 1530 & Naphthalene & & & 0 & 0 & $\begin{array}{l}0,0,0, \\
0,0.1\end{array}$ & 0 & 0 & 0 & $\begin{array}{l}0.1, \\
0.2, \\
0.6, \\
1.2,3.1\end{array}$ & 0 & & & & \\
\hline $\mathrm{C}^{4} 6^{\mathrm{b}}$ & $\delta$-cadinene & 1530 & Terpenoid & $1520^{* * *}$ & $1774 *$ & $\begin{array}{l}0, \quad 0, \\
87.2, \\
45710.8, \\
86998.2\end{array}$ & 0 & 0 & 0 & $\begin{array}{l}0,0,0, \\
27997.9, \\
72491.7\end{array}$ & 0 & 0 & 0 & $\begin{array}{l}\text { ST extractive } \\
\text { (cadalenes) }\end{array}$ & $\begin{array}{l}1460- \\
97-5\end{array}$ & $\begin{array}{l}\text { BOC } \\
\text { sciences }\end{array}$ & $99 \%$ \\
\hline $\mathrm{C}_{4} 7^{\mathrm{a}}$ & $\begin{array}{l}\text { 4-hydroxy-3- } \\
\text { methoxy- } \\
\text { benzoicacid } \\
\text { methylester } \\
\end{array}$ & 1535 & Guaiacol & $1540^{* * *}$ & & $\begin{array}{l}14.2, \\
15.2,38, \\
985.8, \\
1855.5\end{array}$ & 0 & 0 & 0 & $\begin{array}{l}3.5,4.4, \\
22.1, \\
637.7 \\
1571.7\end{array}$ & 0 & 0 & 0 & $\begin{array}{l}\text { G- } \\
\text { lignin(Phenolic } \\
\text { extractive ) }\end{array}$ & $\begin{array}{l}15964- \\
80-4\end{array}$ & Aldrich & $98 \%$ \\
\hline $\mathrm{C48}^{\mathrm{c}}$ & $\alpha$-calacorene & 1551 & Terpenoid & $1527^{* * * *}$ & & $\begin{array}{l}0.3,0.4 \\
1,1,1.8\end{array}$ & 0 & 0 & 0 & $\begin{array}{l}0,0,0.5 \\
2,4.1\end{array}$ & 0 & 0 & 0 & $\begin{array}{l}\text { ST extractive } \\
\text { (cadalenes) }\end{array}$ & & & \\
\hline${\mathrm{C} 49^{\mathrm{c}}}^{\mathrm{C}}$ & unidentified & 1572 & Naphthalene & & & $\begin{array}{ll}0.2, & 0.2 \\
0.5, & 1.8 \\
3.6 & \end{array}$ & 0 & 0 & 0 & $\begin{array}{l}0,0,0.3 \\
1.1,2.3\end{array}$ & 0 & 0 & 0 & & & & \\
\hline $\mathrm{C50}^{\mathrm{c}}$ & unidentified & 1592 & Guaiacol & & & $\begin{array}{ll}0.4, & 0.4, \\
0.5, & 0.9, \\
1\end{array}$ & 0 & 0 & 0 & $\begin{array}{ll}0, & 0.1, \\
0.6, & 0.8, \\
0.9 & \end{array}$ & 0 & 0 & 0 & & & & \\
\hline $\mathrm{C}^{2} 1^{\mathrm{c}}$ & unidentified & 1625 & Terpenoid & & & $\begin{array}{l}0.3,0.6, \\
0.7,0.9, \\
1.3\end{array}$ & 0 & 0 & 0 & $\begin{array}{ll}0, & 0.1, \\
0.4, & 0.8, \\
1 & \end{array}$ & 0 & 0 & 0 & & & & \\
\hline $\mathbf{C 5 2}^{\mathrm{b}}$ & tau-muurolol & 1650 & Terpenoid & $\begin{array}{l}1633^{* *} \\
(1608- \\
1649) \\
\end{array}$ & $\begin{array}{l}2179 * * \\
(2143 \quad- \\
2209)\end{array}$ & $\begin{array}{l}0.7,0.8, \\
1.1,1.7, \\
2.4\end{array}$ & 0 & 0 & 0 & $\begin{array}{l}0,0,0 \\
1.8,3.5\end{array}$ & 0 & 0 & 0 & & & & \\
\hline $\mathbf{C 5 3}^{\mathrm{c}}$ & $\begin{array}{l}\text { 4-hydroxy-3,5- } \\
\text { dimethoxy- } \\
\text { benzaldehyde }\end{array}$ & 1663 & Terpenoid & $1663^{* * *}$ & & $\begin{array}{ll}0, & 0.5 \\
0.8, & 1.6, \\
1.7 & \\
\end{array}$ & 0 & 0 & 0 & $\begin{array}{l}0,0,0.5 \\
1.4,1.8\end{array}$ & 0 & 0 & 0 & $\begin{array}{l}\text { S- } \\
\text { lignin(Phenolic } \\
\text { extractive) }\end{array}$ & $\begin{array}{l}134- \\
96-3\end{array}$ & Aldrich & $98 \%$ \\
\hline
\end{tabular}




\begin{tabular}{|c|c|c|c|c|c|c|c|c|c|c|c|c|c|c|c|c|c|}
\hline \multirow{3}{*}{ ID } & \multirow{3}{*}{ Compound } & \multirow{3}{*}{ 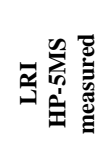 } & \multirow{3}{*}{$\begin{array}{l}\text { Functional } \\
\text { group }\end{array}$} & \multirow{3}{*}{ 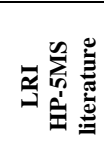 } & \multirow{3}{*}{ 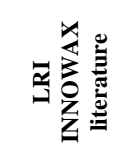 } & \multicolumn{8}{|c|}{ Emission rates $(\mu \mathrm{g} / \mathrm{g} * \mathrm{~s}))$} & \multirow{3}{*}{ Products of } & \multicolumn{3}{|c|}{$\begin{array}{l}\text { Authentic standard } \\
\text { factors }\end{array}$} \\
\hline & & & & & & \multicolumn{4}{|c|}{$250^{\circ} \mathrm{C}$} & \multicolumn{4}{|c|}{$300^{\circ} \mathrm{C}$} & & \multirow{2}{*}{$\begin{array}{l}\text { CAS } \\
\text { No. }\end{array}$} & \multirow{2}{*}{$\begin{array}{c}\text { Compa- } \\
\text { ny }\end{array}$} & \multirow{2}{*}{$\begin{array}{l}\text { Pu- } \\
\text { rity }\end{array}$} \\
\hline & & & & & & WSP1 & WSP2 & WSP3 & WSP4 & WSP1 & WSP2 & WSP3 & WSP4 & & & & \\
\hline $\mathrm{C5}^{\mathrm{b}}$ & cadalene & 1684 & Terpenoid & $\begin{array}{l}1684 * \\
(1645- \\
1684)\end{array}$ & $\begin{array}{l}2242 * \\
(2196- \\
2242)\end{array}$ & $\begin{array}{l}4.1,7.3, \\
9.4, \\
14.6, \\
14.8\end{array}$ & 0 & 0 & 0 & $\begin{array}{l}0.9,1.8, \\
6.1, \\
13.4, \\
18.62\end{array}$ & 0 & 0 & 0 & $\begin{array}{l}\text { ST extractive } \\
\text { (cadalenes) }\end{array}$ & & & \\
\hline $\mathrm{C55}^{\mathrm{b}}$ & $\begin{array}{l}\text { 10-nor-calamenen- } \\
\text { 10-one }\end{array}$ & 1714 & Terpenoid & $\begin{array}{l}1700 * * \\
(1671- \\
1700)\end{array}$ & $2419^{* * *}$ & $\begin{array}{l}2.7,9.6, \\
13.7, \\
15.6, \\
16.6\end{array}$ & 0 & 0 & 0 & $\begin{array}{l}1.8, \quad 5, \\
6.4,7.9, \\
13.7\end{array}$ & 0 & 0 & 0 & $\begin{array}{l}\text { Oxidized } \\
\text { (cadalenes) }\end{array}$ & & & \\
\hline
\end{tabular}

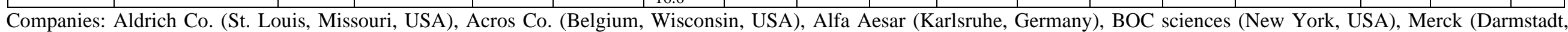
Germany), Fluka (Buchs, Switzerland), SAFC Co. (St. Louis, Missouri, USA), SCB Santa Cruz Biotech (Heidelberg, Germany). 